\author{
UNIVERSIDADE DE SÃO PAULO \\ FACULDADE DE FILOSOFIA LETRAS E CIÊNCIAS HUMANAS \\ PROGRAMA DE PÓS-GRADUAÇÃO EM LITERATURA \\ PORTUGUESA
}

LÚCIA MARIA DE SOUZA

\title{
A VIA-CRÚCIS DAS PERSONAGENS NA DESCONSTRUÇÃO E RECONSTRUÇÃO DO ESPAÇO E DO TEMPO EM ENSAIO ŞOBRE A CEGUEIRA
}

SÃO PAULO

2010 


\title{
LÚCIA MARIA DE SOUZA
}

\section{A VIA-CRÚCIS DAS PERSONAGENS NA DESCONSTRUÇÃO E RECONSTRUÇÃO DO ESPAÇO E DO TEMPO EM ENSAIO SOBRE A CEGUEIRA}

\begin{abstract}
Dissertação apresentada ao Programa de Pós-Graduação em Literatura Portuguesa do Departamento de Letras Clássicas e Vernáculas da Faculdade de Filosofia, Letras e Ciências Humanas da Universidade de São Paulo para obtenção do título de Mestre em Literatura Portuguesa.
\end{abstract}

Orientadora: Profa. Dra. Raquel de Sousa Ribeiro

São Paulo

2010 
A Raquel de Sousa Ribeiro, com todo meu carinho, respeito, gratidão e admiração, dedico este trabalho. 


\section{Agradecimentos}

À Professora Doutora Raquel de Souza Ribeiro, pela orientação indispensada durante os três anos da elaboração desse trabalho, por aprender muito com sua experiência e paciência. Agradeço a contribuição e condução da pesquisa e por ter ouvido as mais diversas dúvidas que surgiram ao longo do trajeto até chegar aqui.

À Secretaria Estadual de Educação do Estado de São Paulo pela bolsa mestrado concedida, o que imensamente contribuiu para chegar a etapa final desse trabalho.

À Professora Doutora Lílian Lopondo, da Universidade de São Paulo, e à Professora Doutora Aurora Gedra Ruiz Alvarez, da Universidade Presbiteriana Mackenzie pela contribuição na banca de qualificação, com suas observações salientes para o resultado final dessa pesquisa.

À Maria Helena Fioravante Peixoto, pela leitura e conversa a respeito de literatura que muito reforçaram o amadurecimento das idéias iniciais desse trabalho.

À Neusa Maria Jorgino Oliveira, pelo apoio e dicas na redação final.

Ao meu esposo Jereni Fernandes de Souza pelas muitas horas concedidas para a elaboração desse trabalho, pelo apoio e incentivo indispensáveis para alcançar os objetivos finais e por ter me acompanhado e torcido pelo meu progresso.

Às minhas preciosidades Juliana Fernandes de Souza e Pedro Lucas Fernandes de Souza, por todo o tempo concedido de suas infâncias para que eu chegasse ao fim dessa empreitada.

Aos meus pais Antônio Silvestre Pereira e Eufrásia Maria Pereira que me ensinaram o caminho da persistência para a concretude dos desafios da vida.

A todos irmãos e demais familiares pelo apoio e força durante esta jornada de trabalho e empenho.

À Deus, pelo dom da vida e a oportunidade de dar um passo ao caminho do conhecimento e da sabedoria. 
Olhar, ver e reparar são maneiras distintas de usar o órgão da vista, cada qual com a sua intensidade própria, até nas degenerações, por exemplo, olhar sem ver, quando uma pessoa se encontra ensimesmada, situação comum nos antigos romances, ou ver e não dar por isso, se os olhos por cansaço ou fastio se defendem de sobrecargas incômodas. Só o reparar pode chegar a ser visão plena, quando num ponto determinado ou sucessivamente a atenção se concentra, o que tanto sucederá por efeito duma deliberação da vontade quanto por uma espécie de estado sinestésico involuntário em que o visto solicita ser visto novamente, assim se passando de uma sensação a outra, retendo, arrastando o olhar, como se a imagem tivesse de produzir-se em dois lugares distintos do cérebro com diferença temporal de um centésimo de segundo, primeiro o sinal simplificado, depois o desenho rigoroso, a definição nítida...

José Saramago

História do Cerco de Lisboa

... cada um de nós vê o mundo com os olhos que tem, e os olhos vêem o que querem, os olhos fazem a diversidade do mundo e fabricam as maravilhas, ainda que sejam de pedra, e altas proas, ainda que sejam de ilusão...

José Saramago

Jangada de Pedra 


\section{Resumo}

O presente trabalho tem como objetivo examinar e refletir a desconstrução e reconstrução dos elementos espaço-temporais em Ensaio sobre a cegueira. $\mathrm{O}$ embasamento teórico desse trabalho, dentre outros, será a concepção de cronotopo apresentada por Mikhail Bakhtin, ao lado de conceitos de "não-lugares" e "lugares antropológicos" de Marc-Augé. As pesquisas de Mircea Eliade serão utilizadas para a reflexão de espaços sagrados e profanos e para o exame dos rituais de passagem ou iniciáticos. Tendo em vista a peregrinação feita grupo das sete personagens que protagonizam a trama estabeleceremos um paralelo com a via-crúcis de Jesus apresentada no texto bíblico que trata de um caminho de sofrimento, dor e morte. O percurso da via-crúcis chega ao fim através da metamorfose ocorrida no interior das personagens e que se estende aos espaços projetando uma possível reconstrução espaço-temporal.

Palavras-chave: espaço-temporal; desconstrução; paralelo; via-crúcis; transformação. 


\begin{abstract}
The present work has as objective to examine and to reflect the desconstruction and reconstruction of the space-secular elements in Ensaio sobre a cegueira. The theoretical basement of this work, amongst others, will be the conception of cronotopo presented by Mikhail Bakhtin, to the side of concepts of "not-places" and "antropológicos places" of Marc Augé. The research of Mircea Eliade will be used for the reflection of sacred and profane spaces and for the examination of the rituals of ticket or iniciáticos. In view of the done peregrination group of the seven personages who carry out the tram we will establish a parallel with the way-crucis of Jesus presented in the Biblical text that deals with a way of suffering, pain and death. The passage of the way-crucis arrives at the end through the occured metamorphosis in the interior of the personages and that a possible reconstruction is extended to the spaces projecting space-time.
\end{abstract}

Key-words: space-time; desconstruction; parallel; way-crucis; transformation. 
Sumário

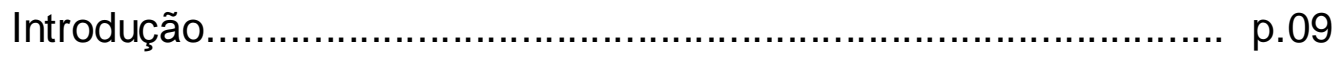

1. Os primeiros passos da via-crúcis - o primeiro encontro ......... p.28

2. O caminho do sofrimento - a segunda etapa da via-crúcis ........ p.56

3. A queda - terceiro percurso da via-crúcis................................ p.83

4. A restauração da visão como sinal de reconstrução espaçotemporal - o fim da via-crúcis................................................ p. p.110

Considerações finais............................................................ p.126

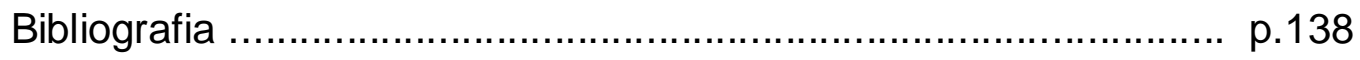


Introdução

(...) o que ali se estará gritando é esta interminável e absurda dor do mundo.

José Saramago

Em Os Cadernos de Lanzarote, espécie de diário, Saramago expressou, com as palavras acima, seu objetivo de criar um romance que suscitasse grandes sentimentos, tais como desilusão, angústia e dor e, ao mesmo tempo, propiciasse uma série de reflexões a respeito das questões humanas na contemporaneidade e suas implicações, fossem elas relacionais, ideológicas ou políticas.

De fato, refletir sobre a questão das relações humanas e suas interferências na sociedade é um convite que Ensaio sobre a cegueira faz ao leitor, não só pela ironia provocadora do romance e pelo seu estilo irreverente (pelo uso não convencional da pontuação, por exemplo), mas também pelo ambiente em que a ação é contextualizada - um panorama violento, que não poupa nenhum tipo de horror.

Quanto às personagens, que não são nomeadas, Saramago diz que procura abstrair todas as limitações de tempo e espaço, como fez em outras obras, e opta por referir-se aos cidadãos por meio das profissões ou outros papéis que exercem na sociedade. É por isso que nos deparamos, durante a narrativa, com um motorista e sua esposa, um ladrão, um oftalmologista e sua esposa, uma prostituta, um adolescente, um idoso, todos eles configurando - juntos - o perfil da cidade, o megaespaço que a todos contém.

Através das ações e traços das personagens é possível fazer uma leitura a respeito da humanidade e seus conflitos, no contexto do mundo contemporâneo. Quanto à violência com que o leitor se depara na obra, o próprio autor relata que não se trata da violência cotidianamente retratada em jornais e revistas; não pretende desenvolver um romance policial. A violência que ele aborda e contesta é a violência oriunda de quaisquer manifestações de poder (sejam religiosas, sociais ou ideológicas) ${ }^{1}$.

\footnotetext{
${ }^{1}$ Referência ao Documentário Os tempos de uma memória (2003).
} 
Outro elemento estrutural de relevo em Ensaio sobre a cegueira é o espaço, que, na verdade, não pode ser visto separado do tempo e das personagens.

$\mathrm{Na}$ obra, os espaços se sucedem e vão, gradativamente, deteriorando-se, acompanhando a degradação das personagens. Por exemplo, o espaço do manicômio delineia um dos momentos cruciais desta degradação. Os espaços que se seguem articulam-se a este, parecendo compor, simbolicamente, uma espécie de via-crúcis ${ }^{2}$ pela qual passará o grupo de cegos até recuperar a visão, ao final do romance.

Analisar o romance Ensaio sobre a cegueira requer um estudo voltado aos elementos espaço-temporais, pois é a partir deles que poderemos visualizar o sentido das relações que estabelecem entre si e com as personagens, tornandose os alicerces fundadores da tensão na narrativa. Os espaços apresentados ao longo da trama revelam o processo de degradação humana a que chegam as personagens, ao passarem pelas mais diversas situações de sofrimento, dor, queda e morte.

A este respeito, uma questão desperta nosso interesse nessa análise: a forma como o espaço e o tempo são desconstruídos e reconstruídos, qual a função da degradação espaço-temporal e, consequentemente, da degradação humana no contexto geral desse romance.

No sentido de buscarmos resposta a essa questão, pretendemos examinar os elementos no contexto da peregrinação das personagens, especificamente das sete personagens que compõem o eixo da narrativa, investigando o sentido desta peregrinação e o papel que os espaços desempenham nas metamorfoses operadas no interior delas. Para tanto, trabalharemos com o sentido da via-crúcis no texto bíblico, sobretudo nos evangelhos, que entendemos estabelecer pontos de contato com a narrativa de Ensaio sobre a cegueira, por tratar de um percurso de dor e sofrimento para as personagens de ambos os textos.

Ao narrar a vida de Cristo, o texto bíblico diz que ele veio ao mundo com o propósito de realizar o projeto que Deus estabeleceu para os povos, qual seja,

\footnotetext{
${ }^{2}$ Seguiremos a grafia da palavra via-crúcis conforme o Dicionário Houaiss da Língua Portuguesa.
} 
salvá-los dos pecados: "ele vai salvar o seu povo dos seus pecados" (BÍBLIA SAGRADA, Novo Testamento, 1990. Mateus 1: 21, p. 1239) Cristo tornou-se então o "cordeiro imolado" dado em sacrifício. Daí seu caminho da cruz, carregado de sofrimento, queda e morte, mas também para cumprir uma outra profecia antiga, segundo a qual, após o caminho da dor, ele venceria a morte e ressuscitaria ao terceiro dia (BÍBLIA SAGRADA, Novo Testamento, 1990. Mateus 17: 23, p.1262).

Padovani e Castagnola, em História da Filosofia (1956), expõem o fundamento do conceito da presença de Jesus na Terra:

O Verbo de Deus, encarnando-se, não somente assume a mísera natureza do homem decaído, excluído certamente o mal moral, mas absorve todo o sofrimento humano até à morte e à morte de cruz (...) através da paixão do Verbo e Deus incarnado, Deus manifesta, no mesmo tempo, a sua inefável essencial bondade para com o homem (...). A consequência da ação redentora de Cristo com respeito à humanidade foi integrá-la na ordem sobrenatural, foi-lhe restituída a graça, e foi restabelecido na adoção divina (p.137)

A flagelação de Jesus até sua morte na cruz, segundo os filósofos, não foi um ato cruel por parte de Deus para com Seu Filho. Ao contrário, através de Jesus Deus manifesta seu amor à humanidade, doa seu próprio Filho para a remissão dos pecados. Jesus é o Deus humanado (idem, p. 138), a aliança entre o céu e a terra. Em Jesus, Deus assume o homem frágil e pecador e procura resgatá-lo através do seu sacrifício de morte na cruz. "A cruz, instrumento de suplício infamante, tornou-se para os cristãos o sinal do resgate dos homens por Jesus" (Fouilloux, 1998: 69-70).

Para o teórico russo Mikhail Bakhtin, a pessoa de Jesus deixou um legado na história da humanidade de Deus, a cristologia presente em sua literatura. Segundo Clark e Holquist (1998), trata-se de um exemplo de doação à causa alheia, um constante diálogo entre o "eu" e o "outro". Nas palavras dos pesquisadores:

Para Bakhtin, Cristo é importante não só como um acontecimento na história cósmica da salvação humana do pecado, mas, igualmente, como um evento no desenvolvimento da consciência humana. Esta consciência é 
a consciência da relação do self com o outro. (...) Em Cristo deparamos uma síntese - única em sua profundeza (...). Pela primeira vez surge um eu-para-mim-mesmo, infinitamente aprofundado, ainda assim, não um frio eu-para-mim-mesmo, mas um eu que é ilimitadamente bom para com o outro. (p. 108-109).

Bakhtin encontrou na pessoa de Jesus a imagem do diálogo perfeito entre a consciência do "eu" e a infinita bondade para com o "outro", que ultrapassa o papel de Salvador da humanidade e torna-se um exemplo de doação, de amor e de despojamento de si e abertura ao próximo.

Tendo em vista a vida de Jesus, pretendemos estabelecer um paralelo entre sua missão em redimir os pecados da humanidade e seu despojamento de si, em prol do outro, com o caminho das sete personagens de Ensaio sobre a cegueira, que vivem uma missão semelhante à de Cristo.

Ocorre-nos que, ao peregrinar de um espaço a outro de sofrimento, dor e morte, o grupo conquista a visão após o doloroso caminho pelo qual passou, até encontrar um lugar "sacralizado" e vencer a cegueira. Não só as sete personagens, mas toda a cidade recupera a visão ao fim do penoso percurso: "... pela janela aberta, apesar da altura a que estava o andar, entrava o rumor das vozes alteradas, as ruas deviam estar cheias de gente, a multidão a gritar uma só palavra". (SARAMAGO, 1995, p. 309-310).

Ao passarem pelas mais diversas situações de sofrimento, morte e queda, as sete personagens contribuem para a recuperação da visão de toda a cidade, como um sacrifício através da via-crúcis que a partir das experiências vividas durante a trama estavam, ao que indica a narrativa, preparadas para uma nova vida e para renovar as relações sociais e espaço-temporais que se desestabilizaram conforme a progressão da cegueira branca.

Podemos pensar numa paródia da via-crúcis bíblica, uma vez que o percurso sacrificial ocorre em espaços profanos e dessacralizados (ELIADE, 2001), incluindo-se aqui o espaço da igreja (visto como espaço profanado). Em todos eles - manicômio, casa da rapariga, supermercado e igreja - notamos a presença do estilo carnavalesco e do grotesco (BAKHTIN, 1987), materializado na sujeira, nos destronamentos que ocorrem ao longo da narrativa e na decadência 
generalizada. A cegueira branca proporciona a peregrinação, a via-crúcis das personagens e conseqüentemente a desestruturação espaço-temporal em Ensaio sobre a cegueira.

O termo via-crúcis nos remete à peregrinação dos cristãos pelos lugares por onde passou Jesus, durante seus momentos de dor e angústia, antes de sua condenação e morte.

As peregrinações nesses lugares tiveram início por volta do século VI depois de Cristo. Entretanto, com as dificuldades que os cristãos encontravam para rememorar as passagens dolorosas de Jesus em sua terra, devido à distância e perseguição, em 1686 o então Papa, Inocêncio XI, concedeu às congregações religiosas o direito de fazer o cortejo da via-crúcis nas igrejas. A viacrúcis representa a rota que recorda a paixão de Jesus; em latim: caminho da cruz, estações da cruz, caminho doloroso ${ }^{3}$.

A paixão de Jesus refere-se aos sofrimentos que ele viveu desde sua agonia no Getsemani, até sua morte na cruz, no Gólgota (FOIULLOUX, 1998:188). Nela se inserem todos os episódios que medeiam a Última Ceia e a morte na cruz. O termo paixão provém do latim passionem, do verbo pati, sofrer, que indica sofrimento (idem). Os quatro evangelhos, de Marcos, Lucas, Mateus e João, relatam as provações físicas e morais, pelas quais Cristo passou durante a paixão. Destas, uma das que se representam mais frequentemente, em termos iconográficos, é o Ecce Homo ("Eis o Homem"), momento em que Cristo é apresentado à multidão flagelado, com uma coroa de espinhos, um ramo na mão e coberto apenas com uma clâmide ou capa vermelha.

A prece no jardim do Getsemani, a traição de Judas, o caminho para o calvário, a crucificação, o sorteio da capa que cobria Jesus e Sua morte são outras representações da paixão muito frequentes, ao que nos ocorre as representações mencionadas funcionam como instrumentos da vontade divina no processo da paixão de Jesus, uma vez que sua morte ocorreria independentemente desses instrumentos. Desde a Última Ceia, em que Cristo

\footnotetext{
${ }^{3}$ Artigo de G. Cyprian Alston de la Catholic Encyclopedia, copyright $@ 1913$ por Encyclopedia Press, Inc.
} 
afirma saber que será traído, e durante toda a paixão, Sua atitude perante os sofrimentos e inevitável morte é de aceitação resignada, de forma a cumprir não a sua, mas a vontade de Seu Pai. Na verdade, o Cristianismo sempre considerou a morte de Cristo como o elemento que justificou Sua vinda à Terra, para expiar os pecados da humanidade e a salvar. A Última Ceia aparece como episódio fundamental para a correta percepção da paixão, uma vez que a sua realização é, simbolicamente, o sacrifício de Cristo para bem dos homens.

O lugar destacado que os evangelistas deram à paixão e à morte de Jesus - embora sinal aparente de um fracasso definitivo - compreende-se na perspectiva de sua fé na ressurreição de Cristo, que aparece como o novo cordeiro pascal, como o servo sofredor de que nos fala Isaías (BÍBLIA SAGRADA, Antigo Testamento, 1990. Isaías 52: 113-53), como o Messias esperado, vencedor do mal e da morte (ibidem).

O termo peregrinação orienta-nos para uma caminhada em busca de um lugar melhor, uma espécie de Paraíso perdido. Trata-se de um tempo difícil de "provações", mas ao final existe a recompensa: o encontro desse Paraíso. Segundo o dicionário de símbolos, "A peregrinação se assemelha aos ritos de iniciação: ela se identifica com o mestre escolhido." (CHEVALIER; GHEERBRANDT, 1999, p. 709).

A partir das denominações, nos indagamos: por que então usarmos termos como via-crúcis e peregrinação? Para nós, estes termos levam a ver, no romance em questão, um processo de busca de ressacralização do mundo caótico em que vivem as personagens e, por extensão, um processo de ressacralização da dimensão humana. Isso nos remete à mesma peregrinação vivida pelos povos da Bíblia, os quais, após um longo percurso de sofrimento, dor e morte, buscavam a purificação através dos rituais sagrados e o encontro da terra prometida, bem como a peregrinação de Cristo em seu percurso terrestre, ao cumprir sua missão de redimir os pecados da humanidade, conforme indicam as profecias das antigas Escrituras: "O Filho do Homem irá morrer" (BÍBLIA SAGRADA, Novo Testamento, 1990. Mateus 28). 
O nascimento de um Salvador era esperado pelos judeus, pois eles conheciam as Escrituras, as quais vaticinavam a chegada de um homem que seria - Filho de Deus. Ele se destacaria por Sua bondade e sabedoria. Essas revelações eram conhecidas também pelo Rei Herodes (Rei da Palestina na Época), através dos sacerdotes e doutores da lei, que o informaram que o Messias nasceria em Belém, na Judeia, para cumprir as profecias das Escrituras (BíBlIA SAGRADA, Novo Testamento, 1990. Mateus 2: 1-8, p.1240). O Libertador, a pessoa que traz o socorro esperado. Deus é o salvador por excelência: "Não há outro Deus fora de mim, Deus justo e salvador... Voltai-vos para mim e sereis salvos." (BÍBLIA SAGRADA, Antigo Testamento, 1990. Isaías 45: 21-22).

"Os cristãos também concedem este título a Jesus, o qual liberta seus fiéis da escravidão do pecado, da submissão às forças do mal, do poder da morte: em cada crente morre o homem de pecado e vive um homem novo, graças ao Espírito (BÍBLIA SAGRADA, Antigo Testamento, 1990. Timóteo 3: 5). O Cristo-Salvador é o centro da teologia de Paulo. A esperança messiânica de uma restauração temporal da realeza davídica, ainda presente nos Atos dos Apóstolos (BÍBLIA SAGRADA, Novo Testamento, 1990. Ato dos Apóstolos 1: 6), torna-se esperança do Reino dos Céus" (Fouilloux, 1998: 235).

A salvação, na Bíblia, é antes de tudo libertação: Deus faz sair do Egito os hebreus cativos (BÍBLIA SAGRADA, Antigo Testamento, 1990. Exôdo 15: 2); depois, protege-os de todo perigo, sobretudo o da invasão estrangeira (BÍBLIA SAGRADA, Antigo Testamento, 1990. 2 Reis 19; BÍBLIA SAGRADA, Antigo Testamento, 1990. IMarcos 3: 18) e Ihes dá a paz. Para merecer isso, o povo deve comportar-se conforme a Lei. Os profetas insistirão, portanto, na relação que existe entre a Salvação e a instauração da justiça (BÍBLIA SAGRADA, AntigoTestamento, 1990. Isaías 59; 60,17-18).

Após o Exílio, será traçada progressivamente a figura de um Messias, portador da salvação de Deus, não somente para Israel, mas para toda a Terra (Is 49,6-8), junto com a espera de uma salvação definitiva no 'Dia do Senhor' (Juízo Final). A oração dos salmos proclama: "A salvação dos justos vem de Deus' 
(BÍBLIA SAGRADA, Antigo Testamento, 1990. Salmo 37), e seu alcance torna-se cada vez mais vasto à medida que se formula a ideia de uma vida após a morte" (idem. Deuteronômio 12: 2-3). Para os cristãos, Jesus é o Salvador que dá Sua vida para reconciliar o homem com Deus e arrancá-lo do pecado e da morte. A salvação, por conseguinte, já foi dada, e ela se realizará plenamente na ressurreição final (BÍBLIA SAGRADA, Novo Testamento, 1990. Romanos 5: 9-10) (Fouilloux, 1998: 234-235).

Tendo Herodes ouvido falar que os Reis Magos avistaram uma estrela no Oriente, que seria um sinal do nascimento de Jesus, foi até eles para saber da veracidade do fato. Alertados em sonho sobre a intenção de Herodes em matar Jesus, os Magos avisaram José e Maria, para que fugissem para o Egito. E assim fez a família de Jesus:

Levante-se, pegue o menino e a mãe dele, e fuja para o Egito! Fique lá até que eu o avise. Porque Herodes vai procurar o menino para matá-lo (BÍBLIA SAGRADA, Novo testamento, Mateus 2: 13-15, p. 1240).

Quando os Magos voltaram para Jerusalém, disseram a Herodes que a estrela não era verdadeira e que, possivelmente, Jesus teria nascido em outra cidade. O rei acreditou nos Magos, mas logo depois descobriu que eles mentiram. Isso causou fúria em Herodes, que mandou matar todos os meninos que nascessem em Belém. O episódio é um verdadeiro genocídio de inocentes. Tudo para evitar que o menino Jesus sobrevivesse, pois Herodes pensava que perderia seu trono se o rei dos judeus tivesse realmente nascido.

Após sete anos no Egito, a família de Jesus foi para a região da Galileia, chamada Nazaré. Todos esses fatos ocorreram "para se cumprir o que foi dito pelos profetas: Ele será chamado Nazareno" (idem, 9-23, p. 1240).

Desde o nascimento, a vida de Jesus foi marcada por andanças, viagens de lugares em lugares, que sinalizavam um caminho de peregrinação, marcado não somente por sua paixão e morte, mas por toda sua vida. (Gr. christos, 'ungido, consagrado por uma unção'; tradução do hb. Mashiah, que deu 'messias').

"No Antigo Testamento(AT), reis e sumos sacerdotes recebiam a unção, que os revestia de uma autoridade provinda de Deus. No Novo Testamento(NT), a 
palavra christos (adjetivo ou nome) designa unicamente Jesus: Cristo, o Cristo, Jesus - o Cristo, isto é, o ungido de Deus, o Messias. É raramente empregado nos Evangelhos. O próprio Jesus recomenda a seus discípulos que não digam a ninguém que ele é o Cristo, temendo que os judeus quisessem fazer dele seu rei e o chefe de uma possível libertação nacional. No entanto, antes de sua paixão, ao sumo sacerdote que the pergunta se ele é o Cristo, o Filho de Deus Bendito, Jesus, responde: "Sou." (BÍBLIA SAGRADA, Novo Testamento, 1990. Marcos 14: 61-62). Mas encontramos frequentemente o nome de 'Cristo' aplicado a Jesus, nos Atos dos Apóstolos, em Paulo e no Apocalipse: é então associada a sua glória de ressuscitado: 'Deus o constituiu Senhor e Cristo, este Jesus a quem vós crucificastes' (BÍBLIA SAGRADA, Novo Testamento, 1990. Atos dos Apóstolos 2: 36)" (Fouilloux, 1998: 69).

Diante do aqui exposto, pretendemos considerar o trajeto da via-crúcis, tendo em vista todo seu percurso, pois a via-crúcis não nos remete apenas ao caminho da condenação à morte na cruz, mas sim, desde o nascimento de Jesus, pois foi em decorrência do pecado original ${ }^{4}$ dos antepassados, que Cristo veio ao mundo e passou por todo o sofrimento, como homem que era, mas que também resistiu e superou até mesmo a morte, por ser o Filho de Deus : "Este é o meu Filho amado, que muito me agrada" (BÍBLIA SAGRADA, Novo Testamento, 1990. Mateus 3: 17, p.1241).

Em nossa pesquisa, observamos que o desenrolar da redenção de Cristo, ou das personagens de Ensaio sobre a cegueira, tem como ponto de partida a cegueira do povo, escuridão ou brancura, ambas como elementos que vedam e impedem a distinção clara das coisas e as possibilidades de recriações, confirmado com a epígrafe: "Se podes olhar, vê, se podes ver, repara", ou no texto bíblico, quando, ao falar com seus discípulos a respeito das atitudes dos fariseus, Jesus os chama de "Cegos!" (BíBLIA SAGRADA, Novo Testamento, 1990. Mateus

\footnotetext{
${ }^{4}$ Esta expressão não figura na Bíblia, mas se desenvolveu na esteira de Santo Agostinho, no séc. $\mathrm{V}$, no cristianismo latino. Foi Paulo quem suscitou a reflexão sobre o que tem sido chamado no Ocidente 'pecado original' e que a linguagem comum reduziu, no melhor dos casos, à desobediência de Adão e Eva e, no pior, ao pecado da carne (Fouilloux, 1998: 200).
} 
23: 19, p.1270), pessoas que não querem ver a essência das coisas e, por isso, vivem na superficialidade. A partir do momento em que as pessoas têm suas "vistas" restauradas, consequentemente, restauram-se também as relações sociais, temporais e espaciais em toda a cidade.

Referimo-nos até agora a uma subversão dos espaços e percursos sagrados. Em Ensaio sobre a cegueira, os fatos bíblicos acontecem em espaços profanos (como o supermercado), carnavalizados (como a igreja). Algumas personagens, como a mulher do médico e a prostituta, têm atitudes diferenciadas que as aproximam de figuras como a Virgem Maria e Maria Madalena. Em virtude desse movimento de elevação e rebaixamento, que podemos ver ao longo da narrativa, entre outros fatores, optamos por recorrer a Bakhtin como principal base teórica para o desenvolvimento de nossas argumentações. Tendo em vista a peregrinação das personagens, queremos abordar ainda o "tempo de transformação" (BAKHTIN, 1998), que também acreditamos fazer parte da estrutura narrativa do romance.

Ao lado de conceitos como o de paródia e de carnavalização, de sua autoria, escolhemos também o conceito de cronotopo, como fundamento analítico deste trabalho, pois abrange os três elementos que nos interessam: espaço, tempo e personagem, unidos pela articulação da visão de mundo que sustenta esta tríade.

Para explicar o termo cronotopo, Bakhtin afirma ter se baseado na teoria da relatividade, proposta pelo físico Albert Einstein, devido à concepção de que o espaço possui um caráter físico e de que o tempo ocorre no seu meio. Transposto para a arte literária, este mesmo processo ocorre quando o espaço é penetrado pelo tempo, gerando, consequentemente, a fusão dos dois elementos.

Segundo Bakhtin, o cronotopo é de natureza bifocal. Pode ser encarado como um elemento estrutural de uma determinada obra (o lugar onde se atam e se desatam os nós da intriga), ajudando a compreender esse texto específico na sua singularidade. Mas também pode ser visto na sua "trans-historicidade", como um elemento da estrutura de certos tipos de textos. Nesta concepção, Bakhtin examina inicialmente os cronotopos de três tipos de romance: o de aventuras e 
provas, o de aventuras da vida cotidiana e o do romance biográfico, defendendo que, a partir das mudanças ocorridas nas configurações desses cronotopos, seria possível ver o desenvolvimento do romance de aventuras praticado na Europa até o século XVIII (Cunha apud Ceia, 2005).

Quanto ao tempo, o acaso é um elemento constante no romance de cavalaria, na medida em que as aventuras surgem sempre nos "hiatos" das séries temporais normais, nos espaços em que as normas são subitamente abolidas e em que o acontecimento prodigioso se torna quase normal. Diz Bakhtin:

Nos romances de cavalaria, o mundo inteiro se torna prodigioso; o prodígio se torna habitual (sem deixar de ser prodigioso) e o eterno imprevisto deixa de ser imprevisto. [...] O mundo, para o herói, só existe sob o signo da magia, e este é, para ele, o mundo da normalidade. (BAKHTIN, 2002, p.301).

Bakhtin também aproxima o romance de cavalaria da epopeia, e isso determina a especificidade cronotópica desse tipo de romance: "o mundo das maravilhas no tempo da aventura" (BAKHTIN, 2002, p. 300). No romance de cavalaria, segundo o autor, "assiste-se a uma hipertrofia fabulosa do tempo: as horas se alongam, os dias se encurtam e viram instantes, e o próprio tempo pode ficar enfeitiçado" (idem, p. 301). Analogamente, ocorre uma mudança semelhante no espaço, que ganha uma distorção subjetiva, emocional e de conotação simbólica.

Para o desenvolvimento deste estudo, interessa-nos também o que Bakhtin destaca nessas obras: uma aguda percepção das contradições do tempo em que foram escritos, que exigiram a apresentação minuciosa da sua histórica diversidade contraditória. Para dar conta desse aspecto, os autores - e Dante, para o caso que nos importa aqui - representam verticalmente essa diversidade.

Dante esboça a diversidade histórica do seu tempo, desenhando os nove círculos do Inferno, situados abaixo da Terra, os sete círculos do Purgatório e, mais alto, os dez céus (BAKHTIN, 2002, p. 303). Nas palavras de Bakhtin, "embaixo, as matérias grosseiras dos seres e das coisas; no alto, nada além da luz e da voz" (idem, p. 303). 
Em relação a essa lógica temporal, Bakhtin destaca a eliminação no contexto de A Divina Comédia, da "compartimentação temporal". No lugar dela, o que vemos é a simultaneidade e a coexistência de todas as coisas (na eternidade).

Mas Bakhtin também ressalta que as personagens de A Divina Comédia, sendo profundamente históricas, querem escapar da intemporalidade desse mundo vertical e têm, por isso, um impulso "no sentido da horizontalidade histórica produtiva", desejando participar ativamente do acontecimento histórico (p. 304).

Alongamo-nos nesta exposição acerca do cronotopo dos romances de cavalaria e do romance "enciclopédico" de Dante, pois acreditamos que em Ensaio sobre a cegueira as relações parecem ser, até certo ponto, o avesso disso, porque nos romances da Idade Média havia a busca material, de algo concreto, o que não ocorre no romance de Saramago. No entanto, é pelo avesso que se opera o diálogo com essas obras.

Fazendo uma síntese sobre a importância de enfocarmos os cronotopos nesta análise, podemos considerar que os elementos fundamentais dos cronotopos são importantes em Bakhtin, não somente porque possibilitam uma nova visão a respeito das relações entre espaço, tempo e personagem, mas, sobretudo, porque a proposta de análises conceituais do autor está totalmente interligada à realidade cotidiana e histórica de uma sociedade. O cronotopo envolve a realidade, é uma ponte entre o mundo real e o mundo representado, é um entrelaçamento do homem com a fusão do tempo e do espaço.

Os espaços serão estudados ainda sob a perspectiva da teoria de Marc Augé (1994), da qual extrairemos os conceitos de "lugar antropológico" e de "nãolugar", ambos relacionados à "supermodernidade". Para o autor, os lugares antropológicos são os que mantêm elos relacionais, identitários e históricos, e "não-lugares" são aqueles espaços que não mantêm nenhum laço, tornando-se lugares de passagem, repletos de "hiatos". Para o autor, a supermodernidade é caracterizada como um "estado que impõe, às consciências individuais, novíssimas experiências e vivências de solidão diretamente ligadas ao surgimento e à proliferação de "não-lugares" (AUGÉ, 1994, p. 86). 
A nosso ver, em Ensaio sobre a cegueira, os espaços do manicômio, da rua, da casa da rapariga, do supermercado e da igreja constituem "não-lugares", pois neste contexto, são lugares desvitalizados, embora neles ocorram ações importantes que marcam, cada uma ao seu modo, a deterioração das relações espaços-temporais e sociais. A relação entre a tríade espaço, tempo e personagem, proposta por Augé, possui algumas características que contribuem para a análise do romance, assim como o conceito de cronotopo apresentado por Bakhtin. Por isso, pensamos ser importante a utilização de ambas as teorias no desenvolvimento deste estudo.

Além disso, por estarmos tratando desta obra de Saramago sob uma perspectiva que envolve o sagrado, precisamos recorrer também a estudos sobre o mito e sua relação com os gestos ritualísticos que, neste caso, parecem ligar-se às cosmogonias.

Esclarecendo melhor, o banho da mulher das insônias e das cinco mulheres, realizados pela mulher do médico, assim como o banho que dá em si mesma, sugerem um ritual de iniciação, de purificação, para o ingresso em uma nova vida. Mais adiante, o episódio em que as três mulheres se banham sob a água da chuva pode ser lido também como um ritual de purificação. Elas podem muito bem significar as Três Graças da Mitologia, como sugere o próprio narrador.

De modo semelhante, o episódio anterior, em que o manicômio é destruído pelo fogo, pode ser lido como um ritual de destruição (tal como ocorreu com Sodoma e Gomorra), ou como a lenda da Fênix, em seu ritual de passagem da vida velha para a nova (BACHELARD, 1997). Assim sendo, enquanto episódios ritualísticos demandam também uma volta para as interpretações dos símbolos que os envolvem, incluindo o simbolismo do número sete e dos elementos essenciais do mundo material, como o fogo e a água, por exemplo.

Em relação ao texto bíblico, delimitaremos as passagens da via-crúcis (tendo em vista que não se trata de um curto percurso, mas de toda a vida de Jesus) através dos seguintes temas: encontro, sofrimento e queda. Esses três motivos fundamentam a via-crúcis, sendo que a ressurreição trata da vitória sobre a morte. 
A paixão de Cristo, ou seja, sua via-crúcis, é dividida em quatorze partes ou passos, que marcam momentos do caminho doloroso que percorreu em sua peregrinação, até sua ressurreição, que completa sua missão terrena. No Dicionário Cultural da Bíblia (1998) de Danielle Fouilloux, encontramos a definição da paixão como o "caminho da cruz", que "os fiéis revivem (...), sobretudo na sexta-feira santa, dia em que se comemora a morte de Jesus" (FOUILLOUX, 1998, p. 54).

Dessa forma, consideraremos o seguinte no decorrer dos capítulos: o último encontro com os discípulos, por preceder sua condenação, a primeira e a segunda estações, que tratam sequencialmente da condenação e do recebimento da cruz, enquanto pena de sua condenação. No segundo capítulo, consideraremos da décima à décima quarta estações, que relatam momentos de intenso sofrimento da caminhada de Jesus. Para o terceiro capítulo, consideraremos as quedas na peregrinação, representadas através da terceira, sétima e nona estações, e no quarto e último capítulo, abordaremos a ressurreição de Jesus, como um momento de renovação e transformação em sua caminhada terrena, conforme a narração do texto bíblico, especificamente os evangelhos.

Cada etapa da via-crúcis de Jesus será relacionada à peregrinação das personagens de Ensaio sobre a cegueira, estabelecendo um paralelo com o caminho de sofrimento, dor e morte que elas vivenciaram no desenrolar da trama.

Utilizando este material teórico como nossa base, pretendemos, então, dedicar cada um dos capítulos seguintes ao exame dos espaços individuais que compõem a já referida via-crúcis do grupo dos sete peregrinos, que constituem os protagonistas desta obra.

Assim, no primeiro capítulo teremos os espaços da rua (o cruzamento), do consultório (os primeiros casos de cegueira), da casa do médico (seu nervosismo e sua cegueira logo de manhã). Todos eles compõem o espaço da aventura inicial: o desencadeamento da epidemia de cegueira branca, que parece uma alegoria da deterioração do espaço social; o episódio, inicialmente concebido como um fenômeno prodigioso, sobrenatural, começa a ser visto como parte de 
uma "nova normalidade", mas, ao mesmo tempo, traz em seu interior os traços da sociedade "doente" da época contemporânea.

A leitura que podemos fazer desses ambientes (típicos "não-lugares") remete ao modo como Bakhtin se refere aos elementos espaço-temporais da obra de Dante: só admitem uma interpretação alegórica ou simbólica e, ao mesmo tempo, retratam "a diversidade contraditória" da crise vivida pela sociedade contemporânea.

Como acontecimentos importantes desta etapa, destacamos: o primeiro caso de cegueira no cruzamento de trânsito e a ajuda solidária transformando-se em falta de solidariedade (o roubo do carro) e o episódio da cegueira da rapariga, revelando um momento dessa falta de solidariedade; em suma, os primeiros casos de cegueira ao lado do primeiro encontro dos seis cegos, que formam os principais acontecimentos dessa etapa.

O primeiro capítulo é marcado pelo encontro dos seis cegos no consultório do médico e, a partir daí, propomos um paralelo com a via-crúcis de Cristo, que também é marcada por um encontro, o último que teria com seus discípulos durante a festa da Páscoa, antes de seu julgamento e condenação.

Em relação ao encontro, que ocorre tanto em Ensaio sobre a cegueira como nos evangelhos, observa-se uma mudança completa na narrativa, com alguns elementos que se assemelham, como o lugar escolhido e a ambientação do encontro: uma cidade em ambos os textos.

$\mathrm{Na}$ narrativa bíblica, a peregrinação de Cristo se dá na cidade de Jerusalém, que é o cenário de seu percurso, a qual, no século I, estava dividida entre a Judeia e a Samaria. Os interesses políticos e sociais perpassavam a questão religiosa e, por isso, a existência, na época, de grupos denominados político-religiosos, como os fariseus, saduceus, escribas, anciãos e outros, que viam na pessoa de Jesus um risco aos seus interesses pessoais. ${ }^{5}$

O percurso de Cristo é marcado, então, pelo último encontro com seus discípulos, assim como em Ensaio sobre a cegueira acontece um encontro, que

\footnotetext{
${ }^{5}$ A respei to dos grupos que existiam na Palestina, na época de Jesus, foi consultada a Introdução ao Novo Testamento da Bíblia - Edição Pastoral das Edições Paulinas, 1990, que traz o subtítulo Palestina no tempo de Jesus, p.1234.
} 
seria o primeiro dos seis cegos no consultório médico. Ocorre numa cidade que não tem nome, mas com a indicação de que seria uma cidade moderna, contemporânea (semáforo, correria, muitas pessoas, pressa etc).

O primeiro encontro dos cegos não foi marcado antecipadamente; ocorreu por acaso. Todas as personagens nele presentes revelam um problema de vista, cada um à sua maneira (o primeiro cego, sua esposa, o médico, a rapariga dos óculos escuros, o velho da venda preta e o garoto estrábico). Assim como a cidade, as personagens não têm nome, sendo apenas mencionadas suas características.

O segundo capítulo abordará o espaço do manicômio que, a nosso ver, dialoga com o Inferno de Dante. Constituindo o microcosmo da sociedade doente, retrata a segunda etapa da deterioração: um caso de epidemia, que tenta ser contida por meio da internação dos acometidos pela doença. No momento seguinte, a situação assume proporções maiores e incontroláveis, deixando de ter o caráter epidêmico; passa, então, a assumir um caráter mais definitivo, de condição permanente dos indivíduos daquela sociedade. Existe, nesta etapa, uma tentativa de organização do caos, sob a liderança da mulher do médico.

Com a evolução da doença, vão gradativamente surgindo outros líderes (antagonistas, inclusive), como ocorre na constituição de qualquer sociedade. Novos líderes de grupos diferenciados: o dos cegos ladrões e, opondo-se a eles, o grupo das mulheres. A partir da formação desses novos grupos, surgem os conflitos e as tentativas de soluções de parte a parte: os estupros, o assassinato e o incêndio. O clímax dessa situação se dá com o estupro e o consequente assassinato do cego ladrão, pela mulher do médico e, finalmente, pelo incêndio que destrói tudo.

Outro fato importante decorre da atitude de uma mulher que havia chegado há pouco tempo no manicômio. Ela, num ato de indignação, decide incendiar a camarata dos cegos ladrões.

$O$ fato de essa personagem ser consumida pelas chamas pode nos levar a pensar em um ritual sacrificial, tal qual Cristo na cruz, como o próprio "cordeiro imolado", mas no caso da mulher, como o corpo sacrificial, espécie de co- 
redentora dos cegos. Tais fatos mudam completamente o percurso da vida das personagens.

Enfocaremos, ainda, o episódio do manicômio em chamas, como anúncio de uma iminente libertação da quarentena. $O$ fogo aparece como elemento fundamental de libertação, como um ritual de destruição e renovação ao mesmo tempo. Nesse capítulo, trataremos do segundo percurso das personagens, estabelecendo um paralelo com a caminhada de Cristo em sua via-crúcis. Esse percurso é marcado pelo intenso sofrimento das personagens de Ensaio sobre a cegueira, bem como o de Cristo, como relata o texto bíblico.

Nos dois textos percebe-se o sofrimento atingir o ponto de transformar a feição das personagens, um momento angustiante e de dor lancinante, que prossegue conforme a caminhada continua.

No texto bíblico, destacaremos os momentos de dor que antecedem e prosseguem até a morte de Cristo na cruz, quando ele é pregado, zombado, maltratado ainda com vida, até sua descida da cruz, já morto.

No terceiro capítulo abordaremos o espaço da cidade, como as ruas, a casa da rapariga, o supermercado, a igreja (semelhante à passagem pelo Purgatório na Divina Comédia, de Dante). Esta é a terceira etapa, em que restam apenas os sete integrantes no centro da trama.

Embora apareçam outras personagens, elas não são focadas como o grupo das sete pessoas que parecem corresponder, simbolicamente, a seres iniciados (ELIADE, 1989), predestinados a reconstruir a sociedade sobre novas bases, humanizada e purificada.

Acontecimentos importantes dessa etapa são a caminhada pelas ruas, como um desfile carnavalesco, a ida ao supermercado e à casa da rapariga, a entrada na igreja e a visão das estátuas cegas. A imagem criada durante esse percurso da peregrinação parece-nos indicar um imenso desfile do mundo e das coisas às avessas (BAKHTIN, 1987).

Nesse capítulo, faremos um paralelo com as quedas da via-crúcis de Cristo, em sua caminhada rumo ao calvário, com as quedas das personagens de Ensaio sobre a cegueira. Consideramos importante a análise das quedas porque marcam 
momentos relevantes da via-crúcis das personagens imersas em um espaço degradado em sua essência, em específico a cidade, tal como ocorre, a trama parece ser um homônimo da pintura de Brueghel (1568). Há também a parábola dos cegos do texto bíblico: "São cegos guiando cegos. Ora, se um cego guia outro cego, os dois cairão num buraco." (BÍBLIA SAGRADA, Novo Testamento, 1990. Mateus 15: 14, p. 1259), a qual retrata um grupo de cegos, que perambulam por uma cidade e que acabam caindo em fila uns sobre os outros, num movimento lento e contínuo. Dessa forma, acreditamos que as quedas no texto bíblico, que vivencia Jesus em seu trajeto, apresentam alguns elos com Ensaio sobre a cegueira. Metaforicamente, as quedas sinalizam o percurso da morte nos dois textos, bem como na pintura.

Um outro capítulo tratará do retorno à casa. Abrangerá o ritual da entrada no Templo sagrado, o ritual da purificação, o papel das mulheres nesse ritual e o papel do casal "primordial", representado pelo velho da venda preta e pela garota de programa (espécie de Maria Madalena). Trata-se da quarta e última etapa da via-crúcis do grupo, representando uma possibilidade de reconstrução social. Nessa etapa, a simbologia da água é reveladora do processo ritualístico que as personagens vivenciam através dos banhos (água) e dos ritos de purificação: o grupo pôde, então, vislumbrar uma nova visão de mundo. A relação feita com o texto bíblico e a volta da visão como ressurreição das personagens. Nesse trajeto, em que as personagens recuperam a visão, estabeleceremos pontos de contato com a narrativa bíblica que narra a ressurreição e a saída de Cristo do sepulcro. O que nos parece é que através do sofrimento, da dor e das quedas, as personagens de Ensaio sobre a cegueira são, então, gratificadas pela nova vida que terão a partir desse novo momento. Tal como ocorre também no texto bíblico.

Considerando que a ênfase é na via-crúcis, portanto no sofrimento das personagens partimos do espaço a fim de estabelecer um paralelo entre a degradação humana com a degradação espaço-temporal presentes na narrativa, à medida que as personagens recuperam a visão os elementos espaço-temporais dão sinais de possível reestruturação, ou seja, estão interligados em sua essência 
tanto na desconstrução como na possível reconstrução como indica o final da narrativa.

Com o objetivo de responder às nossas indagações acerca da desconstrução e reconstrução espaço-temporal nesta obra de Saramago, esperamos ter escolhido os percursos corretos e que as setas indicadoras nos ajudem a não perder de vista o caminho que, a partir de agora, traçaremos. 


\section{Os primeiros passos da via-crúcis - o primeiro encontro}

No primeiro estágio da via-crúcis as personagens sofrem por sentirem desorientadas no espaço em que estão inseridas, tal sofrimento ocorre pelo fato de serem acometidas por um mal branco na visão, impossibilitando-as de prosseguir com o curso normal da vida, em decorrência disso o espaço e o tempo adquirem um significado especial na medida em que aumenta o número de pessoas atingidas, dá-se início a instabilidade espaço-temporal.

Neste capítulo, trataremos da deterioração do espaço social em Ensaio sobre a cegueira, a partir dos primeiros casos de cegueira e, em paralelo, relacionaremos a experiência das personagens pelos diversos espaços com a narrativa de Cristo durante sua vida, conforme o relato bíblico.

Em Ensaio sobre a cegueira, o primeiro caso de cegueira ocorre no espaço do cruzamento de uma rua, onde, repentinamente, um homem que conduzia um veículo não pode dar partida por sentir opacidade na vista, uma espécie de brancura leitosa.

Angustiado, o homem fica com os olhos brilhantes, pálpebras arregaladas, compactas como porcelana e apesar de não apresentar qualquer aspecto doentio, diz estar cego. No desenrolar das ações, o sinal verde se acende e o carro permanece imóvel, contrapondo-se à agitação cotidiana da cidade (buzinas, gritos e impaciência, por parte dos outros automobilistas). Observamos na citação abaixo o desenrolar da ação do primeiro cego e o início de sua via-crúcis:

\footnotetext{
Estou cego, estou cego, repetia com desespero enquanto o ajudavam a sair do carro, e as lágrimas, rompendo, tornaram mais brilhantes os olhos que ele dizia estarem mortos (SARAMAGO, 1995, p.12).
}

Além da cegueira da personagem, o fragmento indica que o espaço em que ocorre a primeira ação é uma rua, onde ocorre o primeiro caso de cegueira. $O$ motorista vê-se impossibilitado de prosseguir no fluxo do trânsito e a aparente organização da rua fica comprometida, indicando que a ordem é apenas aparente 
e está prestes a se desestruturar. Esse contexto sinaliza os primeiros momentos de desorganização do espaço, que podem ser vistos através do tumulto causado pelo carro estagnado e a gritaria dos outros motoristas. De acordo com os estudos de Bakhtin (2002): "A estrada é particularmente proveitosa para a representação de um acontecimento regido pelo acaso (mas nem só para isso). A partir daqui, compreende-se o papel temático da estrada na história do romance" (BAKHTIN, 2002, p. 350).

Podemos constatar que a tensão e a pressa, somadas às características apresentadas pela realidade (cores, luzes, formas sugeridas etc), trazem, subliminarmente, a ideia de que a ordem é apenas aparente e está prestes a se desestruturar. Essa tensão também fica patente pela impaciência e nervosismo dos automobilistas, que querem prosseguir com seus carros a todo custo:

Os automobilistas, impacientes, (...) mantinham com tensão os carros, avançando, recuando, como cavalos nervosos (...) O sinal verde acendeuse enfim, bruscamente os carros arrancaram (...) o primeiro da fila do meio está parado (...) os carros atrás dele buzinam frenéticos (...) (SARAMAGO, 1995, p.11, 12).

Dá-se início a um primeiro momento de desorganização e tensão, que parte das pessoas apressadas e impacientes que esperavam o sinal para prosseguir seu caminho e não conseguem. A partir desse acontecimento, toda a ordem da cidade parece entrar em um processo de ruptura. O primeiro movimento do semáforo, que indicava organização, contrapõe-se a esse segundo momento, indicando o início da deterioração espaço-social causada pelo caso de cegueira branca.

$\mathrm{Na}$ sequência das ações, ao passar acidentalmente ao lado do carro do cego, um pedestre se dispõe a levá-lo para casa e deixá-lo à porta de seu apartamento. Ele entra, enquanto aguarda sua esposa, que ainda não havia chegado do trabalho, se fere bate violentamente num vaso por não o ver, provocando, em sua mão, um ferimento que sangra. A desorientação da personagem devido a cegueira é um indício que alerta sua esposa que, logo ao chegar, constata o estado do marido e se dispõe a levá-lo ao médico: "Vamos, 
temos o táxi à espera...". Mantiveram-se calados até o consultório do médico (SARAMAGO, 1995, p. 20).

A partir do primeiro caso, a cegueira passa a contagiar outras personagens que mantêm contato com a primeira vítima, como, por exemplo, na sequência em que o rapaz ajuda o homem cego a ir para casa, mas rouba seu carro e, já na posse deste, sente algo diferente:

Não será possível, portanto neste caso, deslindar que parte dos medos e que parte da consciência afligida começaram a apoquentar o ladrão assim que pôs o carro em marcha. Sem dúvida nunca poderia ser tranquilizador ir sentado no lugar de alguém que segurava com as mãos este mesmo volante no momento em que cegou, que olhou através deste parabrisas e de repente ficou sem ver (...) (SARAMAGO, 1995, p. 26).

Após deixar o cego em casa e fugir com o carro, o narrador nos mostra o interior do ladrão com uma consciência moral querendo aflorar, talvez um remorso e, em contrapartida, uma exigência da razão no sentido de não se deixar envolver por emoções que Ihe desviassem a atenção: "O ladrão redobrou de atenção ao trânsito para impedir que pensamentos tão assustadores lhe ocupassem por inteiro o espírito" (SARAMAGO, 1995, p.27). O ladrão reluta, conforme a narrativa, contra seus sentimentos, possivelmente para resguardar-se da própria consciência. Percebemos, então, com a ajuda da voz narrativa, o conflito interior dessa personagem, conforme lemos nos fragmentos acima.

Ao longo da narrativa, comportamentos como o dele (individualismo, interesse ao bem próprio, ajuda interessada a algum benefício) continuam a surgir, o que nos coloca diante da possibilidade que a solidariedade "conveniente" é um traço comum a algumas pessoas.

Analisando as ações do ladrão de carros, observamos que, no impulso de ajudar o primeiro cego não estava, ao menos explicitamente, o desejo de roubar o automóvel. Tal atitude nos leva a refletir sobre sua situação de ex-presidiário, de uma pessoa desprovida de certos requisitos para uma vida digna, que é revelado pelo medo de que foi possuído ao dirigir o carro roubado: "Neste caso, deslindar 
que parte dos medos e que parte da consciência afligida começaram a apoquentar o ladrão"(SARAMAGO, 1995, p.26)

O medo que ele sentia ao volante nos faz refletir também acerca da personagem no limiar estudado por Bakhtin (1981), que é aquela em constante tensão, no limite da vida e da morte, da bondade e da maldade, ou seja, vivencias repletas de inconstâncias que a conduz a um novo estágio de existência, mais consciente de si e do mundo que o rodeia, tal como podemos observar no fragmento seguinte:

De súbito, sem que ele contasse, a consciência acordou e censurou-o asperamente por ter sido capaz de roubar o automóvel a um pobre cego (...) Assombrava-o o espírito lógico que estava descobrindo na sua pessoa, a rapidez e o acerto dos raciocínios, via-se a si mesmo diferente, outro homem ${ }^{6}$, e se não fosse este azar da perna estaria disposto a jurar que nunca em toda a sua vida se sentira tão bem (SARAMAGO, 1995, p.78, 79, 80).

O remorso fez com que o ladrão se sentisse uma outra pessoa. Fez com que ele criasse uma outra imagem de si mesmo ("outro homem"), ou seja, a partir do momento que sua consciência desperta para reconhecer a outra pessoa, conseguiu ver a si próprio como diferente, com novos pensamentos. Sentimentos de mudança o fizeram procurar meios de aliviar a dor. Partindo em direção ao portão, arriscou-se e foi morto: "(...) a cara e o crânio rebentados pela descarga" (SARAMAGO, 1995, p. 83). Assim foi o destino do ladrão que utilizou a conveniência em ajudar, para roubar o primeiro cego, conscientizou-se da atitude errada, sentiu remorsos e se viu como um novo homem, e morreu ao tentar algo para aliviar a dor que sentia na perna.

O segundo a cegar, como vimos, foi o ladrão de carro, depois, o oftalmologista seguido dos demais: a rapariga nova dos óculos escuros, o garoto estrábico, a mulher do primeiro cego, o velho da venda preta e, por fim, todos os cidadãos, exceto a mulher do médico.

Todas as personagens que cegaram sofreram, mas, para ilustrar outro momento de ruptura das relações humanas, a partir do primeiro encontro,

\footnotetext{
${ }^{6}$ Grifo nosso.
} 
trazemos para análise o fato ocorrido com a rapariga dos óculos escuros. No momento de sua cegueira ela fazia um programa com um homem. $O$ afeto que sentia por ele não a livrou do vexame que passaria ao descobrir que estava cega: “(...) mal ousava chorar e lamentar-se quando, com maus modos, vestida a trouxemouxe, quase aos empurrões, a levaram para fora do hotel." (SARAMAGO, 1995, p. 36).

No espaço do hotel, percebe-se o esfacelamento das relações humanas. A moça foi escorraçada daquele espaço que the servia de trabalho e prazer; tornouse, aquele, um lugar do ridículo, do escândalo.

O espaço do hotel pode ser tratado, utilizando os estudos de Augé (1994), como um "não-lugar", aquele lugar que é unicamente de passagem. Contudo, observamos que, mesmo sendo de passagem, nele tem lugar cenas, ações (o encontro amoroso da rapariga dos óculos escuros com um homem em seguida a cegueira que a ataca repentinamente) que denotam um rompimento das relações sociais. No hotel, ocorre a constituição de um novo "cronotopo", em que o espaço se funde no tempo, ou seja, o espaço intensifica-se a tal ponto e penetra 0 movimento do tempo, impossibilitando o homem visualizar os elementos tempo e espaço separadamente, o tempo torna-se visível como o espaço e de acordo com Bakhtin(2002): "Parece que o tempo se derrama no espaço e flui por ele (...)"(p.350) e irrompe a metamorfose da personagem. Dessa forma, Saramago subverte o hotel, tido como um "não-lugar" (AUGÉ, 1994), ou lugar de passagem, em um espaço de fundamental importância para a mudança de vida da personagem.

Os lugares de passagem são aqueles que, segundo Augé, não imprimem elos relacionais ou experiências. São espaços vazios de ações. No entanto, eles são subvertidos e neles ocorrem ações basilares na formação da narrativa, como por exemplo, no cruzamento, onde ocorre o primeiro caso de cegueira, ou no hotel. São lugares onde as relações humanas são apresentadas em processo de deterioração, sobretudo, pela evidente falta de solidariedade entre as personagens na cena do hotel, em que os laços que as ligavam umas às outras são totalmente rompidos. Ao invés de ajudá-la a recompor-se e recuperar a dignidade, as 
personagens quiseram ver-se livres da doença, do "mal branco", sendo esse o fator mais importante, naquele momento, para aquelas personagens ("quase aos empurrões, levaram-na para fora do hotel").

Analisando o caso da cegueira do primeiro cego, do motorista e o da rapariga de óculos escuros, observamos que retratam o início do caos instaurado no romance. Mas, em outro momento, percebemos que nem todas as relações de solidariedade humana foram rompidas. Na personagem da mulher do médico o elo solidário e humano ainda persiste, como se ela tivesse plena percepção do mundo ao seu redor:

\begin{abstract}
Ah, já estás levantando, disse ela, e ele respondeu, Estou (...). Bons dias, meu amor (...). Acho que não irão ser muitos bons, Não vejo, e acrescentou, Suponho que fui contagiado pelo doente de ontem (...) o rosto transformou-se-Ihe. Empurrou a mulher quase com violência, ele próprio recuou, Afasta-te, não te chegues a mim, posso contagiar-te, e logo a seguir, batendo na cabeça com os punhos fechados, Estúpido, estúpido, médico idiota, como é que não pensei, uma noite inteira juntos, devia ter ficado no escritório, com a porta fechada (...) Por favor, não fales dessa maneira (...) anda, vem, vou-te preparar o pequeno-almoço, Deixa-me, deixa-me, Não deixo, gritou a mulher, que queres fazer, andar aí aos tombos, a chocar contra os móveis (...) enquanto eu assisto tranquilamente ao espetáculo, metida numa redoma de cristal à prova de contaminações. Agarrou-o pelo braço com firmeza e disse, Vamos, meu querido (...) (SARAMAGO, 1995, p. 38).
\end{abstract}

No extenso fragmento que constitui um recorte do diálogo entre o médico e a sua mulher, observamos que a cegueira do médico fê-lo encher-se de desespero e tristeza, pois não queria acreditar no que estava ocorrendo. A falta da visão parecia-Ihe a falta da própria existência, mas a presença de sua mulher foi um fato importante, pois, com o seu nervosismo, pensou que poderia resguardá-la do contágio, contudo, a consciência da mulher, sua coragem e seu amor fizeramno entender a incondicional humanidade que ela havia demonstrado com aqueles gestos solidários e fraternos. O extremo de sua humanidade se deu quando ela se fez de cega com um único intuito: o de não deixar o marido sozinho. Em nenhum momento, ela se preocupou se iria ou não ficar cega. Seu objetivo foi unicamente o de servir ao outro, no caso, o marido. 
Após os primeiros casos de cegueira, as personagens reúnem-se em um consultório oftalmológico. Elas não prevêem o caminho que percorreriam a partir desse momento e somente no desenrolar da narrativa fica evidente o motivo desse primeiro encontro, que parece ser por acaso:

A mulher informou a empregada da recepção de que era a pessoa que há meia hora tinha telefonado por causa do marido, e ela fê-los passar a uma pequena sala onde outros doentes esperavam. Havia um velho com uma venda preta num dos olhos, um rapazinho que parecia estrábico (...) uma rapariga nova de óculos escuros (...) (SARAMAGO, 1995, p. 21).

No fragmento escolhido para ilustrar o primeiro encontro, estão presentes as personagens que comporão o grupo guiado pela mulher do médico.

No consultório estava o médico, que atendeu o primeiro cego e sua esposa; o velho da venda preta que aguardava o atendimento, juntamente com a rapariga dos óculos escuros, e o rapazinho estrábico. Esse foi o primeiro encontro do grupo e nele não estava a mulher do médico, a única que não foi contagiada pela cegueira branca.

Esse encontro revela uma característica do romance de aventura de que trata Bakhtin em Questões de literatura e de estética: a teoria do romance (2002), no capítulo intitulado "Formas de Tempo e de Cronotopo literário no Romance Ensaios da poética histórica". Referindo-se à importância do encontro, o autor diz:

O encontro é um dos mais antigos acontecimentos formadores do enredo do epos (...) Deve-se, sobretudo notar a estreita ligação do motivo do encontro com motivos como a separação, a fuga, o encontro, a perda (...). Tem significado particularmente importante a estreita ligação do motivo do encontro com o cronotopo da estrada (...), vários tipos de encontro pelo caminho (...) (BAKHTIN, 2002, p. 223).

Ao apresentar o estudo a respeito das características dos romances de aventura, Bakhtin (2002) propõe o exame dos cronotopos do encontro e da estrada, como típicos da estrutura desses romances.

Em Ensaio sobre a cegueira, podemos entender a vida das personagens como a estrada, no sentido metafórico. Neste caso o consultório é uma espécie de ponto da estrada da vida que está sendo percorrida. O consultório ganha um 
significado especial com o encontro das personagens que após a cegueira fazem juntas a experiência da peregrinação pelos mais variados espaços na narrativa. $O$ tempo é marcado pela espera e busca da cura dos problemas de visão que de forma evolutiva(conjuntivite da garota de programas, estrabismo do garoto, catarata do velho) chega a cegueira branca e toma um impulso novo.

Nesse sentido, tanto os primeiros casos de cegueira quanto o encontro no consultório marcam o início da via-crúcis das personagens e impulsionam a narrativa. Trata-se de um ponto, ao qual se deve retornar, pois da mesma forma que elas ali se encontraram, estarão unidas pelo fio da cegueira, e não só unidas como também predestinadas a passarem pelas situações adversas e cruéis, já que nesse momento, todas se encontravam ali por um único motivo: um problema na visão.

Consideramos até aqui a cegueira branca e os primeiros casos de cegueira, como o motivo do caminho de sofrimento e dor que, a partir de então, as personagens percorreriam. Os espaços apresentados até agora revelam que a organização da cidade começa a fragilizar-se e, ao que tudo indica, uma certa desorganização foi iniciada.

Procurando estabelecer um paralelo entre o texto bíblico, que narra a vida de Cristo e seu caminho de sofrimento, resgatamo-lo para, em seguida, analisar os pontos de contato com o caminho das personagens de Ensaio sobre a cegueira.

A via-crúcis de Cristo se inicia desde a concepção, através da peregrinação de Maria e José, após a anunciação do anjo Gabriel sobre ser ela a virgem escolhida para mãe do Salvador da humanidade:

Maria estava prometida em casamento a José, e, antes de viverem juntos, ela ficou grávida pela ação do Espírito Santo. José, seu marido, era justo. Não queria denunciar Maria, e pensava em deixá-la, sem ninguém saber. (...) Ela dará à luz um filho, e você Ihe dará o nome de Jesus, pois ele vai salvar o seu povo dos seus pecados (Bíblia Sagrada, Novo Testamento, 1990. Mateus $1: 18,19,21$ p. 1239). 
De acordo com o Novo Testamento, Cristo teve um papel importante na história da salvação da humanidade, já que Ele veio para redimir o povo do pecado original, desde os primeiros homens criados por Deus: Adão e Eva.

Conforme o livro do Gênesis, Deus criou o céu e a terra e as águas, que a princípio parecia o caos e, por isso, Ele deu forma à terra e ao firmamento, preenchendo-os de estrelas, luz. Fez surgir seres vivos, feras, animais domésticos e frutos, enfim tudo de que precisava um Paraíso. Depois, criou o homem à sua imagem e semelhança depois de sete dias, Deus então descansou, considerando que tudo o que criara era bom e perfeito.

Depois de criar o homem, Deus criou também a mulher para viverem juntos e felizes, desfrutando de tudo o que havia no Paraíso, chamado Éden. Todavia, pediu-Ihes que não comessem de uma única fruta: a do conhecimento. Eva, a mulher, contrariando as ordens de Deus e levada pelas manobras de uma serpente, foi convencida a comer do fruto proibido a dá-lo ao seu companheiro, Adão. (BÍBLIA SAGRADA, Antigo testamento, Gênesis 3: 1-24, p. 16). A partir desse fato, o casal sentiu vergonha de sua nudez, escondendo-se de Deus, que logo percebeu que haviam desobedecido às Suas ordens. Deus, então, retirouIhes todas as regalias e prometeu-lhes uma vida dura, difícil e de sofrimento, porque se tornaram pecadores, e o pecado deles seria estendido a todas as criaturas que existissem, a partir desse fato.

O pecado cometido por Adão e Eva deixou uma mácula nas gerações que se seguiram, ou seja, todo homem e mulher já traziam a marca do pecado original. Todos condenados ao sofrimento, à dor e à morte, enfrentando violência, fome, peste, seca, inundações, enfim, as mais diversas dificuldades para a sobrevivência na Terra. "De fato, a Bíblia conhece um estado desordenado do mundo que acarreta assassínios, guerras, invejas, orgulho e que remonta à origem dos tempos. Sob uma forma narrativa, ela apresenta de maneira cronológica uma experiência profundamente humana. Lido como uma parábola, o relato do Éden no Gênesis capítulo três ensina que a humanidade, sob a aparência de um casal único, perdeu a condição querida por Deus, e que ela só terá acesso à salvação com o auxílio de Deus. Para fazer seus correspondentes 
do judaísmo admitirem que só Cristo salva, Paulo lembra que um só (Adão) mergulhou a humanidade no pecado, assimilado a um delito hereditário (...)" (Fouilloux, 1998: 200).

O Antigo Testamento esboça a história do povo hebreu marcada com o pecado original e, por isso, os hebreus esperavam um Salvador que os libertasse, que os livrasse do perigo e da dor, pois sabiam que viria um Messias, conforme narravam as Escrituras. Os primeiros sinais da presença desse Salvador são encontrados nas profecias do profeta Isaías (BíBLIA SAGRADA, Antigo testamento. Isaías 53: 1-8, p. 995), que fala de um homem que carregava as dores do seu povo e que por isso foi oprimido, humilhado, preso e julgado e, ao que tudo indica, para muitos, não para todos, tratava-se de Jesus. A revelação de que Ele seria o Salvador da humanidade aparece então nos textos bíblicos.

A trajetória da vida de Cristo é relatada na Bíblia Sagrada, no Novo Testamento, sobretudo nos evangelhos de Mateus, Marcos, Lucas e João. Cada qual procura representar a via-sacra de Jesus através um tema específico. Mateus traça a vida de Cristo a partir do princípio da presença de Deus no meio dos homens e para ele, Jesus seria "Emanuel, Deus conosco"; Marcos parte da premissa de que Jesus é o Filho de Deus; Lucas estabelece que Jesus é o caminho da salvação; João vê em Cristo um sinal de Deus visto pelos olhos da fé (BíBLIA SAGRADA, Novo Testamento. Introdução aos evangelhos, 1990, p. 1231).

Desta forma, apesar de se tratar do mesmo assunto, cada evangelista orienta a via-crúcis de Cristo direcionando para um determinado tema (Deus conosco, Filho de Deus, caminho e fé).

Para ilustrar a missão de Jesus e justificar sua dolorosa trajetória na Terra, no fragmento acima destacado do evangelho de Mateus, está presente também sua origem: humana porque nasceria de uma mulher, divina porque seria através da "ação do Espírito Santo", ou seja, Cristo - "o Deus humanado" (Padovani; Castagnola, 1956). O Deus que Se faz carne e mora no meio do povo veio para redimir os pecados da humanidade e também ser presença divina na terra e é a partir de sua concepção, que Jesus inicia Sua via-crúcis. 
A vinda de Cristo ao mundo causava medo, principalmente às autoridades. $O$ rei Herodes, por exemplo, com medo de perder o trono para Jesus foi a primeira figura a persegui-lo, mesmo antes dEle nascer (BÍBLIA SAGRADA, Novo Testamento, 1990. Mateus 2: 17, p. 1240). Diante dessa narrativa bíblica é possível considerar a possibilidade de que o percurso da vida de Cristo já estivesse programado por Deus.

Jesus foi morar em Nazaré e lá ficou até retornar a Jerusalém anos mais tarde e dar início à sua vida pública, quando passou a pregar novos conceitos de relacionamentos humanos, como amar o próximo como a si mesmo, ser humilde mesmo quando humilhado, não ser escravo da lei. Esses princípios divergiam do pensamento das pessoas de sua época.

Cristo muda alguns conceitos praticados pelos povos do Antigo Testamento e transforma-os numa prática mais humana e solidária:

\begin{abstract}
Vocês ouviram o que foi dito: 'Olho por olho e dente por dente! Eu, porém, Ihes digo: não se vinguem de quem fez o mal a vocês. Pelo contrário: se alguém lhe dá um tapa na face direita, ofereça também a esquerda (...) (BÍBLIA SAGRADA, Novo testamento, Mateus 5: 38, p. 1244).
\end{abstract}

O fragmento expressa o novo modo de ver o mundo que Cristo disseminava no seu meio: "Vocês ouviram o que foi dito: 'Ame o seu próximo e odeie o seu inimigo! Eu, porém, Ihes digo: amem os seus inimigos, e rezem por aqueles que perseguem vocês!'" (idem, 43).

Num mundo em que as pessoas viviam valores como a vingança e a violência, somente dando se recebessem, Ele propõe um novo modo de pensar e agir, sob novos valores. Por isso, Ele percorria as cidades (Galileia, Cafarnaum, Jericó etc) e povoados, anunciando esse novo modo de viver para as multidões e também para seus discípulos. Estes teriam o mesmo destino do Mestre: cada um passaria pelo caminho da perseguição, sofrimento e dor, pela sua via-crúcis pessoal.

Jesus formou o seu grupo de seguidores entre pescadores, artesãos, pastores e até cobradores de impostos. Não escolheu os mais capacitados 
(doutores da Lei, escribas etc), mas sim aqueles que, com suas práticas, demonstravam humildade e generosidade:

\begin{abstract}
Jesus andava à beira do mar da Galileia, quando viu dois irmãos: Simão, também chamado Pedro, e seu irmão André. Estavam jogando a rede no mar, pois eram pescadores (...) Eles deixaram imediatamente as redes, e seguiram Jesus. Indo mais adiante, Jesus viu outros dois irmãos: Tiago e João (...) E Jesus os chamou (...) Eles deixaram imediatamente a barca e o pai e seguiram Jesus (...) (BÍBLIA SAGRADA, Novo testamento, Mateus 4: 18-23, p. 1242).
\end{abstract}

Em suas caminhadas e peregrinações, Jesus orientava seus discípulos a seguirem seus preceitos, ensinando o amor e a solidariedade entre as pessoas. Isso se contrapunha aos grupos de sua época (fariseus, escribas, saduceus, doutores da lei etc), apegados que estavam às velhas leis e que, por causa delas, deixavam de exercer o bem. Por isso, Jesus os criticava e os chamava de hipócritas e cegos.

Para Jesus, esses grupos político-religiosos formavam uma sociedade de cegos, principalmente os fariseus, que demonstravam superioridade em relação aos outros, por seguirem as leis antigas, exigindo que as pessoas as seguissem, coisa que eles mesmos não faziam. Por isso, Jesus dizia que eles eram cegos. Dessa forma, o ódio que os grupos tinham de Jesus só aumentava. Este foi o motivo de sua perseguição, julgamento, condenação e morte, embora ele já soubesse que, por ser Filho de Deus, devesse passar pelo caminho da dor:

Quando os discípulos estavam reunidos na Galileia, Jesus disse para eles: 'O filho do Homem vai ser entregue nas mãos dos homens. Eles o matarão, mas no terceiro dia ele ressuscitará' (BÍBLIA SAGRADA, Novo testamento, 1990. Mateus 17: 22-23, p. 1262).

Frequentemente Jesus reunia-se com seus discípulos e falava-Ihes a respeito do seu momento doloroso, que em breve ocorreria. No fragmento acima, Ele se coloca como uma pessoa ligada à Terra (filho do Homem) e ao céu, nascido com a predestinação de morrer pelos pecados da humanidade e redimi-la do pecado original, carregado desde Adão e Eva. Em outro momento, em conversa com os discípulos, Ele descreve seu destino com mais detalhes: 
Enquanto subia para Jerusalém, Jesus tomou consigo os doze discípulos em particular e, durante a caminhada, disse para eles: 'Eis que eu estou subindo para Jerusalém, e o Filho do Homem vai ser entregue aos chefes dos sacerdotes e aos doutores da Lei. Eles o condenarão à morte, e o entregarão aos pagãos para zombarem dele, flagelá-lo e crucificá-lo. E no terceiro dia ele ressuscitará' (BÍBLIA SAGRADA, Novo testamento, Mateus 20: 17-19, p. 1266).

Nessa conversa, Jesus especifica aos discípulos como será sua trajetória até a morte. Através dessas colocações, podemos concluir que sua morte ocorreria mesmo sem a perseguição dos grupos opositores a Ele e que seu sofrimento era inerente à Sua vida e missão. Assim, as atitudes dos grupos, bem como a de Judas (o traidor), apenas contribuem para o acontecimento de sua crucificação, que já estaria prevista, desde Sua vinda ao mundo. Esse caminho não foi, porém, uma escolha de Cristo, mas sim uma condição para que ele estivesse na Terra. Sua missão era a remissão dos pecadores, chegando a dizer que "não fosse feita a Sua própria vontade, mas a de Seu Pai" (BÍBLIA SAGRADA, Novo testamento, Mateus 26: 39 p. 1275).

Sabendo de Sua trajetória, Cristo marca um encontro com seus discípulos, o último antes de cumprir a sua sentença:

No primeiro dia dos ázimos, os discípulos se aproximaram de Jesus, e perguntaram: 'Onde queres que façamos os preparativos para comermos a Páscoa?'. Jesus respondeu: ' Vão à cidade, procurem certo homem, e Ihe digam: 'O mestre manda dizer: O meu tempo está próximo, eu vou celebrar a Páscoa em sua casa, junto com os meus discípulos.' Os discípulos fizeram como Jesus mandou, e prepararam a Páscoa. Ao cair da tarde, Jesus se pôs à mesa, com os doze discípulos (BÍBLIA SAGRADA, Novo Testamento, 1990. Mateus 26: 17-20, p. 1275).

O trecho destacado do evangelho de Mateus trata do último encontro de Cristo com seus discípulos, antes da via-crúcis. Os evangelistas contam a mesma história. Com exceção do evangelho de João, que não relata o local do encontro, os demais apontam para a casa de um amigo de Jesus que morava no centro da cidade de Jerusalém ("Ide à cidade"), onde ocorreu o último encontro de Jesus com os seus discípulos, era uma cidade de grande contraste. De um lado o luxo e a riqueza do Templo, de outro a pobreza e a miséria. Alguns tinham muito 
dinheiro, geralmente quem trabalhava com o comércio na cidade, mas os artesãos, tal como Jesus e José, eram pessoas pobres, vivendo do pouco que conseguiam com o artesanato. Por outro lado, Jerusalém era também um centro religioso e local de peregrinação para judeus, muçulmanos e cristãos. ${ }^{7}$

É em meio a esse contexto histórico social, político e religioso, que Cristo ouviu Sua sentença de condenação e sofrimento, sobretudo, porque de alguma forma incomodava os grupos que existiam na Palestina naquela época, que queriam a qualquer custo incriminá-lo por suas pregações:

(...) os chefes dos sacerdotes e os anciãos do povo se reuniram no palácio de Caifás, o sumo sacerdote. Decidiram juntos que prenderiam Jesus com esperteza. E o matariam. Mas diziam: 'Não vamos fazer isso durante a festa, para que não haja confusão no meio do povo' (BÍBLIA SAGRADA, Novo testamento, 1990. Mateus 26: 3-5, p. 1274).

A partir da conversa dos dois grupos opositores (sacerdotes e anciãos), a preparação para a condenação foi tramada devido ao ódio que sentiam por causa das pregações de Cristo, as quais propunham novas maneiras de viver em sociedade, ou seja, o desapego das normas e regras que só levavam sofrimento ao invés de alegria, como pagamento de impostos aos sacerdotes do Templo, exploração da fé dos pobres e viúvas. Práticas essas, condenadas por Jesus, pois Ele via no próximo a possibilidade de viver em fraternidade, segundo relata o texto bíblico. Cristo tinha o próximo como parte integrante de sua pessoa, um eu-pormim e pelo outro (BAKTHIN, apud Clark; Holquist, 1998, p. 138).

$\mathrm{Na}$ época de Jesus, eram celebradas três grandes festas nacionais: a Páscoa, o Pentecostes e as Tendas. Para a celebração destas festas as pessoas peregrinavam até o Templo de Jerusalém. A festa da Páscoa era conhecida como a festa do sacrifício pascal, porque as famílias levavam um cordeiro para ser sacrificado, como forma de pedido de perdão dos pecados a Deus. Era a festa da família e dos amigos, como se nota na atitude de Jesus em chamar os discípulos para cear com ele.

\footnotetext{
${ }^{7}$ Toda a exposição a respeito da terra de Jesus, a Palestina, foi retirada da Introdução ao Novo Testamento encontrada na Bíblia Sagrada, Edições Paulinas, 1990.
} 
No Novo Testamento, há diversas referências à Páscoa de Jesus (morte e ressurreição), mas Jesus, segundo os evangelhos, não foi ao Templo imolar o cordeiro, porque Ele mesmo era o cordeiro pascal que redimiria toda a humanidade. João Batista, ao ver Jesus, revela que Ele é o próprio Cordeiro, aquele que seria imolado: "Eis o Cordeiro de Deus", "o pão da vida" (BÍBLIA SAGRADA, Novo Testamento, 1990. Mateus 26). A expressão de João Batista leva-nos a deduzir que Cristo seria imolado, pois na época de Jesus, durante a Páscoa, toda família levava uma oferta ao Templo, entre todas o cordeiro era a oferta mais preciosa. O cordeiro era o símbolo de imolação.

A Páscoa de Jesus não foi uma simples renovação judaica ou bíblica. Ele celebrou a Páscoa que se referia ao próprio sacrifício dEle, em consonância com a vontade de Deus. No Antigo Testamento, a Páscoa era símbolo e profecia da Nova Aliança; com Jesus, o pão e o vinho se tornariam esses símbolos de sacrifício, os quais, sendo consumidos diariamente, poderiam ser uma indicação de que Jesus estava mostrando aos seus discípulos que a Páscoa deveria ocorrer cotidianamente na vida deles:

\footnotetext{
Jesus tomou um pão e, tendo pronunciado a benção, o partiu, distribuiu aos discípulos, e disse: 'Tomem e comam, isto é o meu corpo'. Em seguida, tomou um cálice, agradeceu, e deu a eles dizendo: 'Bebam dele todos, pois isto é o meu sangue, o sangue da aliança, que é derramado em favor de muitos, para remissão dos pecados' (BÍBLIA SAGRADA, Novo testamento, 1990. Mateus 26: 3-5, p. 1274).
}

Jesus não levou um cordeiro para o sacrifício, mas deu-se a si mesmo, como era da vontade de Deus. O Seu sacrifício cumpriria então o que já estava nas antigas escrituras, como Ele havia revelado ("O Filho do Homem será morto").

Além do sacrifício e aliança com Deus, a Páscoa era considerada popularmente como festa da libertação. As pessoas sabiam que um dos prisioneiros seria libertado da morte na cruz, tal como era o costume da época: "Na festa da Páscoa, o governador costumava soltar o prisioneiro que a multidão quisesse" (Idem, Mateus 27: 15, p. 1277).

A cidade estava em clima de festa e Jesus e seus discípulos estavam reunidos. Esse encontro foi o último antes do início da trajetória da paixão de 
Jesus, ou seja, a de maior sofrimento em sua vida. Nela, Cristo faz uma importante revelação ("O meu tempo está próximo"). A princípio, os discípulos não entenderam essas suas palavras, mas em seguida foi esclarecido o que ele tentava Ihes dizer: "Eu Ihes garanto, um de vocês vai me trair (...) O Filho do Homem vai morrer (...)" (idem, p. 1275).

Essas revelações durante a Ceia Pascal somadas às repreensões aos doutores da Lei e fariseus("Ai de vocês, doutores da Lei e fariseus hipócritas!(...) Ai de vocês guias de cegos!(...) Irresponsáveis e cegos!" (idem, 23: 14-19, p.1270), dão início ao momento mais difícil para Jesus: seu julgamento.

Os escribas, ou doutores da Lei, constituíam um dos vários grupos da época de Cristo, formado por especialistas em direito, administração e educação. Tinham grande influência no Sinédrio (supremo conselho para os hebreus) e por fazerem a interpretação das leis, monopolizavam-nas de certa forma. Os fariseus formavam um grupo de leigos de todas as áreas da sociedade; eram extremamente conservadores e mantinham-se apartados dos outros grupos. ${ }^{8}$

Quando Cristo fez as advertências no Templo, ele se referia às ações desses e de outros grupos, que exploravam a fé dos mais simples para tomar proveito da fragilidade das pessoas. Eram as ações desses grupos que Jesus questionava, e por isso chamava-os de "cegos", ou seja, pessoas que não conseguiam guiar a si próprias e ainda queriam guiar os outros, exigindo que 0 povo oferecesse ao Templo o que não dispunha. Além disso, moldavam a opinião pública, de modo a favorecer seus próprios interesses. Jesus, em suas pregações, conquistava muitos cidadãos, mas também fazia aumentar o ódio por suas ideias: "Ora, os chefes dos sacerdotes e todo o Sinédrio procuravam um falso testemunho contra Jesus(...)"(idem, Mateus 26: 59-67, p. 1276).

\footnotetext{
${ }^{8}$ A respeito dos grupos que existiam na Palestina na época de Jesus, foi consultada a Introdução ao Novo Testamento da Bíblia - Edição Pastoral das Edições Paulinas, 1990, que traz o subtítulo Palestina no tempo de Jesus, p. 1234.
} 
O trecho destacado deixa claro o objetivo dos chefes dos sacerdotes e do Sinédrio em encontrar algum motivo para condenar Cristo à morte. Apesar de acusarem-no de "blasfemador", não era esse o motivo propriamente da condenação, mas sim as denúncias que Jesus fazia no Templo (exploração dos mais fragilizados da sociedade, pobres, viúvas etc). Como os grupos não conseguiam encontrar um motivo criminoso que ofendesse toda a multidão, procuravam de qualquer forma uma maneira de conseguir fazer o povo acreditar que Cristo era um "blasfemador", porque se dizia Filho de Deus.

Percebendo o desejo dos sacerdotes e do Sinédrio em condenar Jesus, Judas Iscariotes (um dos doze discípulos) se uniu a eles:

\begin{abstract}
Jesus ainda falava, quando chegou Judas, um dos Doze, com uma grande multidão armada de espadas e paus. lam da parte dos chefes dos sacerdotes e dos anciãos do povo. O traidor tinha combinado com eles um sinal: 'Jesus é aquele que eu beijar! Judas se aproximou de Jesus, e disse: 'Salve Mestre! E o beijou (...) Então os outros avançaram, lançaram as mãos sobre Jesus, e o prenderam (idem, Mateus 26: 47-51, p. 1276).
\end{abstract}

Quando no último encontro, durante a Ceia Pascal, Cristo falou do traidor, referia-se possivelmente à traição de Judas, que possibilitou e facilitou a sua prisão e condenação. Judas traiu Jesus por dinheiro. A narrativa bíblica não revela se ele era uma pessoa necessitada ou não, mas o fato é que sua ajuda contribuiu para que os chefes dos sacerdotes e anciãos preparassem uma assembleia para condenar Jesus à morte. Ao perceber o que havia feito, Judas sentiu remorso, e como não pôde reverter a situação "saiu, e foi enforcar-se" (idem, Mateus 27: 5, p. 1277).

O remorso de Judas não impediu a condenação de Cristo. Depois de preso, Ele foi levado ao governador da cidade, conhecido como Pilatos, que o interrogou a fim de saber qual era seu crime, depois interrogou também a multidão a respeito do prisioneiro que deveria soltar:

'Tu és o rei dos judeus?' Jesus declarou: 'É você que está dizendo isso' (...) Então Pilatos perguntou: 'Não estás ouvindo? (...) Mas Jesus não respondeu uma só palavra (...). Pilatos bem sabia que eles haviam entregado Jesus por inveja (...). O governador perguntou à multidão: 
'Qual dos dois vocês querem que eu solte? (...) 'Barrabás! (...) Então Pilatos soltou Jesus e o entregou para ser crucificado (...) (idem, Mateus 27: 28-31, p. 1277).

Após escarnecerem de Jesus, entregaram-lhe o instrumento de sua punição: a cruz. Dentre os quatro evangelistas, somente João relata que "Jesus carregou a cruz às costas e saiu" (BÍBLIA SAGRADA, Novo Testamento. João 19: 16 , p. 1383). Nos outros evangelhos não encontramos o verbo "carregar", que fica subentendido. Relatam apenas a saída de Cristo em sua via-crúcis.

Como ficou constatado no quadro bíblico exposto, o encontro de Cristo com os seus discípulos marca um novo momento de sua vida, ou seja, o início de sua dor e angústia, com o caminho que o levaria à morte. No encontro, Cristo revela que seria traído e que morreria. Prevê assim o caminho que percorreria a partir desse momento, pois era o Filho de Deus e sabia que as Escrituras antigas falavam dEle.

As personagens (o primeiro cego, sua esposa, a rapariga dos óculos escuros, o garoto estrábico, o médico e o velho da venda preta) formam, a princípio, o grupo de seis cegos peregrinos ${ }^{9}$, que percorrem os mais variados espaços da narrativa. O termo peregrino permite-nos entender que o grupo caminhará por caminhos desconhecidos e incertos. A partir da formação do grupo dos seis cegos no consultório, aproximamos a atitude de Cristo quando chama os doze discípulos para segui-lo.

Cristo forma seu grupo, diferentemente do que acontece no consultório médico em Ensaio sobre a cegueira, onde o grupo é formado não por uma pessoa, mas através de uma doença insólita nas vistas: a cegueira branca. Todos no consultório procuravam uma solução para o seu problema. Cada texto apresenta um grupo diferente no modo como é formado, mas semelhante na peregrinação.

Outra característica entre os textos é a localização desses encontros. No texto bíblico, como vimos, ocorre na cidade, quando Jesus pede a seus discípulos

\footnotetext{
${ }^{9}$ Utilizamos a palavra peregrino no mesmo sentido da definição do Dicionário de Simbologia de CHEVALIER; GHEERBRANDT, 1999: "A peregrinação se assemelha aos ritos de iniciação: ela identifica com o mestre escolhido" p. 709).
} 
para irem à cidade ("Vão à cidade"). Jerusalém, que vivia um momento importante com a festa da Páscoa, era uma cidade assolada pela desigualdade social e hipocrisia. De um lado, a ostentação do Templo; de outro, a miséria generalizada. Em Ensaio sobre a cegueira, o encontro ocorre no centro de uma cidade, em um consultório médico.

Trata-se de uma cidade não especificada, não identificada sequer em relação ao espaço e ao tempo. É uma cidade que apresenta sinais de organização ("os semáforos", "pessoas aguardavam o sinal de passagem"), mas a tensão é denotada logo na primeira cena: "os automobilistas (...) impacientes (...) mantinham em tensão os carros (...)" (SARAMAGO, 1995, p. 11). Ao que tudo indica, é uma cidade movimentada, prestes a testemunhar um rompimento dessa organização, já expresso pela "tensão dos carros", ou seja, das pessoas que, impacientes, querem continuar seus caminhos.

Em ambas cidades (do romance e do texto bíblico), podemos observar o estado tenso que parece estar prestes a irromper. Para Cristo, porque os grupos já haviam preparado uma forma de pegá-lo e Ele já sabia de tudo: "O Filho do Homem vai morrer" - (BIBLIA SAGRADA, Novo testamento, 1990. Mateus 28, p. 1275). Para as personagens de Ensaio sobre a cegueira, porque a irrupção do estado tenso se dá pelas atitudes dos automobilistas, com gritarias, buzinas e pressa. Parece tratar-se, de fato, de uma cidade moderna, em desenvolvimento expresso pelo movimento contínuo dos carros. Podemos dizer que ambas cidades vivem uma situação de saturação prestes a desencadear uma desordem no que se refere à ordem vigente até então e a apontar para uma nova forma de ordenação.

Nos dois textos, o encontro marca um momento novo para as personagens. Em relação a Cristo, os momentos que antecedem a sua passagem dolorosa na cruz. Observa-se que na narrativa bíblica trata-se do último encontro de Jesus com seus discípulos: "Eu lhes digo: de hoje em diante, não beberei desse fruto da videira". (BÍBLIA SAGRADA, Novo testamento. Mateus 26: 29, p. 1275). Cristo, segundo sugere $\mathrm{o}$ texto bíblico, prevê o caminho que trilharia a partir desse encontro, que é o caminho de sua via-crúcis (dor, sofrimento, queda e morte). Em 
Ensaio sobre a cegueira, o encontro não é o último, mas o primeiro do grupo em relação a um segundo encontro do grupo que ocorre no manicômio, através da narrativa pode-se observar que não foi um encontro planejado, mas sim, casual. Todos no consultório estavam ali por um problema na visão e não se conheciam.

Pela impessoalidade do verbo "havia", expresso pelo narrador, a indicação é a de que ninguém ali se conhecia, diferentemente do texto bíblico, pois Cristo planejou e desejou estar com seus discípulos.

Outro ponto de contato que podemos levantar entre os textos é a presença de um traidor. No texto bíblico tem-se Judas, um dos doze discípulos que, vendo a tensão dos grupos que se opunham à prática de Cristo, vende sua fidelidade por algumas moedas, e depois sente remorso e suicida-se.

Judas é apresentado como uma pessoa fragilizada moralmente, também passa pela sua via-crúcis pessoal. Passa pela dor, sofrimento e morte, como tende a passar, aliás, cada um dos discípulos de Cristo e, do mesmo modo, como as personagens que formam o grupo dos seis cegos peregrinos em Ensaio sobre a cegueira.

Atitude muito semelhante à de Judas tem o ladrão de carros. Depois de o ajudar rouba-Ihe o carro logo em seguida, em seguida desencadeia um processo de remorso, tal como ocorreu com o discípulo de Cristo. Nos dois casos o traidor morre: no texto bíblico, a personagem suicida-se e em Ensaio sobre a cegueira é baleado.

Nesse sentido, a evolução no interior do ladrão pode ser vista como uma via-crúcis pessoal, um caminho de sofrimento e queda, que possibilitou sua transformação ("via-se a si mesmo diferente, outro homem"). Ao se perceber transformado, sentia-se outra pessoa; o remorso, o reconhecimento de suas falhas possibilitou essa mudança. O caminho que tomou, arrastando-se com dor intensa até a guarita onde estavam os guardas, foi um caminho de regeneração interior, que o levou a arriscar-se e por fim, morrer. Assim, tanto Judas como o ladrão vivem um momento intenso de crise existencial, ao perceberem que roubaram e traíram pessoas sem condições de defesa e, da mesma forma, se arrependem e morrem ("censurou-o asperamente por ter sido capaz de roubar 0 
automóvel a um pobre cego", "este homem está morto e é preciso enterrá-lo" (SARAMAGO, 1995).

A ação do ladrão de carros pode ser lida como uma autoajuda, ou seja, a realização de algum bem a si mesmo, como a de Judas. Nos dois casos se pode dizer também que julgam e condenam a si mesmos, porém no texto bíblico Cristo é sentenciado, enquanto que em Ensaio sobre a cegueira, ela traduz um momento de ruptura das relações humanas. Mas em ambos os casos, encontramos 0 remorso e o reconhecimento do erro.

A traição de Judas contribuiu, sim, para o julgamento e a condenação de Cristo por parte de seus opositores, mas também contribuiu, sobretudo, para que ele reconhecesse sua fragilidade humana e se regenerasse. No caso do ladrão, ocorre algo muito parecido. Ao conduzir o cego e logo em seguida ter-Ihe roubado o carro, o ladrão sente remorso ao refletir sobre sua atitude contra uma pessoa incapaz de qualquer reação ou defesa, isso deixa-o sensibilizado durante o passeio que faz com o carro alheio.

É interessante observar que nos dois casos, as personagens não fazem parte do grupo no romance de Saramago o grupo dos seis cegos e da mulher do médico, no texto bíblico dos discípulos de Cristo, em decorrência de suas ações, revelando um certo individualismo quando comparadas às das outras personagens. O ladrão não estava no consultório médio, assim como a mulher do médico, no entanto ela torna-se o centro e guia do grupo, enquanto o ladrão morre.

Em Ensaio sobre a cegueira, a cegueira insólita que acomete, pouco a pouco, todas as personagens (o primeiro caso no cruzamento, o ladrão, a rapariga no hotel etc) e as fazem percorrer o caminho da via-crúcis numa peregrinação constante pelos espaços que compõem a narrativa, pode ser lida como a condenação das personagens, e assim, como Cristo carrega sua cruz às costas e segue seu caminho, as personagens com a cegueira branca percorrem cada espaço como se fossem os passos de uma via-crúcis.

Detivemo-nos no exame do espaço da cidade, o cruzamento da rua (estrada), o consultório médico, o hotel e a casa do médico. Esses espaços nos 
possibilitam estabelecer um quadro de uma cidade com traços de uma possível ruptura espaço-social. Percebe-se o modo gradativo de como as relações interpessoais vão se deteriorando, o primeiro cego em relação à multidão, o ladrão consigo mesmo, a rapariga com as pessoas ao seu redor, e o médico com o governo. O contexto de cunho pessoal se transfere para a cidade como um todo na medida em que vai adquirindo a forma de uma epidemia.

Ao buscar solução para a cegueira branca, o médico sentia-se impotente. Primeiramente, não conseguia descobrir nos livros de que doença se tratava: "depois do jantar vou passar os olhos pelos livros, rever bibliografia, talvez encontre uma pista" (SARAMAGO, 1995, p. 28), e depois, quando procura ajuda junto ao governo:

O ministério queria saber a identidade dos pacientes que tinham estado no dia anterior no consultório, o médico respondeu que as fichas clínicas respectivas continham todos os elementos de identificação (...). Do outro lado o tom foi cortante, Não precisamos (...). As palavras finais foram pronunciadas com expressão formalmente cortês, porém não deixavam qualquer dúvida sobre o facto de serem uma ordem. O médico respondeu, Sim, senhor ministro, mas a ligação já tinha sido cortada (SARAMAGO,1995, p.42).

O fragmento deixa claro ("tom foi cortante", "não precisamos") que o ministério deixou ainda mais evidente a incapacidade do médico em contribuir para a resolução do problema do mal branco. Dessa forma, ele se assemelha à condição de Cristo em sua impotência quanto ao seu destino: "Meu Pai, se é possível, afaste-se de mim este cálice. Contudo, não seja feito como eu quero, e sim como Tu queres" (BÍBLIA SAGRADA, Novo Testamento, 1990. Mateus 27: 40, p. 1275). As duas personagens (Cristo e o médico) são colocadas em condição de subordinação e incapazes de realizarem algum bem a si e a outrem.

No desenrolar das narrativas, encontramos outro ponto de contato com a postura do governo das cidades que surge nos textos. Na narrativa bíblica, Pilatos tenta se colocar diante das multidões em prol de Jesus: "Pilatos perguntou: 'E o que vou fazer com Jesus, a que chamam de Messias?' Todos gritaram: 'Seja crucificado!' Pilatos falou: 'Mas que mal fez ele?' (idem, Mateus 27: 22-24, p. 1277). Jesus contava com a defesa de Pilatos, o governador de Jerusalém na 
época, mas o governador não conseguiu resistir à multidão, insuflada que estava pelos grupos opositores. Não querendo assumir uma postura mais severa, além da que já tinha tomado, Pilatos entrega Jesus ao povo para o julgamento e a condenação.

Em Ensaio sobre a cegueira, a imagem do governo ao tentar solucionar o problema do contágio aproxima-se da personagem de Pilatos no texto bíblico. A semelhança consiste na intenção que cada governo apresenta para evitar um mal maior(em Ensaio sobre a cegueira a epidemia, no texto bíblico a condenação de Cristo). Em ambos os casos, a tentativa do governo de evitar a via-crúcis foi em vão: "O ministério queria saber a identidade dos pacientes que tinham estado no dia anterior no consultório (...) Acabei agora mesmo de saber (...) de dois casos de cegueira súbita (...)" (SARAMAGO,1994, p. 50). No texto bíblico, Cristo é condenado, e em Ensaio sobre a cegueira, os acometidos pelo "mal-branco" iniciam a peregrinação quando levados de suas casas pelo governo. Este, não encontrando outros meios de resolver o problema quando as personagens contraem a doença, tenta outras formas(isolar, orientar as pessoas a fim de resguardar as personagens da epidemia) para conter o alastramento da doença, como a de reunir em quarentena os cegos. Mas como o trecho revela, os casos não paravam e a situação tomava proporções globais na cidade.

A personagem que sobressai em defesa dos cegos é a mulher do médico. Desde o início, ela se prontifica a ajudar o marido, a permanecer ao seu lado em todos os momentos, mesmo quando ele acha que ela não deve. A mulher do médico tornou-se não só a defensora do marido, mas de todos os cegos que encontrou, sobretudo o grupo dos seis.

A pessoa de Cristo projeta a imagem da solidariedade e justiça entre os seus. Na personagem da mulher do médico há algumas semelhanças com a imagem de Cristo no texto bíblico.

Podemos conjecturar, neste caso, sobre uma eventual aproximação entre a figura da mulher do médico e Cristo. Assim como Cristo, também ela aparece como a Eleita, a Escolhida, na medida em que não há razões lógicas ou científicas que expliquem por que não se tornou cega. Além disso, suas atitudes ao longo da 
narrativa revelam que sua visão não é receptiva, mas sim ativa, ou seja, originária do eixo cósmico (ELIADE, 2001), situado no lugar devido, ou seja, seu próprio interior, o que a torna uma figura, no mínimo, próxima do sagrado. Outros pontos de semelhança com Cristo são sua capacidade de liderança, em meio a um grupo social necessitado de solidariedade (semelhantes aos fariseus do Templo), sua prática de vida norteada por valores do espírito e sua compaixão para com os cegos.

Baseados em suas atitudes de solicitude manifestadas pelo marido conjecturamos que os primeiros elementos que nos permitem aproximá-la da figura de Cristo transparecem em seus gestos cotidianos, no preparo da comida, no beijo matinal que dá no marido e se estendem até o momento em que ela alega estar cega apenas para poder acompanhá-lo naquele momento difícil. Convém relermos o episódio em que ela arruma as malas do marido antes de a ambulância chegar:

Ouviu mover-se de um lado para outro, abrir e fechar gavetas e armários, tirar roupas e logo arrumá-las na mala colocada no chão, mas o que ele não podia ver foi que, além da sua própria roupa, haviam sido postas na mala umas quantas saias e blusas, um par de calças, um vestido, uns sapatos que só podiam ser de mulher... (SARAMAGO, 1995, p. 43).

Depois, de malas prontas, ambos esperam a ambulância chegar:

(...) foram sentar-se num sofá da sala, a esperar. Tinham as mãos dadas, e ele disse, Não sei quanto tempo iremos estar separados, e ela respondeu, Não te preocupes (Ibidem).

E, finalmente, quando chega a ambulância:

(...) Desceram no elevador, ela ajudou o marido a transpor os últimos degraus, depois a entrar na ambulância, voltou à escada para buscar a mala, içou-a sozinha e empurrou-a para dentro. Finalmente subiu e sentou-se ao lado do marido. $O$ condutor da ambulância protestou do banco da frente, Só posso levá-lo a ele, são as ordens que tenho, a senhora saia. A mulher, calmamente, respondeu, Tem de me levar também a mim, ceguei agora mesmo (Idem, p. 44). 
Os fragmentos transcritos já trazem fortes indícios(permanência constante ao lado do marido, colocando-se como cega a fim de acompanhá-lo por qualquer lugar que fosse levado) do papel aglutinador que a mulher do médico desempenhará ao longo do romance. Guardadas as proporções e diferenças ela pode ser vista como o Deus humanado (Padovani; Castagnola, 156, p. 138), que assumiu as imperfeições da sua condição humana. Em síntese, o valor máximo é dado à humanidade de Cristo, uma humanidade que é vivenciada, na nossa análise, pela mulher do médico.

Cristo não é o salvador pessoal, mas de toda a humanidade. Queremos dizer com isso, que a mulher do médico está sendo referenciada como guia e orientadora dos cegos, despojando de si mesma, em solidariedade para com aqueles que dela dependiam, tal como relata o texto bíblico em relação à pessoa de Jesus: "Jesus andava por toda a Galileia, ensinando em suas sinagogas, pregando (...) e curando todo tipo de doença e enfermidade do povo" (BÍBLIA SAGRADA, Novo Testamento,1990. Mateus 05: 23-24, p. 1242). As curas e andanças de Cristo nos aproximam da mulher do médico, com seus cuidados para com o marido, seu zelo como visto acima, e logo depois, para com os cegos que guiava.

Continuamos a estabelecer os pontos de contato entre Cristo e a mulher do médico. Assim como Cristo serviu de guia para as pessoas e teve os seus seguidores mais próximos, como Maria Madalena, sua mãe, João, Pedro e os outros discípulos: "Perto da cruz de Jesus, permaneciam de pé sua mãe, Maria de Nazaré, a irmã de sua mãe, Maria, mulher de Cléopas, e Maria Madalena" (BÍBLIA SAGRADA, Novo Testamento, 1990. João 19: 25, p. 1383), assim também ela congrega em redor de si todos os cegos e, especialmente, o grupo dos seis cegos (o primeiro cego e sua esposa, a rapariga, o menino, o médico e o velho da venda preta), com os quais forma, por assim dizer, um grupo diferenciado dos demais, por terem alguém entre eles que via e os guiava, como se fosse os olhos de todos.

Outro ponto de contato entre a narrativa bíblica e Ensaio sobre a cegueira está no fato de os dois textos se referirem à sociedade como uma sociedade cega. 
Cristo chama dura e incessantemente os fariseus de "hipócritas" e "cegos". Para Cristo, a sociedade de sua época não conseguia ver que Deus não queria sacrifícios e holocaustos, mas humildade e amor entre as pessoas. Em Ensaio sobre a cegueira, a cegueira impede que as pessoas vejam as imagens (pessoas, lugares, coisas etc) e as definam; não há possibilidade de decodificá-las, estão todas com a mesma aparência de brancura total.

A cegueira pode estar ligada ao que nos indicam os textos, à perda do conhecimento que não se encontra nos livros, uma espécie de crise do conhecimento, que impede o indivíduo de enxergar aquilo que o rodeia.

A busca do médico, para descobrir de que cegueira seu paciente fora acometido, nos revela que o conhecimento não se encontra mais nos livros, como se acreditava anteriormente. O médico percebe-se impotente diante da situação de cegueira que estava se iniciando em sua cidade.

Um estado semelhante de cegueira é relatado por Cristo, ao observar as ações dos fariseus em relação às normas antigas (não trabalhar aos sábados, jejuar etc) impostas pela cultura da época, não por opção de vida consciente. As normas que eram aplicadas com severidade às pessoas, mas que eles mesmos não seguiam. Por isso, Jesus disse: "São cegos guiando cegos. Ora, se um cego guia outro cego, os dois cairão num buraco" (idem, Mateus 15: 14, p. 1259). Jesus coloca todos na mesma condição, tanto os fariseus que falavam, como os que os escutavam.

Em Ensaio sobre a cegueira, com o alastramento da epidemia criou-se uma imagem ampliada da sociedade de cegos. Vê-se igualmente na narrativa cegos guiando outros cegos e todos caindo e se levantando, como se toda a sociedade vivesse nesse ritmo de queda, que só não é completa porque a mulher do médico torna-se luz para o grupo. E pelo fato de a mulher não ser luz para toda a cidade, nos leva a considerar que a queda só não foi generalizada e a cidade totalmente devastada por que guiado pela mulher do médico o grupo conseguia levantar após as quedas, mais uma vez aproximando-se da imagem de Cristo. É ela quem guia e cuida das pessoas, mostrando novas possibilidades de caminhar, 
restabelecendo as relações interpessoais e respeitando cada um em suas limitações.

Como a cegueira tomava conta da cidade de uma forma inexplicável e rápida, o governo deu início a uma discussão a respeito das providências que deveriam ser tomadas, para que a situação não saísse do controle. Para tanto, procurou resolver o problema utilizando um espaço há muito sem uso: o manicômio, cuja estrutura não permitia nenhum tipo de fuga e, ao que parecia, deixava tranquilo o restante da população. Assim, uma por uma, as personagens foram sendo conduzidas ao que o narrador chamou de "quarentena".

Nesse momento da narrativa de Ensaio sobre a cegueira, parece não haver diferença entre os espaços (ruas, consultório médico ou hotel), que partilham da mesma situação de instabilidade causada pela cegueira. Daí a banalização humana e espacial no sentido de perda de suas potencialidades e finalidades, pois da mesma forma que os espaços não se distinguem, assim também não se distinguem em alguns momentos as personagens, agora cegas, rotas, perdidas na brancura quase total. Os espaços não se distinguem porque suas particularidades foram suprimidas e desarticuladas do contexto da cidade.

A partir do primeiro encontro no consultório, a trama se desenvolve na mesma progressão da cegueira branca e de suas consequências, encaminhandose para um processo de degradação humana e consequentemente espaçotemporal, com o alastramento da epidemia as personagens desorientam-se, a cidade paralelamente entre em um processo de desorganização estrutural e funcional (catástrofes, acidentes e o impacto da imobilidade imposta pelas condições humanas). O encontro, nesse caso, tornou-se o "formador do enredo" (BAKHTIN, 2002, p. 223), na medida que impulsiona a vida das personagens e os acontecimentos que constroem o enredo, da mesma forma como no texto bíblico, onde a partir do encontro tem início o trajeto doloroso de Jesus, através do julgamento e da condenação.

Do cruzamento da rua, onde ocorre o primeiro caso de cegueira, até a atitude do governo em encontrar uma solução para o problema da cegueira branca e seu alastramento, em seguida a vida no manicômio (catástrofes, acidentes 
podemos observar que as relações humanas e espaços-temporais vão revelando o caos que se instaura em uma sociedade desprovida de respeito, generosidade e humanidade.

A deslocação espacial que Saramago revela em seu romance nos remete à análise de L'Assomoir (1876), de Zola, feita por Antônio Candido (2004), onde se constata que as personagens, sem terem para onde ir, após um declínio social, vão morar num espaço tão degradante quanto o inferno: "O cortiço será mais uma espécie de fusão dos demais lugares, um matadouro humano, um fermento de vício, abrigo de bêbados e miseráveis, de doenças e degradações (...)" (CANDIDO, 2004, p. 51).

Muito semelhante a esse espaço analisado por Candido (2004) do romance L'Assomoir (1876), de Zola, nos ocorre ser o espaço do manicômio, que se tornou abrigo dos cegos das mais diversas camadas sociais, unidos pela cegueira, em função da doença, morte e quase que extinção das relações humanas e sociais, vivendo num espaço muito parecido com o inferno, como veremos a seguir. 


\section{O caminho do sofrimento - a segunda etapa da via-crúcis}

No primeiro capítulo, relacionamos o último encontro de Jesus com seus discípulos ao primeiro encontro do grupo dos seis cegos no consultório. Apresentamos o quadro do texto bíblico desde a concepção de Jesus, até os preparativos para o último encontro com os seus amigos, no momento em que Ele é traído por Judas, levado a Pilatos e condenado à morte na cruz. Quanto a Ensaio sobre a Cegueira, focalizamos os primeiros casos de cegueira (do médico, do ladrão e da rapariga dos óculos escuros) e o primeiro encontro, que indicava uma certa ruptura das relações humanas e a consequente desestabilização espaço-temporal.

Neste segundo capítulo, trataremos do tema sofrimento, que consideramos a segunda etapa da via-crúcis das personagens de Ensaio sobre a cegueira, estabelecendo um paralelo com parte do trajeto da vida de Cristo. Em relação a Ensaio sobre a cegueira, enfocaremos o período que se estende desde a entrada dos cegos e da mulher do médico no manicômio, até a saída deles, quando o percurso da via-crúcis toma novo rumo em espaço diferente.

Examinaremos o percurso de sofrimento das personagens e as relações humanas e espaços-temporais no manicômio, lugar que marca o sofrimento ao longo da via-crúcis. Este, ao que tudo indica, se assemelha muito a um mundo apocalíptico, um espaço degradado em sua essência.

Após discutir com os ministros sobre o que fazer com as pessoas "cegas", o governo decide colocá-las em quarentena e, sobre o local ideal para levá-las, diz:

Agora falta decidir onde os iremos meter, senhor ministro (...) De que possibilidades imediatas dispomos, quis saber o ministro. Temos um manicômio vazio, devoluto, à espera de que se lhe dê destino, umas instalações militares que deixaram de ser utilizadas em consequência da recente reestruturação do exército, uma feira industrial em fase adiantada de acabamento, e a ainda, não conseguiram explicar-me porquê, um hipermercado em processo de falência, $\mathrm{Na}$ sua opinião, qual deles serviria melhor aos fins que temos em vista? O quartel é o que oferece melhores condições de segurança, Naturalmente, tem porém um inconveniente, ser demasiado grande, tornaria difícil e dispendiosa a vigilância dos internados, (...) Quanto ao hipermercado, haveria que contar, provavelmente, com impedimentos jurídicos (...) E a feira, a feira 
senhor ministro, creio ser preferível não pensar nela, Porque a indústria não gostaria com certeza (...) Nesse caso, resta o manicômio (...) Pois então que seja o manicômio (...) é o que apresenta melhores condições (...) tem a vantagem de se compor de duas alas, uma que destinaremos aos cegos propriamente ditos, outra para os suspeitos, além de um corpo central que servirá, por assim dizer, de terra-de-ninguém (...) (SARAMAGO, 1995, p. 46).

O fragmento acima esclarece a busca do governo pela solução do problema da "cegueira branca". Após muitos debates, a opção, então, é pelo manicômio, que comporá a primeira quarentena com o primeiro grupo de cegos.

Na esteira do que diz Augé (1994), o manicômio poderia constituir um "nãolugar", um lugar de passagem isento de elos relacionais, identitários e históricos. Mas, que podem ser transformados. O manicômio torna-se, na trama, um lugar representativo, porque ao acolher os cegos em quarentena torna-se um lugar que estabelece elos relacionais, contribuindo para as transformações pessoais. O tempo nele vivido foi, pois, propício às metamorfoses no interior das personagens( mudanças de comportamento, como por exemplo, o sentido materno da rapariga dos óculos escuros, a fragilidade do médico perante uma doença desconhecida, acolhimento dos cegos que chegavam). À medida que o tempo passava, elas foram dando-se a conhecer umas às outras e revelando assim a essência de cada uma.

No texto bíblico, a condenação de Cristo revela o caminho que o leva a viver sob as mais diversas situações de sofrimento. Em ambos os textos, as ações desdobram-se num processo de carnavalização das relações pessoais e espaçostemporais.

O percurso de sofrimento de Jesus é narrado nos quatro evangelhos, qual sejam, de Mateus, Marcos, Lucas e João, respectivamente. Por simples razão didática (clareza na exposição das narrativas), optamos por utilizar o evangelho de Mateus.

No capítulo 27, encontramos todas as passagens que narram os momentos da dor de Cristo até sua morte:

(...) os soldados de Pilatos levaram Jesus ao Palácio do governador, e reuniram toda a tropa em volta de Jesus. Tiraram a roupa dele, e o 
vestiram com o manto vermelho; depois teceram uma coroa de espinhos, puseram a coroa em sua cabeça, e uma vara em sua mão direita. Então se ajoelharam diante de Jesus e zombaram dele, dizendo: 'Salve o rei dos judeus! Cuspiram nele e pegando a vara, bateram na sua cabeça. Depois de zombarem de Jesus, tiraram-lhe o manto vermelho, e o vestiram de novo com as próprias roupas dele (BIBLIA SAGRADA, Novo testamento, 1990. Mateus 27: 27-31, p. 1277).

Após o último encontro e a traição de Judas, Jesus foi levado ao palácio. A partir de então, os soldados, juntamente com seus opositores, zombaram dele e humilharam-no, carnavalizando sua condição de "rei dos judeus". Por isso, colocaram sobre ele o manto vermelho, como se ele fosse uma majestade, um rei, depois da coroa de espinhos - que o colocava entre as piores pessoas da sociedade - e a vara, como se fosse o cajado invertido do rei. A vara também poderia ser lida, segundo transparece do texto bíblico, como um símbolo do pastor, o que Jesus poderia ser, e não rei.

Além dos símbolos de humilhação, os atos de ajoelhar-se diante de Jesus, cuspir e bater nele intentam fazê-lo perder a dignidade, ainda mais por the terem tirado novamente as vestes. Seu sofrimento prossegue na cruz:

Depois de O crucificarem, fizeram um sorteio, repartindo entre si as roupas dele. E ficaram aí sentados, montando guarda. (...) Com Jesus, crucificaram também dois ladrões, um à sua direita e outro à esquerda. (...) Pelas três horas da tarde Jesus deu um forte grito: (...) 'Meu Deus, meu Deus, por que me abandonaste? Alguns dos que aí estavam, ouvindo isso disseram: 'Ele está chamando Elias!' E logo um deles foi correndo pegar uma esponja, a ensopou em vinagre, colocou-a na ponta de uma vara, e deu para Jesus beber (...). Então Jesus deu outra vez um forte grito, e entregou o espírito (...) (BÍBLIA SAGRADA, Novo Testamento, 1990. Mateus. 27: 35-60, p. 1278).

Neste longo fragmento, lemos o intenso sofrimento de Jesus nos últimos momentos de sua vida. Seu martírio se intensifica quando é "despojado de suas vestes" e, logo depois, "pregado na cruz". Depois disso, "morre", é "descido da cruz" e, por fim, "sepultado".

O processo de sofrimento de Jesus ocorreu como Ele já anunciara em suas conversas com os discípulos, antes e durante a Ceia Pascal, ao pressentir seu caminho doloroso. O vinagre, embora utilizado pelos soldados romãs na época de Jesus para anestesiar a dor, no lugar da água, mostra a crueldade dos soldados 
que o tratam desumanamente e com desprezo, Jesus solicitou água e não o alívio da dor. Mas tudo isso ocorreu, como relata o próprio Cristo, para que se cumprissem as Escrituras ("O Filho do Homem vai morrer").

O ápice dessa narrativa ocorre no momento anterior ao da morte quando Cristo dá o último grito ainda na cruz: "Jesus deu outra vez um forte grito e entregou o espírito (...) (Idem, p. 1278). Todos esses fatos (humilhação, sofrimento e dor) ocorreram, segundo indica o texto bíblico, em uma espécie de cemitério chamado Monte Gólgota - lugar das caveiras. Após ter sido tirado da cruz, Cristo é colocado num sepulcro bem fechado ("eles foram manter o sepulcro em segurança: lacraram a pedra e montaram guarda") (BÍBLIA SAGRADA, Novo Testamento, 1990. Mateus 27, p. 1279). O Monte Gólgota representou o lugar de maior sofrimento na via-crúcis de Cristo, o local onde ocorreu seu martírio e sacrifício, cumprindo assim as profecias antigas.

Em Ensaio sobre a cegueira, o segundo percurso da via-crúcis é marcado com intenso sofrimento no manicômio. As personagens passam por um processo de confronto pessoal. À medida que os fatos se desenrolam, vão se revelando as dores de cada um e as dores da coletividade.

A partir do segundo encontro, o grupo iniciará sua via-crúcis unindo-se à mulher do médico, que não estava no primeiro encontro e que, ao agregar-se ao grupo, torna-se a sétima personagem, a única que enxergava, a única também em condições de solidarizar-se com o próximo naquele momento:

A mulher do médico levantou-se, por sua vontade iria ajudar os recémchegados, dizer-lhes uma palavra simpática, guiá-los até os catres, informar, tome nota, este é o sete do lado esquerdo, esse é o quatro do lado direito, não se engane, sim, aqui estamos seis, viemos ontem, sim fomos os primeiros, os nomes, que importam os nomes, um, acho que roubou, outro, que foi roubado, há uma rapariga misteriosa de óculos escuros que põe colírio nos olhos para se tratar de uma conjuntivite, como sei eu, estando cega, que são escuros os óculos, ora, o meu marido é of talmologista e ela foi ao consultório, sim, ele também cá está, tocou a todos, ah é verdade, há o rapazinho que é estrábico (SARAMAGO, 1995, p. 65).

Neste excerto, vemos que o narrador ora assume o ponto de vista da mulher do médico, ora apresenta a preocupação dela em relação a possíveis 
questionamentos do grupo em relação à sua (falsa) cegueira ("Como sei eu, estando cega, que são escuros os óculos"), o que confere tensão à narrativa e aumenta a dramaticidade da cena, porque não estando cega, ela não poderia ficar no manicômio e prosseguir ajudando ao marido e aos outros cegos, embora o tom seja permeado de um sentimento de compaixão e solidariedade. Com a entrada no manicômio, deu-se início à organização do espaço.

A princípio, a vontade de organizar é comum a todos, inclusive por parte do governo, que estabelece as normas de boa convivência para os novos habitantes do manicômio:

(...) pedimos a atenção de todos para as instruções que se seguem, primeiro, as luzes manter-se-ão sempre acesas, será inútil qualquer tentativa de manipular os interruptores, não funcionam, segundo, abandonar o edifício sem autorização significará morte imediata, terceiro, em cada camarata existe um telefone que só poderá ser utilizado para requisitar ao exterior a reposição de produtos de higiene e limpeza, quarto, os internados lavarão manualmente as suas roupas, quinto, recomenda-se a eleição de responsáveis de camarata, trata-se de uma recomendação, não de uma ordem, os internados organizar-seão como melhor entenderem, desde que cumpram as regras anteriores e as que seguidamente continuamos a enunciar, sexto, três vezes ao dia serão depositadas caixas de comida na porta da entrada, à direita e à esquerda, destinadas, respectivamente, aos pacientes e aos suspeitos de contágio, sétimo, todos os restos deverão ser queimados (...) décimo quinto, esta comunicação será repetida todos os dias, a esta mesma hora, para conhecimento dos novos ingressados (...) (SARAMAGO, 1995, p. 50).

O governo tentou, a seu modo, estabelecer a ordem e a organização, mas com o passar do tempo e o aumento constante de cegos que chegavam ao manicômio, as relações pessoais iam aos poucos se deteriorando, juntamente com o espaço e o tempo. Esse processo de deterioração, tanto espaço-temporal como social, cresce à medida que a "cegueira branca" contagia mais e mais pessoas, tornando o espaço do manicômio um mundo ao revés, alheio a toda convenção própria de espaços coletivos, mormente devido à superlotação, falta de organização e de condições adequadas para a manutenção e sobrevivência de todos.

O manicômio torna-se um espaço degradado, a ponto de alcançar o patamar do mais cruel estágio humano. Com a aceleração cada vez maior do 
processo de deterioração, o medo e os horrores vivenciados pelas personagens dão a entender que jamais resistiriam.

Como os primeiros grupos tinham uma noção do espaço das camaratas e dos corredores, tentaram começar a organização pelas camas.

A mulher do médico foi quem ajudou a organizar a entrada dos novos cegos, que chegavam em grande quantidade:

(...) lembrou-se que a maneira mais fácil de encontrar cada um o seu sítio era contar as camas a partir da entrada, As nossas, disse, são as últimas do lado direito (...). O primeiro a avançar pela coxia foi o ladrão (...) Foi indo de cama em cama (...) e quando a reconheceu disse em voz alta, Cá está, e acrescentou, Catorze (...) O primeiro cego foi a seguir. Sabia que a sua cama era a segunda a contar do ladrão, do mesmo lado (...) Aqui a verdadeira casa de cada um é o sítio onde dorme, por isso não se deverá estranhar que o primeiro cuidado dos recém-chegados tenha sido escolher a cama (SARAMAGO, 1995, p. 60, 61, 66).

A partir desse fragmento, é possível verificar a importância da organização do espaço; na impossibilidade de oferecer a cada novo cego um lugar confortável e adequado, ofereciam, então, a cama. A cama, enquanto núcleo acolhedor do ser é uma das poucas possibilidades ainda de alguém se sentir humano, em meio a um espaço caótico e subumano. Essa situação mostra o ponto em que se encontram os cegos no manicômio: em total desorientação e sofrimento; ao que parece, o "inferno" já havia principiado. A situação tomava proporções gigantescas e cada vez mais descontroladas, à medida que o tempo avançava.

Se na imagem do manicômio há uma cidade miniaturizada, na imagem da cama há uma casa miniaturizada. Tida como a imagem do repouso (BACHELARD, 1997), a cama tornou-se o eixo norteador e condutor dos cegos. A redução espacial chega a tal ponto, que a necessidade primordial dos que ali chegava era a de defender o mínimo de dignidade que ainda Ihes restavam, um lugar que não os deixasse perder a identidade.

Assim, a tentativa de organização espacial e os atos de humildade, companheirismo e fraternidade foram, em grande parte, responsáveis pela resistência em meio ao caos que se estabelecera. 
Sobre a questão do caos, os estudos de Alvarez (2008) oferecem recursos para nossa reflexão. O plano narrativo de Ensaio sobre a cegueira que, para a pesquisadora, "se cimenta sobre el mito del dilúvio, o sea, el mito de la recreación" (apud Koleff, 2008, p. 135). O mito da recriação é representado por três símbolos na narrativa: o da cegueira, a que já aludimos; o do batismo, que veremos adiante; e o do caos $^{10}$, que veremos neste capítulo.

Conforme os estudos de Alvarez (2008), o caos em Ensaio sobre a cegueira se dá aos poucos, ou seja, irrompe paulatinamente, à medida que a "cegueira branca" toma proporções globalizadas na vida das personagens. Em suas palavras:

Se introduce, poco a poco, el caos, que propicia vivencias alucinantes, provocadoras de indignación, que acentúan más y más el rebajamiento del hombre, su animalización. Parece el retorno al mundo primitivo (...) Alejadas del contexto urbano y aisladas en un espacio generador de experiencias trágicas, donde los dramas existenciales se tornan cada vez más complejos y terribles, los personajes sienten la urgencia de encontrar salidas. Esta búsqueda se materializa en la recreación de las caminatas por los corredores en demanda de supervivencia y por el intenso sufrimiento vivido ${ }^{11}$ (ALVAREZ apud Koleff, 2008, p. 136).

O caos instaurado no manicômio tomou proporções tão intensas, que a busca por uma solução do problema se dá, propriamente, à medida que as personagens caminham a esmo pelos corredores, que, metaforicamente, podem representar a estrada ou a rua e o manicômio, e por conseguinte a cidade, que ao que tudo indica segue o mesmo processo de degradação.

Para Ribeiro ${ }^{12}$, o caos em Ensaio sobre a cegueira ocorre devido ao fato de a cegueira branca tornar-se gradualmente generalizada. Mas, diante da tentativa de "preservação da ordem"(RIBEIRO, apud LOPONDO, 1998) por parte das personagens, o caos não é absoluto e pode ser relativizado por conta de atitudes de companheirismo e solidariedade das personagens. Por exemplo, a mulher do médico se torna uma mãe protetora e guia dos cegos, enquanto a rapariga de

\footnotetext{
${ }^{10}$ Alvarez (2008) aponta três simbologias que, segundo seus estudos, são usadas por Saramago a fim de desenvolver o mito da recriação.

${ }^{11}$ Grifo nosso.

${ }^{12}$ Professora Doutora Raquel de Sousa Ribeiro - Universidade de São Paulo.
} 
óculos escuros age como mãe do garoto estrábico. Essas atitudes reforçam a resistência ao caos e preservam, de certa maneira, a ordem no manicômio.

Segundo os estudos de Ribeiro ${ }^{13}$, o caráter ambíguo percorre a narrativa mesmo no espaço caótico em que se tornara o manicômio. Essa ambiguidade latente está alicerçada sob "valores todos que apontam para a preservação dos dois polos, emoção e razão harmonizados no homem, para um mundo melhor." (RIBEIRO, Apud Lopondo, 1998, p. 183). O equilíbrio entre emoção e razão possibilita às personagens a resistência prolongada ao caos e a luta pela vida até o último momento:

E agora, como vamos ligar-lhe a perna, perguntou a mulher do médico. Debaixo de uma mesa havia uns quantos panos sujos que deviam ter servido de esfregões, mas seria uma imprudência grave servirem-se deles como ligadura. (...) Mas eu não posso ficar neste estado, senhor doutor, o sangue não para, por favor, ajude-me (...) lamentava-se 0 ladrão. Estamos a ajudá-lo, é o que estamos a fazer, disse o médico, e depois, Dispa a camisola, não há outro meio. O ferido resmungou que lhe fazia falta, mas tirou-a. Rapidamente, a mulher do médico fez com ela um rolo, passou-o ao redor da coxa, apertou com força e conseguiu. (...) Aos pés do garoto alargava-se um charco de urina. (...) Mas como se nada tivesse passado, a mulher do médico disse, Vamos lá então à procura dessas retretes (...) (SARAMAGO, 1995, p. 58).

Os gestos de solidariedade entre as personagens, durante a quarentena, têm a função de aliviar a dor e o sofrimento delas. Na pessoa do médico, há uma vontade de contribuir no sentido de aliviar a dor do "outro". Mesmo cego, o médico não perde seu conhecimento adquirido e, com a ajuda da mulher, supera sua impotência ("Estamos a ajudá-lo, é o que estamos a fazer").

Com o passar do tempo, o aumento do número de contaminados pela "cegueira branca" aumenta incontrolavelmente. A "quarentena" não soluciona o problema, o que torna o espaço do manicômio um depósito de cegos: "Os gritos tinham diminuído, agora ouviam-se ruídos confusos no átrio, eram os cegos, trazidos em rebanho que esbarravam uns nos outros (...) A mulher do médico disse ao marido "O mundo todo está aqui" (SARAMAGO, 1995, p. 102).

\footnotetext{
${ }^{13}$ Artigo intitulado Ensaio sobre a cegueira ou de Brueghel a Seurat (2007).
} 
Percebemos, no trecho, o desconsolo da mulher do médico ao constatar que o espaço já não suportava mais ninguém. Chegavam cegos a todo momento, jovens, crianças, idosos. Enfim, aos olhos da mulher do médico, a epidemia, que a princípio parecia algo passageiro, transmuta-se num estado fixo espalhado por toda a cidade, ou, ao menos, já numa grande parte dela. Assim, o manicômio, com suas janelas altas, corredores estreitos, camas e retretes insuficientes, parecia ter diminuído ainda mais. Não demora muito para que cenas grotescas, as mais baixas possíveis, acabem sendo desveladas:

A mulher do médico, sentada na cama ao lado do marido, disse em voz baixa, Tinha de ser, o inferno prometido vai principiar. (...) Lá no fundo, o médico gritou que havia mais camaratas, mas os poucos que ficaram sem cama tinham medo de perder-se no labirinto que imaginavam, salas, corredores, portas fechadas, escadas que só se revelariam no último momento. (...) Todos os catres estavam agora ocupados (SARAMAGO, 1995, p. 72-73).

No trecho acima, é possível observar que a mulher do médico traduz, com suas palavras, o apocalipse iminente, ou seja, a revelação do "inferno prometido". Parece que a personagem carrega em si uma sensibilidade profética, que entra num processo dialógico com o discurso do narrador. As duas vozes abrem um discurso que nos possibilita aproximar de um discurso labiríntico. No citado trecho, ao que tudo indica, aparece esse tipo de discurso que faz o leitor se perder por algumas falas, devendo ficar atento para resgatar o fio da narrativa, no discurso entrecruzado que parece não ter saída.

Trata-se de um discurso que sinaliza uma possível visão apocalíptica do mundo, desagregado pela falta de relações sociais, onde os cidadãos vivem de maneira desajustada, sob os princípios da irracionalidade. Esse desajuste é representado não só pelo discurso labiríntico, mas também pela condição de intenso conflito das personagens revelada pelos espaços, muitas vezes em situação de limiar (BAKHTIN, 1981), no limite da tensão:

Atenção, atenção, os internados têm autorização para virem recolher a comida, mas cuidado, se alguém se aproximar demasiado do portão receberá um primeiro aviso verbal, no caso de não voltar imediatamente para trás, o segundo aviso será uma bala. Os cegos avançaram devagar, alguns, mais, confiantes, a direito para onde pensavam que devia estar a 
porta, os outros, menos seguros das incipientes capacidades de orientação, preferiram ir deslizando ao longo da parede, assim não haveria enganado possível, quando chegasse ao canto só tinham de seguir a parede. (...) Imperativa, impaciente, a voz do altifalante repetiu a chamada. A mudança de tom, notória mesmo para quem não tivesse sobras de motivos de desconfiança, assustou os cegos. Um deles declarou, Eu não saio daqui, o que eles querem é apanhar-nos lá fora para depois nos matarem a todos, Eu também não saio, disse o outro, Nem eu, reforçou um terceiro. Estavam parados, irresolutos, alguns queriam sair, mas o medo ia tomando conta de todos. (...) A ameaça não venceu o temor, só o empurrou para as últimas cavernas da mente, como um animal perseguido vai ficar à espera duma ocasião para atacar (SARAMAGO, 1995, p.104) .

O excerto acima deixa clara a tensão vivida pelos soldados, postados à sombra do medo e da insegurança da cegueira branca, tensão que ocorre no portão do manicômio. O portão revela um "limiar" pela sua carga de tensão e por demarcar um espaço limítrofe entre um dentro e um fora e, ao mesmo tempo, um espaço de crise e de conflito. A respeito do espaço do limiar, como o portão, conforme o estamos analisando, Bakhtin (1981) diz: "O alto e o baixo, a escada, o limiar (...) assumem o significado de ponto em que se dão a crise, a mudança radical, a reviravolta inesperada do destino, onde se tomam as decisões, ultrapassa-se o limite proibido, renova-se ou morre-se" (BAKHTIN, 1981, p. 171).

A tensão marcada no portão revela o limiar intrínseco, tanto das personagens quanto do espaço, ambos em constante conflito e crise, em meio à insegurança, ao medo e ao terror diante da morte. A tensão não é irradiada somente pelos cegos na quarentena, mas também pelos soldados, que revestidos da missão de conter a epidemia, vivem igualmente a crise e o conflito, como se também fossem cegos.

As situações de crise, como as mencionadas aqui, podem ainda ser lidas como rituais de passagem ou de iniciação ${ }^{14}$, que associam o estado de crise a um estado de busca de equilíbrio, centralidade e à experiência do mundo infernal devido às condições impostas nesse espaço. Nesse sentido, Alvarez (2008) oferece-nos uma valiosa reflexão ao tratar do tema inferno, na literatura clássica europeia, desde os séculos XVII e XVIII, e nas literaturas moderna e contemporânea. Em suas palavras:

\footnotetext{
${ }^{14}$ Abordaremos esses rituais no quarto capítulo deste trabalho e nos apoiaremos nos estudos de Mircea Eliade (2001).
} 
el infierno gana otras formas de registros, tales como la fragmentación del ser, la pérdida de referencias, la marginalización del conflicto dramático. Las situaciones de degradación humana o conflicto interior visten el topos del descenso ad infiernos (ALVAREZ apud KOLEFF, 2008, 136-137).

A experiência do mundo infernal não se dá no campo abstrato, mas sim no campo concreto, materializando-se nas ações das personagens que vivem em situações limites, quase insuportáveis, como a mulher do médico, por exemplo, que, após matar o cego ladrão, titubeou algumas vezes, martirizando-se ao pensar no juízo que fariam dela ao saber que matara alguém:

Depois pensou, levantando os olhos, E se agora lhes dissesse que fui eu que matei, entregar-me-iam sabendo que me entregavam a uma morte certa. Fosse por efeito da fome ou porque o pensamento subitamente a seduziu como um abismo, variou-lhe a cabeça uma espécie de aturdimento, o corpo moveu-se-lhe para diante, a boca abriu-se para falar, mas nesse momento alguém agarrou e apertou o braço, olhou, era o velho da venda preta, que disse, Mataria com as minhas mãos quem a si próprio se denunciasse, Porquê, perguntaram da roda, Porque se a vergonha ainda tem algum significado neste inferno em que nos puseram a viver e que nós tornamos em inferno do inferno ${ }^{15}$, é graças a essa pessoa que teve a coragem de ir matar a hiena ao covil da hiena (SARAMAGO, 1995, p. 191).

Por meio do diálogo presente no excerto acima, a personagem revela que o manicômio se tornou o inferno, no sentido de que a experiência do caos, em seu estágio mais avançado, coloca todas as personagens em estado de crise existencial e de valores, a qual aumenta à medida que o tempo passa e o problema da cegueira branca continua sem solução.

O tempo tornou-se uma das grandes preocupações das personagens. À medida que ele se prolonga, a exaustão dos cegos aumenta, da mesma forma que propicia a transformação nas relações sociais e interpessoais. A preocupação das personagens fica evidente, pois conforme o tempo passa, mais distantes elas se sentem do mundo. É como se a própria vida se extinguisse:

O tempo foi passando. Cansados de esperar, alguns cegos tinham-se sentados no chão (...) (SARAMAGO, 1995, p. 88).

\footnotetext{
${ }^{15}$ Grifo nosso.
} 
(...) cada coisa chegará no tempo próprio, não é por muito ter madrugado que se há de morrer mais cedo (...) porque permitirá saber, em qualquer momento, o que foi feito e o que está por fazer, é como olhar um relógio e dizer do dia que passa, Vivi desde aqui até aqui (...) (Ibidem, p. 169).

Nos trechos selecionados, as personagens demonstram o esgotamento diante do tempo que passa, a intensificação da fragilidade diante da situação. Os fragmentos aludem a uma certa desilusão em relação ao tempo de vida que ainda teriam, revelando uma espécie de nostalgia da própria existência.

Outra análise que podemos fazer do tempo, enquanto integrante da estrutura do enredo, é que se trata de um tempo de transformação, já apresentado por Bakhtin (2002) no exame de romances desde a antiguidade, representado pelos cronotopos do encontro e da estrada. As transformações ocorridas nas personagens no espaço do manicômio podem ser tratadas como transformações profundas, não só pela experiência de sub-humanidade pela qual passam, mas, sobretudo, pela experiência de renovarem-se interiormente.

O estudo do tempo não pode, dessa forma, ser analisado separadamente do espaço, o que nos leva a tratar o manicômio como um "cronotopo" (Bakhtin 2002), onde as relações tempo e espaço se encontram entrelaçadas e harmonizadas entre si, formando um núcleo inseparável.

À medida que o tempo passa e o problema da cegueira branca permanece sem solução, a situação de caos prossegue. As personagens estão imersas na degradação quase total, vivendo da forma mais grotesca possível, em um mundo que mais se assemelha ao inferno das relações humanas e sociais:

(...) os primeiros cegos trazidos a esta quarentena foram capazes, com maior ou menor consciência, de levar com dignidade a cruz da natureza eminentemente escatológica do ser humano. Mas agora, ocupados como se encontram todos os catres (...) nenhuma imaginação (...) poderia descrever com propriedade o estendal de porcaria que por aqui vai. Não é só o estado a que rapidamente chegaram as sentinas, antros fétidos, como deverão ser, no inferno, os desaguadoiros das almas condenadas, é também a falta de respeito de uns ou súbita urgência de outros que, em pouquíssimo tempo, tomaram os corredores e outros lugares de passagem em retretes que começaram por ser de ocasião e se tornaram de costume. (...) Quando se tornou impossível (...) chegar aonde estavam as sentinas, os cegos passaram a usar a cerca como lugar para todos os desafogos e decomposições corporais. (...) lá iam, agarrados à barriga ou apertando as pernas, à procura de três palmos de chão limpo, se os havia entre um 
contínuo tapete de excrementos mil vezes pisados (...)" (SARAMAGO, 1995, p. 133, 134).

Os elementos (excrementos, decomposições corporais) contidos neste longo fragmento nos revelam a condição do grotesco, presente no romance. Segundo Bakhtin (1987), o grotesco está ligado ao princípio da vida material e corporal: imagens do corpo, da bebida, da comida, da satisfação de "necessidades naturais" e da vida sexual.

No entanto, essas imagens se mostram hiperbólica e abundantemente ("o estendal de porcaria", "antros fétidos", "contínuo tapete de excrementos mil vezes pisados") no romance; assim, o princípio material corporal aparece de forma universal. Os aspectos do grotesco estão ligados à dimensão "carnavalesca do mundo", ou seja, do mundo em ordem inversa à do cotidiano, e as imagens grotescas se caracterizam como "um fenômeno em estado de transformação"; daí o caráter do inacabado do "devir", que implica um estranhamento, no limite da existência:

(...) a imagem grotesca caracteriza um fenômeno em estado de transformação, de metamorfose, no estágio da morte e do nascimento, do crescimento e da evolução. Seu segundo traço indispensável decorre do primeiro, é sua ambivalência: os dois pólos da mudança (o antigo e o novo, o que morre e o que nasce, o principio e o fim da metamorfose) são expressos (ou esboçados) em uma ou outra forma (BAKHTIN, 1987, p. 21).

Ao que tudo indica, as personagens passam pelo "fenômeno de transformação", à medida que vivenciam as mais diversas situações de morte e de vida, de sofrimento e de solidariedade, que contribuem para transformações coletivas ao longo do desdobramento da narrativa.

No cerne de Ensaio sobre a cegueira pode haver a indicação de uma nova postura de relações entre as pessoas, de uma sociedade desapegada do individualismo, que agrega em si novas práticas de relações humanas e sociais, baseadas no respeito e na ética.

Mesmo diante do caos é preciso estabelecer novas formas e novos critérios baseados nas relações entre o "eu" e o "outro". Novos critérios, ao que parece, são estabelecidos, sobretudo através dos seis cegos e da mulher do médico, que 
juntos dividem suas histórias e seus medos, ajudando-se mutuamente no que era possível. O médico tornou-se um pai; sua mulher, os olhos do grupo. Curam, ajudam, dando-se ao outro, e a rapariga dá-se a conhecer como uma mulher zelosa e materna. Enfim, na medida do possível, estabelece-se a amizade e a solidariedade no grupo, que não se estende ao universo do manicômio, pois com a chegada de novos cegos surgiram novos líderes, porém antagonistas, ou seja, líderes do mal, ladrões, como podem existir em qualquer sociedade. Ao perceberem a fragilidade dos cegos que estavam no manicômio, os cegos ladrões impuseram uma nova ordem, pela qual seriam eles os novos "chefes", fato que deu início a grandes embates entre os grupos.

O primeiro embate ocorre depois que os cegos ladrões exigem todos os bens materiais dos outros cegos. A maior luta se dá, quando esses bandidos resolvem afrontar a decência e a dignidade das mulheres que ali estavam, obrigando-as a satisfazerem suas necessidades sexuais: "Quantas mulheres têm vocês aqui, perguntou um deles. (...) Somos sete (...) então vão ter de trabalhar muito esta noite (...) são três homens para cada mulher, elas aguentam (...)" (SARAMAGO, 1995, p. 173).

De acordo com o que observamos nesta parte da narrativa, está muito clara a presença de uma das características do grotesco, em relação a um de seus elementos, que é a questão sexual. No entanto, não se trata de um grotesco satírico, como o da Idade Média, mas o do período romântico da literatura, que é carente do elemento riso, o que torna horrendas as imagens grotescas, causadoras de pavor e medo diante das imagens exageradas (BAKHTIN, 1987).

Vemos que o manicômio já está completamente tomado pelo caos, a degradação parece ter chegado ao seu limite. O inferno parece concretizado na imagem das mulheres sendo abusadas e moralmente massacradas:

Amanhecia quando os cegos malvados deixaram ir as mulheres. A cega das insônias teve de ser levada dali em braços pelas companheiras. (...) Durante horas haviam passado de homem em homem, de humilhação em humilhação, de ofensa em ofensa. (...) Está morta, disse a mulher do médico. (...) Vão buscar a comida. (..) Fiquem aqui, eu já volto. (...) Queria um balde (...) enchê-lo de água, ainda que fétida, ainda que apodrecida, queria lavar a cega das insônias, limpá-la do sangue e do 
ranho alheio, entregá-la purificada à terra (...) sete mulheres nuas, a cega das insônias estendida na cama, limpa como nunca estivera em toda sua vida, enquanto outra mulher lavava, uma por uma, as suas companheiras, e depois a si própria (Ibidem, p. 173-181).

Esse longo trecho revela o nível a que chegou o espaço do manicômio. As personagens parecem ter alcançado o ápice da decadência humana. $\mathrm{O}$ grotesco e o insólito carnavalesco revelados pela atitude dos cegos ladrões, ao abusarem das mulheres, o cenário pavoroso e exagerado, são amenizados pela atitude "religiosa" da mulher do médico (ao lavar a cega das insônias, por exemplo), ao realizar um ritual de iniciação ou de passagem (ELIADE, 1989), pelo qual as pessoas precisam passar para pertencerem a um determinado grupo, ritual em que elas experimentam o sofrimento, a dor e a morte até renascerem, revigoradas, para uma vida nova.

A atitude da mulher do médico pode ser associada ao ritual de purificação referido por Eliade (1989). Leva-nos a inferir que ela porta em si algum sinal distinto das outras mulheres. Sua preocupação mítica em lavar e preparar aquele corpo que a Terra-Mãe abrigaria em uma nova vida, como se fosse um renascimento num espaço também mítico, que é o centro do cosmos, revela o misticismo de seu ato. O banho ritualístico iniciático é fonte de imortalidade, de regeneração, ou seja, de um novo nascimento.

O confronto entre os horrores e a vitória forma a base do ritual de iniciação. A morte iniciática, que pode ser representada pela cega das insônias, poderia ser uma espécie de retorno ao caos para a preparação do novo nascimento, como nos apresenta Eliade (1989).

Já na Idade Média, os cavaleiros eram iniciados através do banho, antes da sagração. Era um costume muito antigo, que aparece sob inúmeras formas, nas mais variadas culturas. Porém, em todos os casos, está relacionado à questão do renascimento, dentro de uma certa perspectiva entre vida e morte, com o surgimento de um homem novo. Assim, as religiões cristãs, ao procederem ao ritual do batismo, passam por este mesmo processo de renovação (CHEVALIER; GHEERBRANDT, 1999). 
A imortalidade presente na ação do banho ritualístico e a questão da iniciação do ser, junto a um novo grupo, ou a uma nova vida, nos leva a refletir sobre o número sete, formado pelo grupo das mulheres.

$\mathrm{Na}$ simbologia, o número sete trata da totalidade do ser e do mundo. Sua presença é bastante forte nos rituais sagrados, em que a presença divina se faz concreta, espécie de junção entre a cosmogonia, a sacralidade e a humanidade (idem).

As sete mulheres que satisfizeram os homens nos fazem lembrar do grupo dos "sete peregrinos", como observamos anteriormente, e que reaparece agora, sendo que, em ambos os casos, a mulher do médico tem uma função de extrema importância por estar sempre no centro, como que unindo os outros seis integrantes ao restante do mundo.

No livro do Apocalipse também existe a presença muito forte da simbologia do número sete, o qual guarda em si um segredo ou um mistério. Por isso, ligada à palavra "Apocalipse" está o conceito de "revelação por meio de sinais". Os sinais que o profeta João viu: as sete igrejas, as sete velas no candelabro, as sete estrelas, os sete flagelos... Todos esses símbolos ligados à conclusão cíclica e à renovação cosmogônica.

O sete é símbolo de um ciclo positivo, na maioria das vezes. Os sete graus da perfeição, de mudança em multiplicação, rumo ao infinito. Também se refere às virtudes teologais e cardeais: a fé, a esperança, a caridade, a prudência, a temperança, a justiça e a força (CHEVALIER; GHEERBRANDT, 1999).

Parece-nos que, ao referir-se ao número sete, Saramago alude a toda esta simbologia de renovação e virtudes, à totalidade da essência humana e à sua integralidade, reveladas à medida que o grupo percorre cada trajeto da via-crúcis. Assim, os rituais iniciáticos e a simbologia do número sete nos encaminham para o processo de renovação cosmogônica que as personagens revelam com suas atitudes e ações, cada qual com uma missão dentro do grupo, a despeito da quase total deterioração do espaço social apresentado no desenrolar da narrativa.

O Apocalipse é marcado pela presença do número sete, que aparece também em outros livros bíblicos, como no Evangelho de Mateus, no relato da 
multiplicação dos sete pães e quando Jesus se refere ao perdão. Também aparece nos outros evangelhos. No livro de Gênesis, encontramos a narrativa da Criação, segundo a qual o Criador trabalhou seis dias e descansou no sétimo, o que aponta para o ciclo completo: a totalidade do espaço e do tempo, uma perfeição dinâmica (CHEVALIER; GHEERBRANDT, 1999).

Há, na simbologia do número sete, uma centralidade bem marcada, pois existem sempre seis iguais e um diferente, o que nos faz pensar que Saramago teria utilizado este número no romance, para justamente indicar a centralidade ligada à personagem da mulher do médico, pois no grupo das mulheres, ela era justamente a sétima, a única que enxergava. No grupo dos escolhidos, ela também estava marcada com o diferencial: os seis cegos e ela no centro, como guia.

O sete está ligado, ainda, ao tempo da peregrinação terrena do homem, segundo Santo Agostinho (idem, p. 828). Esse tempo de peregrinação nos chama a atenção pelo fato de estarmos tratando de um grupo que percorre uma viacrúcis, ou seja, uma peregrinação que, simbolicamente, remete a toda a humanidade em constante movimento, em busca da integração ao seu mundo, com o intuito de restabelecer as relações de humanidade que, em sua essência, precisaria de uma "ressacralização" (ELIADE, 2001), ou seja, de uma renovação e resgate de conceitos basilares na construção de uma sociedade mais agregada em si mesma, uma forma de luta constante contra a violação dos direitos inerentes ao ser humano. Essa luta é representada pelo grupo das sete personagens, sobretudo pela mulher do médico.

Após os estupros que, do nosso ponto de vista, constituem o clímax dessa etapa da via-crúcis, ocorre a cena em que a mulher do médico, num instinto de indignação, decide assassinar o cego ladrão da pistola, chefe do bando:

(...) a mulher do médico observava os movimentos daquele que não tardaria a matar. (...). A mão levantou-se lentamente a tesoura. (...) A tesoura enterrou-se com toda força na garganta do cego. (...) Sim, mateio eu, Por quê, Alguém teria de o fazer (...) se quiserem outra vez servirse de nós, Vai haver luta, guerra (...) (SARAMAGO, 1995, p. 185-189). 
Sua atitude pode ser vista como uma paródia do ideal de cavalaria da Idade Média. É uma espécie de paródia carregada de ironia, pois a tesoura em suas mãos nos lembra, de modo subvertido, a espada nas mãos dos cavaleiros medievais. Ao cavaleiro era dada a espada para que pudesse manter a justiça e preservar o direito. No momento do ritual da entrega, a espada tornava-se a imagem de uma cruz. Ironicamente, a arma utilizada pela mulher do médico é uma tesoura que, aberta, toma a forma de duas lanças em um formato de cruz, assim como a espada do cavaleiro medieval.

$\mathrm{Na}$ Idade Média, o tempo de aventura da vida cotidiana mantinha uma relação com a sacralidade da visão do mundo, decorrente do respeito ao código ético em que se baseava, ou seja, agir somente se houvesse necessidade. E essa necessidade era recorrente, pela falta de justiça e constante violação dos direitos; por isso, era dado ao cavaleiro o direito de usar sua espada. (RAGACHE, Claude Catherine; PHILIPPS, Francis, 1993).

Da mesma forma, a tesoura nas mãos da mulher do médico pode ser vista como uma maneira de restabelecer a ordem, a justiça, o respeito e o direito de ser, em um mundo caótico e deteriorado pelo desrespeito e pela injustiça. Assim, quando ela mata não infringe o código ético, não banaliza a morte, mas age por necessidade extrema de restituir a dignidade dos cegos. Talvez seja esse o motivo pelo qual ela não tenha perdido o sinal de sacralidade que, de acordo com nossa reflexão, carregava.

Assim como a mulher do médico agiu em defesa da justiça, outra personagem teve gesto semelhante. Era uma mulher que havia chegado há pouco no manicômio e que atiçou fogo na camarata dos cegos ladrões. Contudo, nesse último caso, a mulher foi consumida por seu ato:

(...) na pessoa de uma mulher que, mal entrou na camarata (...) se pôs a remexer nos seus trapos até encontrar um pequeno objeto (...) que apertou na palma da mão (...) tendo-se lembrado que trouxera um isqueiro. (...) A mulher está de joelhos à entrada da camarata, mesmo junto às camas, puxa devagar os cobertores para fora (...) agora é só chegar-lhes o fogo. Ainda se recorda de como deverá regular o isqueiro para produzir uma chama comprida. (...) Começa pela cama de cima, a labareda lambe trabalhosamente a sujidade dos tecidos, enfim pega, agora a cama do meio, agora a cama de baixo (...) a mulher sentiu o 
cheiro dos seus próprios cabelos chamuscados (...) o fogo anda a saltar velozmente de cama em cama (...) a mulher do isqueiro (...) está calada há muito tempo (Ibidem, p. 205, 206, 207).

A respeito do gesto da mulher que atiça fogo na camarata dos cegos ladrões, os estudos de Alvarez (2008) nos ajudam a entender o gesto como um rito sacrificial, pois ao atiçar o fogo, ela possibilita a continuidade da vida dos outros cegos e consome-se nas chamas. Um sacrifício em decorrência de outro; ela morre, mas garante que a vida dos cegos prosseguirá.

Já a atitude da mulher do médico a coloca em igualdade com os cegos ladrões, por sua coragem de matar, e nesse sentido ela é, aparentemente, "destronada" de seu papel de mulher sensata e racional. O destronamento é uma característica carnavalesca, o rei torna-se "bufão", o empregado o patrão, ou seja, as personagens invertem os papéis, distanciando-se da normalidade do cotidiano (BAKHTIN, 1987).

No entanto, como a morte por ela provocada não significa va a banalização da vida, mas sim, uma busca pela justiça, esse destronamento parece ter ocorrido apenas naquele momento e, logo, ela restaura sua sublimidade, prosseguindo em sua missão de guia dos cegos, dando continuidade à via-crúcis de seu grupo.

Após o assassinato do cego ladrão e do incêndio no manicômio, a vida das personagens atacadas pelo mal branco toma um novo rumo. O manicômio chega ao seu fim, pois o fogo o consumiu parte por parte, ilustrando uma espécie de inferno na trama. Assim, a mulher que atiçou o fogo e por ele foi consumida não pôde ver o bem que fez aos que ali estavam de quarentena. O fogo se alastrou, tomou conta de todo o manicômio, devorou como faminto o seu pedaço de pão:

(...) então de repente as chamas multiplicaram-se, transformaram-se numa única cortina ardente, um jorro de água ainda passou através delas, foi cair sobre a mulher (...) o fogo anda a saltar velozmente de cama em cama, quer deitar-se em todas ao mesmo tempo (...) a maior parte do edifício do outro lado é já uma fogueira (...) (SARAMAGO, 1995, p. 207-208).

A destruição do manicômio nos remete ainda a um texto bíblico que descreve duas cidades que viviam em total desordem, com adoração de falsos 
profetas, em meio a orgias e sacrilégios, quando Deus, em Sua ira, cumpriu a promessa:

O sol estava nascendo quando Ló chegou a Sigor. Então Javé fez chover do céu enxofre e fogo sobre Sodoma e Gomorra. (...) Abraão levantou-se de madrugada e foi ao lugar onde estivera com Javé. Olhou para Sodoma e para Gomorra e para toda a planície e viu a fumaça subir da terra, como a fumaça de uma fornalha (BÍBLIA SAGRADA, Antigo Testamento, 1990. Gênesis19: .23-24, 27-28).

Assim como o manicômio, as cidades de Sodoma e Gomorra tornam-se cinzas, em total destruição.

No texto bíblico, vemos que Ló foi poupado de ser consumido pelas chamas com os seus, pois era um ser temente a Deus e justo, marcado com sinais de sacralidade. Assim também ocorre no romance, quando a mulher do médico e o seu grupo são poupados de serem consumidos pelas chamas, o que nos leva a refletir que este grupo teria um sinal diferenciado dos demais.

Além da estilização que consiste na presença de elementos e funções semelhantes em narrativas distintas (fogo, destruição e personagens poupadas) (Bakhtin, 1981) do texto bíblico, o fragmento ainda nos remete a um outro texto, que se refere na Mitologia à lenda da Fênix, na qual também parece ocorrer a técnica da estilização. O elemento "fogo", tal como se apresenta em ambos os textos citados e utilizados em Ensaio sobre a cegueira, promove um discurso intertextual, permitindo-nos lê-lo como um símbolo de possível libertação da "cegueira branca".

O fogo faz parte de um dos elementos essenciais da matéria, trazendo em si certa ambivalência, embora seja o mais inovador de todos. Ele é encontrado há milhares de anos na história do homem, bem como na história da literatura. Para Bachelard (1997), a lenda da Fênix é a sublimação absoluta, a abertura à transcendência, ao "vir-a-ser" e ao ressurgir; e a morte nas chamas, para ele, é a menos solitária das mortes, pois, neste sentido, nunca se morre sozinho. Podemos conjecturar que a morte da cega que colocou fogo nas camaratas possui de certa forma a transcendentalidade da ave, pois ela não morreu sozinha, mas com as camas, colchões, vidros, janelas, outros cegos e com as chamas. 
A respeito da lenda da Fênix, Chevalier e Gheerbrant dizem:

A Fênix, segundo o que relatam Heródoto ou Plutarco, é um pássaro mítico, de origem etíope, de um esplendor sem igual, dotado de extraordinária longevidade, e que tem o poder, depois de se consumir em uma fogueira, de renascer de suas cinzas. Quando se aproxima a hora de sua morte, ela constrói um ninho de vergônteas perfumadas onde no seu próprio calor se queima. Fênix é o símbolo da ressurreição, que aguarda o defunto depois do julgamento das almas e se ele houver cumprido devidamente os ritos e sua confissão negativa for julgada como verídica. É por isso que toda a Idade Média fez da Fênix o símbolo da ressurreição de Cristo. (...) A Fênix é considerada também como símbolo da cidade do sol. (...) Diz a lenda que quando a Fênix sente sua morte iminente, depois de fazer a pira canta com voz lamuriosa e intensamente triste que leva outras aves à morte. Após a consumação de seu corpo na fogueira, ressurge uma nova ave, jovem, forte, tão bela quanto a consumida pelo fogo (1999, p. 421,422).

O ritual que envolve a lenda da Fênix nos faz pensar nas ações da mulher que atiçou o fogo, cujo procedimento se assemelha ao da ave ("fez a pira", "atiçou o fogo"), a preparação para o início do ritual da libertação, através do fogo. A ave liberta-se da vida velha, enquanto a mulher liberta os cegos do mundo caótico em que se tornara o manicômio. A imagem da ave renovada e forte nos leva a refletir também acerca do ritual de iniciação (ELIADE, 1989).

O grupo das sete personagens pode representar a humanidade ali presente, que, logo depois, renasce das cinzas, assim como a ave, totalmente renovada e purificada e, ao ressurgir, conquista uma vida nova.

Após a caminhada no segundo percurso da via-crúcis das personagens no manicômio, que marca o intenso sofrimento pelo qual elas passam, podemos retornar ao texto bíblico para estabelecer possíveis pontos de contato entre os dois textos.

Em Ensaio sobre a cegueira, o segundo percurso da via-crúcis ocorre no manicômio: "És capaz de imaginar aonde nos trouxeram, Não, ela ia acrescentar A um manicômio, mas ele antecipou-se" (SARAMAGO, 1995, p. 48). Longe da cidade, estrutura fechada e "segura", difícil de haver algum tipo de fuga, como narra o representante do governo, "dividido em alas", "janelas e muros altos", era o lugar ideal para a "quarentena". A palavra manicômio sugere um lugar onde ficam 
isoladas pessoas "alienadas" ${ }^{16}$, que, em síntese, passaram algo aos cuidados de alguém. No caso dos cegos, estão à mercê da vontade alheia, do governo, nesse caso específico.

As personagens que cegam de repente e são levadas para o manicômio não apresentam sinais de doença ou confusão mental, mas sim, de um problema de visão. Possivelmente estavam sendo tratadas como "alienadas". No caso, a cegueira branca seria uma espécie de alienação social, com as pessoas impossibilitadas de guiar e de ver a si próprias e, consequentemente, de se relacionarem entre si, apesar de estarem em um mesmo espaço que, à medida que o tempo passa, deteriora-se gradativamente.

Em paralelo ao manicômio de Ensaio sobre a cegueira, o texto bíblico apresenta o lugar de maior sofrimento de Cristo, o "lugar das caveiras" - Gólgota (em aramaico), que significa lugar do sofrimento, suplício, martírio, calvário (BÍBLIA SAGRADA, Novo Testamento, 1990. Mateus 27: 33, p. 1278). Localizado em uma montanha, longe da cidade, o Gólgota foi o cenário do percurso dolorido na trajetória de Jesus. Em relação ao manicômio, ambos ficam longe da cidade. Gólgota, um espaço aberto; manicômio, um espaço fechado. Fisicamente, esses dois lugares são diferentes, mas a vivência em ambos é muito semelhante: dor, sofrimento, angústia.

No texto bíblico, o Gólgota representou os resquícios de vida e de humanidade de Jesus. Em Ensaio sobre a cegueira, o manicômio pode ser comparado a um lugar também de martírio, suplício e calvário das personagens que tentam sobreviver às provações vividas nesse momento da trajetória.

A presença dos soldados, em ambos os textos, sinaliza o cumprimento de uma ordem na trajetória das personagens. No texto bíblico, os soldados protagonizaram a zombaria e a tortura de Jesus ("os soldados (...) tiraram a roupa dEle"). Em Ensaio sobre a cegueira, eles cumpriram a ordem do governo de manter afastados os cegos e, se fosse preciso, de matar ("Os dois soldados da

\footnotetext{
${ }^{16}$ Estamos empregando a palavra alienadas conforme as definições do Dicionário Houaiss da Língua Portuguesa
} 
escolta, que esperavam no patamar, reagiram exemplarmente, perante o perigo (...) despejaram os carregadores") (SARAMAGO, 1995, p. 88).

$\mathrm{Na}$ imagem dos soldados, encontramos o cumprimento da lei, que não necessariamente seria uma vontade pessoal deles. Em Ensaio sobre a cegueira, eles agem com medo, medo de represálias do governo e medo de se contagiarem; no texto bíblico, pelo medo da multidão.

$O$ percurso de sofrimento na vida de Jesus era esperado, porque foi revelado desde as escrituras antigas ("O Filho do Homem vai morrer") (BÍBLIA SAGRADA, Novo testamento, 1990. Mateus 27, p.1278). Em Ensaio sobre a cegueira, a profecia da mulher do médico foi uma constatação de um apocalipse que pressentia iminente ("A mulher do médico, sentada na cama ao lado do marido, disse em voz baixa. Tinha de ser, o inferno prometido vai principiar") (SARAMAGO, 1995, p. 72).

Tanto Jesus como a mulher do médico profetizam o caminho de sofrimento e dor por qual passariam, e não somente os dois. Na narrativa bíblica, os discípulos de Jesus estavam fadados ao mesmo caminho de sofrimento e, da mesma forma, os seis cegos guiados pela mulher do médico em Ensaio sobre a cegueira.

Outro ponto de contato neste percurso é a constituição de um grupo formado pelos discípulos e guiado por Jesus no texto bíblico. Em Ensaio sobre a cegueira, o grupo é formado pelos seis cegos e pela mulher do médico, que tem o papel de guia, tal como Jesus na narrativa bíblica. Os dois grupos são unidos e ligados por gestos de solidariedade e amor mútuo, mas tanto para Jesus quanto para as personagens de Ensaio sobre a cegueira, existe a presença de grupos opositores. No caso do texto bíblico, os fariseus, saduceus, escribas, anciãos e outros, e em Ensaio sobre a cegueira o grupo dos ladrões, que constitui por assim dizer o grupo dos líderes antagonistas. Em ambos os casos, esses grupos antagonistas contribuem para intensificar o processo de sofrimento e dor das personagens.

As normas dadas aos grupos nos levam a estabelecer um novo elo entre os dois textos. Ao constituir seu grupo, Jesus atribui a ele uma missão: ("Vão e 
anunciem: O Reino do Céu está próximo. Curem os doentes, ressuscitem os mortos, purifiquem os leprosos, expulsem os demônios") (BÍBLIA SAGRADA, Novo Testamento, 1990. Mateus 10: 6-8, p. 1250). No manicômio, os cegos confinados também recebem instruções ("pedimos a atenção de todos para as instruções que se seguem, primeiro, as luzes manter-se-ão acesas, (...) sétimo, todos os restos deverão ser queimados (...)" (SARAMAGO, 1995, p. 50).

No paralelo das normas, observamos uma diferença. No texto bíblico, Jesus opera as normas para seu grupo, dando continuidade ao Seu projeto de vida, enquanto que no Ensaio sobre a cegueira, as normas partem do governo, na tentativa de resolver o problema da cegueira branca, procurando organizar o espaço que, não sendo suficiente, só faz gerar degradação e humilhação para as personagens. Tal como ocorre, por exemplo, no caso do estupro das mulheres, que consideramos o ponto culminante do sofrimento no manicômio, com características do grotesco, permeado de humilhação e dor. O estupro das mulheres pode ser comparado à humilhação de Cristo na cruz, momento ápice do seu sofrimento.

Após terem saqueado as camaratas, os cegos ladrões exigem as mulheres em troca de alimento, momento em que tem início o ritual sacrificial ("Quantas mulheres têm vocês aqui, perguntou um deles (...) Somos sete") (SARAMAGO, 1995, p. 173). O grupo composto por sete mulheres passaria pelas experiências mais cruéis, de total humilhação e escárnio:

Rapazes estas gajas são mesmo boas Vamos a elas que se faz tarde. (...) As mulheres todas estavam a gritar, ouviam-se golpes, bofetadas, ordens. (...) A mulher do médico (...) viu como o cego da pistola puxou e rasgou a saia da rapariga dos óculos escuros. (...) A rapariga dos óculos escuros não dizia nada, só abriu a boca para vomitar, com a cabeça de lado. (...) Meia dúzia de cegos avançaram de rebolão pela coxia, deitaram mãos à rapariga dos óculos escuros, levaram-na quase de rastos (idem p. 176177).

A cena descreve o martírio das sete mulheres sendo humilhadas, torturadas. Tiram-Ihes as vestes e a própria dignidade, no nosso ponto de vista. A cena descrita acima é o ápice do sofrimento em momento agudo e profundo. As 
mulheres usadas e abusadas pelos homens formam uma imagem carnavalizada da mulher e da sexualidade, através da exploração e animalização humana.

No texto bíblico, a descrição com o que ocorre com Cristo na cruz ("tiraram a roupa dele", "zombaram", "cuspiram", "bateram nele“, "teceram uma coroa de espinhos", "puseram a coroa em sua cabeça", "ensopou em vinagre, e deu para Jesus beber") (BÍBLIA SAGRADA, Novo Testamento, 1990. Mateus 27, p. 1278), indica o mesmo processo de escárnio e carnavalização das sete mulheres, o que nos aproxima do ritual sacrificial em Ensaio sobre a cegueira, praticado pelo grupo das sete mulheres, e no texto bíblico, por Jesus.

Todo o ritual das sete mulheres, servindo aos desejos eróticos dos cegos ladrões, constitui um dos momentos mais cruciais dessa peregrinação que, como na via-crúcis bíblica, leva à morte. O sofrimento de Cristo deu-se por todo seu povo; o sofrimento das mulheres, por todos os que necessitavam de alimento para sobrevivência no espaço do manicômio. Em ambos os casos, existe a presença do martírio, sofrimento de uns pela causa da coletividade, pela subsistência e sobrevivência dos "outros".

O ritual de purificação através do banho aproxima os dois textos. Após servir os homens, a cega das insônias morre; a mulher do médico lava-a, lava também a si própria e as outras mulheres, como que num ritual de purificação: “(...) queria lavar a cega das insônias (...) entregá-la purificada à terra" (SARAMAGO, 1995, p. 180). Fato semelhante ocorre com Jesus ao ser lavado com perfume por uma mulher: "Ela derramou esse perfume em meu corpo, preparando-me para a sepultura") (BÍBLIA SAGRADA, Novo Testamento, 1990. Mateus 26: 12).

Nos dois textos, o banho representa a purificação, o corpo lavado que será entregue à sepultura. No caso de Ensaio sobre a cegueira, todas as mulheres se banham feito um só corpo, a perfeição do cosmos; no texto bíblico, somente Jesus é banhado com o perfume.

Levantamos ainda um outro ponto de contato entre os dois textos: o destronamento que ocorre com as personagens. $O$ de Cristo ocorre quando recebe a coroa de espinhos, a vara e a zombaria ("Salve o rei dos judeus!"). Jesus 
torna-se um símbolo de rebaixamento, um rei ironizado, satirizado pela sua condição. Deus $O$ escolheu para salvar a humanidade dos pecados, fez uma aliança entre os homens, mas Jesus foi humilhado até o fim da vida. Em Ensaio sobre a cegueira, algumas personagens passam pelo processo de destronamento, como a mulher do médico, que, ao matar, sai temporariamente de sua condição de guia e benfeitora dos cegos e passa à de assassina, igualando-se aos ladrões (“Sim, matei-o eu, Porquê, Alguém teria de o fazer, e não havia mais ninguém", "se quiserem, outra vez servir-se de nós, Vai haver luta, guerra") (SARAMAGO, p. 189). Com essas declarações, a mulher do médico se assemelha agora aos cegos ladrões. No entanto, seu destronamento é temporário, porque não agiu de maneira inconsequente, mas sim, conscientemente, para salvar os demais das crueldades dos ladrões.

A coragem da mulher do médico em enfrentar os ladrões ("já matei, e tornarei a matar se for preciso") (SARAMAGO, 1995, p. 188), ao mesmo tempo que sinaliza um rebaixamento, pode ser lida também como um ato de resistência e heroísmo. Uma pessoa que se revela mais ativa que passiva em prol do "outro". Sua atitude em matar pode ainda nos aproximar do ritual sacrificial, o sacrifício que ela viveu, matando, para resgatar a dignidade dos cegos. Podemos encontrar esse mesmo ritual na personagem que atiçou fogo na camarata.

$\mathrm{Na}$ personagem que atiça fogo na camarata, vemos o papel de Cristo ao praticar o ritual sacrificial, sendo sua vida um sacrifício ao "outro", ao próximo. Em um momento de intensa dor e tristeza: "Então Jesus deu outra vez um forte grito, e entregou o espírito") (BÍBLIA SAGRADA, Novo Testamento, 1990. Mateus 27: 50 p. 1278), Cristo cumpre o que diziam as Escrituras ("O Filho do Homem vai morrer"), tal como um cordeiro imolado durante a Páscoa. Da mesma forma, a mulher que atiçou o fogo na camarata torna-se um "cordeiro imolado", não pelos pecados, mas pela vida dos cegos no manicômio, que de algum modo estavam atravessando seu martírio pessoal. Ao consumir-se nas cinzas, a mulher realiza o sacrifício de doar a própria vida para que os "outros" pudessem recuperar a sua ("já era o seu próprio corpo que estava a alimentar a fogueira") (SARAMAGO, 1995, p. 207). 
Nesse percurso da via-crúcis, procuramos dar ênfase à questão do sofrimento das personagens em ambos os textos - o bíblico e o Ensaio sobre a cegueira - apresentado através de rituais de sacrifícios, destronamento e carnavalização das personagens.

A respeito do sofrimento e do sacrifício de Cristo, encontramos em História da Filosofia (1956) uma explicação que nos ajuda a compreender a função da viacrúcis de Jesus e nos esclarece que a remissão dos pecados não termina em Cristo, mas prossegue na humanidade:

O contraste, a luta, a dilaceração permanecem mesmo depois da redenção perfeita do Verbo de Deus humanado, estas consequências do pecado original, a razão é que a Redenção remite (...) a culpa do pecado original e atual, mas deixa como pena o mal decorrente desses pecados (...) o homem acrescenta o que falta à paixão de Cristo (PADOVANl; CASTAGNOLA, 1956, p. 138).

Segundo nos parece, a exposição de Padovani e Castagnola, a respeito do sofrimento de Cristo estendido aos homens, justifica a peregrinação das personagens de Ensaio sobre a cegueira, e podemos refletir que o sofrimento no romance pode simbolicamente representar a continuidade da paixão de Cristo, pois sua trajetória sinaliza que ele "não realizou na sua pessoa o sacrifício redentor, mas também apontou aos homens este caminho, como sendo o caminho único para a salvação e a perfeição (...)" (idem, p. 141).

Em Ensaio sobre a cegueira, o sofrimento, ao que nos parece, está condicionado à restauração das vistas das pessoas, e o grupo escolhido sinaliza que isso ocorrerá com a experiência da paixão do grupo, pelas mais diversas experiências de dor e medo, que, inclusive, prosseguem após o manicômio ter sido consumido pelo fogo. As personagens se libertam e ganham as ruas da cidade, onde se seguirão os próximos passos da via-crúcis. 


\section{A queda - o terceiro percurso da via-crúcis}

Analisaremos o percurso das sete personagens nas ruas da cidade, que mais parece um labirinto. A sensação de se estar preso dentro de um labirinto, como no manicômio, estende-se às ruas e aos diversos lugares da cidade, provocando quedas durante a peregrinação. O motivo para esse percurso é a queda encontrada em Ensaio sobre a cegueira, que desvela um momento de intensa exaustão por parte das personagens.

Os espaços percorridos pelas personagens, como as ruas, a casa da rapariga, o supermercado e a igreja, podem ser tratados por lugares de passagem, segundo apontam os estudos de Marc Augé em Não-lugares Introdução a uma antropologia da supermodernidade (1994). Nessa obra, é apresentada a concepção de "lugar-antropológico" e "não-lugar": "Se um lugar pode se definir como identitário, relacional e histórico, um espaço que não pode se definir nem como identitário, nem como relacional, nem como histórico, definirá um não lugar" (AUGÉ, 1994, p. 73).

Procuraremos estabelecer um paralelo com as quedas de Cristo, apresentadas no texto bíblico durante sua peregrinação terrestre. Em ambos os textos as personagens caminham pressentindo a queda como metáfora da morte iminente. Para a contextualização desse percurso, partiremos do espaço da cidade percorrido pelas personagens de Ensaio sobre a cegueira:

\footnotetext{
Diz-se a um cego, Estás livre, abre-se-lhe a porta que o separava do mundo, Vai, estás livre, tornamos a dizer-lhe, e ele não vai, ficou ali parado no meio da rua, ele e os outros, estão assustados, não sabem para onde ir, é que não há comparação entre viver num labirinto racional, como é, por definição, um manicômio, e aventurar-se, sem mão de guia nem trela de cão, no labirinto dementado da cidade (...) (SARAMAGO, 1995, p. 211).
}

A mistura entre o comentário do narrador e a atitude dos cegos propõe um sentido labiríntico da linguagem. Em "Diz-se a um cego" e "tornamos a dizer-Ihe", a contaminação mútua de um dos sujeitos em um dos períodos gera uma certa 
dúvida sobre se alguém está falando com os cegos ou se é apenas um comentário do narrador.

A cena apresenta dois tipos diferentes de labirinto: primeiro, o manicômio, racional, limitado, que não obstante as múltiplas dificuldades, ainda oferecia meios de se guiar dentro dele, ao menos com mais facilidade ("não há comparação entre viver num labirinto racional, como é, por definição, um manicômio"); depois, o labirinto irracional, desmedido, sem fronteira ("aventurar-se (...) no labirinto dementado da cidade"). Ou seja, no manicômio havia fronteiras (cercas, muros, cordas), ao passo que na rua essa fronteira é abolida. De mais a mais, aumenta a dificuldade de os cegos se locomoverem na amplitude da cidade.

O adjetivo "dementado" anuncia a circunstância da cidade em processo de degradação, ou seja, os horrores do manicômio sendo estendidos às ruas e ganhando proporções globais. Viver na cidade, como antes da epidemia, parecia tarefa difícil para as personagens e, por isso, o grupo procurava meios e condições de sobrevivência em meio ao caos:

Ao longo da rua outros grupos apareciam, pessoas isoladas também, encostadas às paredes havia homens a aliviar a urgência matinal da bexiga, as mulheres preferiam 0 resguardo dos automóveis abandonados. Amolecidos pela chuva, os excrementos, aqui e além, alastravam na calçada (SARAMAGO, 1995, p. 217).

No trecho, é possível visualizar a extensão do problema da cidade. Tudo parado, como expresso em "o resguardo dos automóveis". As expressões "ao longo da rua", "aqui" e "além" nos dão a entender que o espaço, ligado ao anterior, se encontra totalmente degradado,. A intensificação da degradação possibilita as mais variadas quedas, nesse trajeto das personagens pelo caminho da via-crúcis, assim como Cristo vive as mais diversas experiências provenientes das quedas, ao longo de sua trajetória.

Em História da Filosofia (1956), Padovani e Castagnola argumentam que a revelação cristã fundamenta-se no "conceito de uma queda original do homem no começo da sua história, e também no conceito de um Messias, um reparador, um redentor" (p. 152). Segundo os filósofos, a queda de Cristo é proveniente do 
pecado "original do homem", que resultou no problema do "mal", e a queda de Jesus ocorreu em reparação e redenção do pecado original, ou seja, do mal.

A queda durante o percurso da via-crúcis de Cristo, conforme é interpretada pelos cristãos, apresenta três momentos diferentes. Em cada um deles, podemos perceber que a queda não é somente física, mas significa a perda da própria vida, como se Jesus estivesse num momento de crise e tensão que o colocava na situação do limiar da sua própria existência, cumprindo a vontade de Deus em sacrificar-se para a remissão dos pecados da humanidade.

Os textos que relatam as quedas de Cristo em sua peregrinação terrena, contemplados pelos cristãos, podem ser encontrados tanto no novo como no antigo testamento. Iniciamos as indicações desses momentos com 0 antigo testamento:

O Senhor Javé abriu meus ouvidos e eu não fiz resistência nem recuei. Apresentei as costas para aqueles que me queriam bater e ofereci o queixo aos que me queriam arrancar a barba e nem escondi o meu rosto dos insultos e escarros. O Senhor Javé me ajuda, por isso não me sinto humilhado; endureço meu rosto como pedra, porque sei que não vou me sentir fracassado (BÍBLIA SAGRADA, Antigo Testamento. Isaías 50: 5-7, 1990, p. 993).

Esse primeiro fragmento do livro de Isaías relata a primeira queda de Cristo. Nele, o profeta traduz as palavras de Jesus como se estivesse junto dele no trajeto da via-crúcis. Tudo indica ser a narrativa de alguém que acompanhou os passos de Cristo. Observamos que a humilhação de Cristo faz referência ao tratamento que Ele recebeu dos soldados, durante o trajeto rumo à sua paixão: escárnio, ultraje moral e físico. O segundo momento de queda se dá quando o profeta relata o sofrimento de Jesus, decorrente de sua aceitação do projeto que Deus teria para com sua vida:

Todavia, eram as nossas doenças que ele carregava, eram as nossas dores que ele levava em suas costas. E nós achávamos que ele era um homem castigado, um homem ferido por Deus e humilhado. Mas ele estava sendo transpassado por causa de nossas revoltas, esmagado por nossos crimes. Caiu sobre ele o castigo que nos deixaria quites; por suas feridas é que veio a cura para nós (idem, p. 995). 
As humilhações sofridas por Cristo podem ser entendidas como sinal de solidariedade e amor para com o outro ("Ele estava sendo transpassado por causa de nossas revoltas"), como salvador de toda a humanidade, o próprio cordeiro imolado em sacrifício pelo pecado cometido, desde Adão. Dessa forma, notamos que o sofrimento de Jesus estava ancorado aos pecados "alheios", ao "mal", e que somente o seu sacrifício renovaria toda a humanidade.

A terceira queda, também simbólica, encaminha o leitor para a consumação dos fatos que antecederam a crucificação:

Foi preso, julgado injustamente; e quem se preocupou com a vida dele? Pois foi cortado da terra dos vivos e ferido de morte por causa da revolta do meu povo. A sepultura dele foi colocada junto com a dos ímpios, e seu túmulo junto com o dos ricos, (...) (BÍBLIA SAGRADA, Antigo Testamento, 1990. Isaías 53: 8-9, p. 995).

O livro de Isaías relata os passos de Cristo que tratam da queda. Trata-se de um livro não só profético, mas também evangélico, ao citar tanto os evangelhos quanto os atos dos apóstolos que narram a vida de Cristo. A denominação utilizada por Isaías é "Servo de Javé". No novo testamento, atribui-se esse título a Jesus (idem, p. 947).

Além do livro de Isaías, as quedas de Cristo são narradas nos evangelhos e apresentam narrativas semelhantes. A primeira queda da via-crúcis ocorre, segundo os evangelhos, com o prenúncio de Cristo através das profecias do Antigo Testamento. Como podemos conjecturar a respeito, a primeira das quedas se refere ao destino de Cristo, que era a morte (sacrifício) revelada antes de sua vinda ao mundo:

O Filho do Homem vai morrer, conforme a Escritura fala a respeito dele (...) (BIBLIA SAGRADA, Novo Testamento, 1990. Mateus 26: 24, p. 1275).

A primeira queda, segundo os evangelhos, é simbólica e é representada pela profecia da morte do Filho de Deus. Tanto no antigo como no novo testamento, há uma ideia central referente à primeira queda, à profecia do 
sofrimento de Jesus. A segunda queda também é representada pelo prenúncio dos profetas antigos:

Então Jesus disse aos discípulos: "Essa noite vocês vão ficar desorientados por minha causa, porque a Escritura diz: `Ferirei o pastor, e as ovelhas do rebanho se dispersarão'" (...) (BIBLIA SAGRADA, Novo Testamento, 1990. Mateus 26: 31, p. 1275).

Observamos aqui, que a linguagem figurada ("pastor ferido", pastor é Jesus, ferido o seu sofrimento, as ovelhas seus discípulos e seguidores) dá sequência ao processo de queda, pelo qual Jesus está passando durante o trajeto de sua via-crúcis. Pode-se entender a ferida como a morte de Jesus figurada como queda.

Comparando os dois textos bíblicos, o antigo fica em torno do peso da cruz de Cristo, como se nela estivesse todo o pecado da humanidade ("eram as nossas dores que ele levava em suas costas"). No evangelho de Mateus, Cristo faz uma previsão de sua morte comparando-se a um pastor de ovelhas, essas que se dispersam quando o pastor não está no meio delas. Essa segunda queda justifica e completa a primeira, que trata da morte iminente de Jesus. A terceira queda, a que alude o texto bíblico, faz parte da via-crúcis. Trata-se de um momento de oração e profunda tristeza de Cristo, ao sentir que logo sua morte ocorreria:

Então Jesus foi com eles a um lugar chamado Getsemani. E disse aos discípulos: "Sentem-se aqui, enquanto eu vou ali para rezar". Jesus levou consigo Pedro e os dois filhos de Zebedeu, e começou a ficar triste e angustiado. Então disse a eles: "Minha alma está numa tristeza de morte. Fiquem aqui e vigiem comigo". Jesus foi um pouco adiante, prostrou-se com rosto por terra, e rezou: "Meu Pai, se é possível, afaste-se de mim este cálice" (...) ( BIBLIA SAGRADA, Novo Testamento, 1990. Mateus 6: $36-40$, p. 1275)

O fragmento destacado revela a angústia de Cristo, pouco antes de sua crucificação. Ao antever sua queda (morte) próxima, coloca-se como servo em atitude de humildade, de despojamento. Ao rezar, diz: "Contudo, não seja feito como eu quero, e sim como Tu queres" (idem, p. 1275). E assim, então, prossegue todo o processo de entrega e morte de cruz. 
No Antigo testamento (Isaías), a terceira queda é justamente a morte, e o mesmo ocorre no evangelho com a entrega de Cristo ao seu destino final. Neste momento, Cristo parece resistir ao seu destino ("Se possível, afaste-se de mim este cálice")(BÍBLIA SAGRADA, Novo Testamento, 1990. Mateus 26: 40, p. 1275); ele solicita a Deus que o livre desse momento doloroso, mas em seguida aceita seu destino.

Diante dos fragmentos destacados, podemos observar que as quedas de Cristo em Sua peregrinação terrena constituem uma metáfora, a perda da vida para a morte na cruz. Esses momentos são de intensa dor, tristeza e sofrimento. Cristo sente-se fragilizado com as acusações que antecedem seu martírio, em meio à negação de um (Pedro), a traição de outro (Judas) e o afastamento dos demais discípulos. Assim, podemos dizer que a queda e a experiência da morte, mesmo antes de ela ocorrer, é uma espécie de descida aos infernos e retorno dele, representada pela imensa tristeza que Jesus sente, ao saber de sua condenação ("Minha alma está numa tristeza de morte"). A profunda tristeza de Cristo revela o sentimento de fracasso e cansaço diante de sua acusação e morte iminente.

A queda física de Cristo possui a mesma intensidade dolorosa da queda metafórica. No Getsêmani (em hebraico lagar), Jesus distante dos discípulos saiu para orar e "prostrou-se por terra" (BÍBLIA SAGRADA, Novo Testamento, 1990. Mateus 26, p.1275), a queda física de Jesus foi uma vontade própria, embora sentisse as dores da crucificação aproximar-se.

Assim como Cristo experimentou a queda e ora, juntamente com seus discípulos, e também ora sozinho, as personagens de Ensaio sobre a cegueira parecem viver experiências semelhantes. As experiências de queda são visíveis na cidade e nos lugares que a compõem (ruas, casa da rapariga, igreja e supermercado).

O espaço da cidade em Ensaio sobre a cegueira é a representação máxima do mundo às avessas, fora de ordem, no caos, expressão de homogeneidade e da vida "não-oficial" (Bakhtin, 1987), onde não há nenhuma distinção de cor, sexo, profissão, credo político ou religioso. É um espaço onde tudo se mistura e forma a 
grande massa humana. Um espaço que não possui marcas históricas, de identidade ou relacionais, podendo, portanto, ser entendido como um "não-lugar" ou um lugar de passagem (Augé, 1994), se não the fosse dado um sentido diferente, como cenário de ações importantes na narrativa.

A cidade e seus lugares marcam o percurso em que ocorrem as quedas que, após a cegueira, forma um espaço de pleno caos: "As ruas estão desertas (...) Há lixo por toda parte" (SARAMAGO, 1995, p. 211).

Ao que indica a narrativa, trata-se de um imenso espaço, onde as personagens parecem desfilar rumo a algum lugar, ou a lugar nenhum, em busca de um reconhecimento de si mesmas e de seu meio. Elas vivem a experiência de um espaço desordenado, desprovido de qualquer sentimento de esperança ou de centralidade. Vivem numa espécie de "caos" espaço-temporal e existencial. Não há nele nenhuma diferença entre os espaços. As ruas, as lojas, o supermercado ou a igreja, tudo surge com as mesmas características: pessoas cegas por todos os lados, sofrendo, com fome, com medo, vivendo uma vida sub-humana, trágica.

Isso nos faz refletir nas palavras de Lynch (1997): “Estar 'perdido' na cidade remete a muito mais que à simples incerteza geográfica, trazendo consigo implicações de completo desastre" (LYNCH, 1997, p. 04).

O espaço da cidade em Ensaio sobre a cegueira, neste percurso da viacrúcis das personagens, nos parece de total desastre, a impossibilidade absoluta de se manter elos relacionais, sejam eles humanos ou espaço-temporais. O desastre é observado pela completa destruição e homogeneização dos lugares da cidade ("Há lixo por toda parte") (SARAMAGO,1995).

Ao designarmos a cidade como um espaço homogêneo, queremos apontar a presença de uma possível visão carnavalesca do mundo, proposta por Saramago.

A homogeneidade, por exemplo, é uma característica marcante na teoria da carnavalização literária, assim como na própria festa do carnaval, onde o mundo não apresenta diferença alguma. "Participa-se e vive-se a festa", como se não houvesse nenhuma distinção de sexo, cor, raça, profissão ou posição social. Tal como nos apontam as pesquisas de Bakhtin (1987) ao apresentar o histórico da 
visão de mundo na Idade Média. Percebemos, através de seus estudos, características carnavalescas em Ensaio sobre a cegueira, sobretudo, na presença de um mundo de ordem invertida das coisas, com a cidade, por exemplo, totalmente degradada na instabilidade gerada pela cegueira que atacou todos os cidadãos.

O primeiro momento em que nos deteremos, a fim de demonstrar as características carnavalescas, é o desfile do grupo dos "sete peregrinos" pela cidade, visualizado a partir do instante em que as personagens saem do manicômio.

A saída do manicômio aponta para um rumo que o grupo deveria percorrer: a cidade. No entanto, ao iniciar a caminhada as personagens percebem que 0 espaço fora do manicômio era semelhante ao espaço dentro dele, que a cegueira branca havia assolado toda a cidade, todo o país, não poupando ninguém, exceto a mulher do médico, como já sabemos.

As ruas estão desertas, por ser ainda cedo, ou por causa da chuva, que cai cada vez mais forte. Há lixo por toda a parte, algumas lojas têm as portas abertas, mas a maioria delas estão fechadas, não parece que haja gente dentro, nem luz (...) bateu no vidro, uma das sombras mexeu-se (...) Como está o mundo, tinha perguntado o velho da venda preta, e a mulher do médico respondeu, Não há diferença entre o fora e o dentro, entre o cá e o lá (...) (SARAMAGO, 1995, p. 211, 214, 233).

O fragmento acima traduz a ideia de homogeneidade entre o manicômio e a cidade, ambos repletos de sujeira, de morte, de cegueira; a cidade encontra-se em total desastre, acarretando as quedas das personagens.

Ao nosso olhar, a queda apresentada em Ensaio sobre a cegueira pode ser compreendida como uma metáfora da morte e, consequentemente, da incapacidade de organização e percepção espacial, que as personagens experimentam, de formas distintas, como uma profunda descoberta de si mesmas e do mundo.

Uma delas é através da homonímia com o quadro $A$ parábola dos cegos (1568), do pintor seiscentista Brueghel, o velho. 
Sobre este assunto, utilizaremos o artigo de Ribeiro (2007) ${ }^{17}$. Nesse artigo, a pesquisadora traça um paralelo entre a cegueira retratada em Ensaio sobre a cegueira e a cegueira retratada na pintura, apontando diferenças, semelhanças e relações entre as duas expressões de cegueira. Em suas palavras:

No primeiro plano do quadro do pintor seiscentista, há uma vegetação rasteira escassa, um solo de terra, irregular e acidentado, percorrido por um grupo de seis cegos. Em todos esses elementos percebemos a sugestão de instabilidade, de insegurança, de desamparo, de risco de acidentes mais ou menos graves. (...) O primeiro da fila já se encontra caído, de costas. (...) Uma espécie de bolsa, que carregava, está ao seu lado, no chão, e a alça, que a prendia ao seu ombro, está afastada do corpo sugerindo o impacto da queda. (...) A segunda figura do grupo encontra-se em pleno processo de queda (...) (Ensaio sobre a cegueira ou de Brueghel a Seraut, 2007, p. 01).

Ribeiro analisa minuciosamente o quadro de Brueghel e o processo de queda presente nele. No quadro, as pessoas apresentam um movimento como se estivessem caindo num efeito dominó. Uma após a outra entra no processo de queda, como se não existisse outra alternativa, já que não havia quem enxergasse, para conduzi-las pelo espaço.

Apesar das diferenças, em relação aos tipos de cegueiras apontadas pela pesquisadora, entre a pintura e o romance, os efeitos são semelhantes. "Os afetados pela enfermidade não podem se locomover e nem realizar as tarefas, com a eficiência de antes" (Idem, p. 3). Apesar de se tratar de diferentes tipos de cegueira, tanto as personagens do quadro como as do romance vivenciam a queda pela incapacidade de ver. Tal como na pintura, o romance apresenta a queda enquanto consequência da cegueira. Em ambos os casos, há uma fila de cegos que caem uns atrás dos outros, em uma difícil situação, na tentativa de sobreviver e superar a falta que o sentido da visão faz, não só individual como coletivamente:

(...) a situação para os cegos, era catastrófica, uma vez que, segundo a expressão corrente, não podiam ver aonde iam, nem onde punham os pés. Dava lástima vê-los esbarrar nos carros abandonados, um após o

\footnotetext{
${ }^{17}$ Artigo citado no capítulo 2 deste trabalho.
} 
outro, esfolando as canelas, alguns caíam e choravam (...) (SARAMAGO, 1995, p. 127-128).

O trecho destacado é parte da descrição da situação da cidade, após o incêndio no manicômio: uma total deterioração humana e espacial consequentemente, causada, sobretudo, pela desorientação da cegueira branca ("não podiam ver aonde iam, nem onde punham os pés"). Podemos dizer que a deterioração humana é conseqüência da espacial. Assim, as quedas sempre causavam impactos doloridos e intenso sofrimento às personagens, como expressados, sobretudo, nos três últimos períodos. Ao que tudo indica, a queda não podia ser evitada, produzindo um efeito catastrófico na peregrinação das personagens, tal como expresso na fala do narrador:

Exaustos, muitos dos cegos tinham-se sentado no chão, outros, ainda mais debilitados, deixaram-se simplesmente cair, uns quantos haviam desmaiado (...) (SARAMAGO, 1995, p. 212).

A exaustão extrema a que chegaram os cegos fê-los entregarem-se à queda. Havia os que ficaram sentados ("muitos dos cegos tinham-se sentado"), outros que tombaram como que para aliviar o cansaço ("deixaram-se simplesmente cair") e outros, ainda, que perderam o sentido e desmaiaram.

O processo gradativo que ocorre no fragmento destacado apresenta uma imagem dos cegos que caem sequencialmente, um após outro. Os vocábulos indefinidos que iniciam as orações explicitam este movimento de queda lenta e sequencial ("muitos", "outros", "uns"). Apesar de indefinidos, as palavras nos dão a ideia de diminuição do número dos cegos e, ao mesmo tempo, de movimento lento da cena. A imagem criada com a redução do número de personagens que caem sugere a lentidão do movimento que parte uma agitação quase geral ("muitos") que caem, prosseguindo por ("alguns") até a aparente lentidão ("uns").

A fala da mulher do médico: "Só estamos de passagem" (SARAMAGO, 1995 , p. 215), revela o caráter de um trajeto em curso. Desde que saíram do manicômio, as personagens parecem desfilar nos espaços da cidade e vivenciar novas experiências em cada um deles. Assim é nas ruas, na casa da rapariga, no 
supermercado e na igreja. O "estar de passagem" revela um ato transitório e não fixo e, por isso, a preocupação da mulher do médico em organizar seu grupo para que ele não disperse pelo espaço devastado das ruas da cidade:

(...) levantaram-se os que ainda estavam deitados, recolheram os pertences (...) como se partissem em expedição (...) um a um iam saindo da loja, a mulher do médico reparou que estavam bem abrigados, é certo que as cores das roupas não jogavam umas com as outras, que as calças ou eram tão curtas que deixavam as canelas à mostra, ou tão compridas que tinham de levar dobras em baixo (SARAMAGO, 1995, p. 217).

O trecho refere-se à cena em que os cegos saem do lugar onde esperavam o retorno da mulher do médico.

Na sentença "como se partissem em expedição", a comparação da saída da loja com uma expedição nos faz indagar se o grupo parte já com uma missão estabelecida. Mas não é bem assim. A partida ainda não tinha destino certo. Parece haver uma ironia subjacente nesse período, pois o grupo continuava perdido na cidade. $O$ ato de sair "um a um" indica a organização que os prepara para o "desfile", o que se justifica pela preocupação da mulher do médico, quanto às cores e os modelos de roupas que cada um estava usando (curtas, compridas, cores sem combinação). As ruas da cidade formam cenários desse percurso de queda da via-crúcis. Simbolicamente, elas podem estar ligadas às mudanças e às transformações no curso da vida das personagens (BAKHTIN, 2002).

Enquanto signo do destino, como a trata Bakhtin, a estrada sinaliza a existência de um cronotopo ${ }^{18}$ que define a vida, o caminho, a trajetória do herói.

No caso de Ensaio sobre a cegueira, as ruas (fazendo as vezes da estrada) podem ser tratadas também como cronotopo, mas de uma forma invertida na narrativa, pois as ruas desconhecidas causavam ainda mais tensão e desespero às personagens: "Vai, estás livre, tornamos a dizer-Ihe, e ele não vai, ficou ali parado no meio da rua" (SARAMAGO, 1995, p. 211).

O que deveria ser um destino, uma busca, tornou-se para os cegos a total desorientação, como se estivessem perdidos no espaço imenso da cidade. Não só

\footnotetext{
${ }^{18}$ Tratamos a respeito da designação desse vocábulo no capítulo 2 deste trabalho.
} 
o grupo que a mulher do médico guiava, mas todos os cegos que restaram, passam pela experiência da desorientação espaço-temporal e do desfile carnavalesco às avessas:

Não se orientavam, caminhavam rente aos prédios com os braços estendidos para a frente, continuamente esbarravam uns nos outros como as formigas que vão no carreiro, mas quando tal sucedia não se ouviam protestos, nem precisavam falar, uma das famílias despejava-se da parede, avançava ao comprido da que vinha em direção contrária, e assim seguiam e continuavam até ao próximo encontro. De vez em quando paravam, farejavam à entrada das lojas (...) depois prosseguiam o seu caminho, viravam uma esquina, desapareciam da vista, daí a pouco surgia dali outro grupo (SARAMAGO, 1995, p. 218).

No primeiro período do fragmento, há uma afirmativa de que os outros grupos também não se orientavam, estando todos perdidos ("não se orientavam, caminhavam de braços estendidos"). A desorientação era geral, não havia quem conseguisse se orientar na cidade.

No terceiro período, a comparação dos cegos às formigas reporta não somente aos movimentos contínuos e organizados desses insetos, mas há referência aos problemas que também acontecem no andar em fila: "Esbarravam uns nos outros como as formigas que vão no carreiro"(SARAMAGO, 1995) . Em geral esses insetos, têm um destino certo, no entanto encontram dificuldades na caminhada. A organização nos parece uma ironia do narrador, pois os cegos estavam, na verdade, errantes e sem rumo. Os verbos "prosseguiam", "viviam" e "desapareciam", marcam movimentos contínuos e firmes, contrastando com a insegurança dos cegos, de braços estendidos, ao mesmo tempo que sugere um desfile ("dali a pouco surgia dali outro grupo"). É como se um passasse e desse lugar ao outro, ou seja, um movimento de entrar e sair. Os advérbios "daí" e "dali" sugerem ainda a ideia simultânea de tempo e espaço, a possibilidade da estrada (rua) enquanto um cronotopo, segundo Bakhtin (2002), que se torna palco do grande desfile das personagens que parecem estar em busca de um destino certo.

Podemos pensar nos espaços da rua, do supermercado, da casa da rapariga e da igreja como "não-lugares"(AUGÉ, 1994). No entanto, ao contrário da sua definição de que nesses lugares não ocorrem ações, mas um hiato, em 
Ensaio sobre a cegueira, esses lugares se tornam basilares na composição da narrativa, apontando sempre e cada vez mais para a deterioração humana e espaço-temporal:

A mulher do médico voltou para junto dos seus, recolhidos por instinto debaixo do toldo duma pastelaria donde saía um cheiro de natas azedas e outras podridões, Vamos, disse, encontrei um abrigo e conduziu-os à loja donde os outros tinham saído (SARAMAGO, 1995, p. 217).

Enquanto abrigo dos cegos, a rua deixa de ser um lugar somente de passagem, para compor um cenário de ações importantes, como as caminhadas e quedas no desenrolar do percurso das personagens. Durante as caminhadas pela cidade e sem nenhuma orientação, a mulher do médico deixa os cegos num canto da rua e parte em busca de abrigo. Quando o encontra, retorna para buscá-los.

O abrigo encontrado era uma loja ("conduziu-os à loja"), ou seja, um lugar de passagem ou um "não-lugar", mais uma vez com uma funcionalidade fundamental para as personagens. Tornou-se a casa dos cegos por algum tempo.

O trecho expressa ainda a deterioração espaço-temporal ("saía um cheiro de natas azedas e outras podridões"). As duas últimas palavras nos dão a dimensão dessa deterioração. Através do pronome "outras" podemos entender a infinidade dessas "podridões", ou seja, a impossibilidade de precisar a dimensão da degradação espaço-temporal que, constatada nas ruas, estendeu-se a outros locais, como a casa da rapariga, o supermercado e a igreja. Em todos esses lugares, são nítidas as rupturas relacionais entre os indivíduos e seu meio, pelo fato de elas desconhecerem o espaço da cidade, que se assemelhava a um labirinto:

A mulher do médico vai lendo os letreiros das ruas, lembra-se de uns outros não, e chega um momento em que compreende que se desorientou e perdeu (...) está perdida. Deu uma volta, deu outra, já não reconhece nem as ruas, nem os nomes delas, então, desesperada, deixou-se cair no chão sujíssimo empapado de lama negra, e, vazia de forças, desatou a chorar (SARAMAGO, 1995, p. 226).

A cena retrata a mulher do médico em busca de alimento para si e para seu grupo. Ao encontrar um supermercado foi até o sótão, onde achou alimento. Mas 
ao retornar até onde havia deixado os companheiros percebeu que estava perdida ("já não reconhece nem as ruas, nem os nomes delas"). A mulher encontrava-se perdida como que num labirinto espacial, difícil de encontrar a saída.

A personagem encontra-se em total desespero, a ponto de cair ("deixou-se cair") no meio da rua. O verbo "deixou-se" expressa uma permissão da personagem para a ocorrência do ato, como se já não aguentasse mais o peso da cruz e se entregasse ao chão. A mulher do médico percebe então que não é somente o seu grupo que está perdido, mas todos os cidadãos:

Deixou de chover, não há cegos de boca aberta. Andam por aí, não sabem o que hão-de fazer, vagueiam pelas ruas, mas nunca por muito tempo, andar ou estar parado vem a dar no mesmo para eles, tirando procurar comida não tem outros objetivos, a música acabou, nunca houve tanto silêncio no mundo, os cinemas e os teatros só servem a quem ficou sem casa e já desistiu de a procurar (...) (SARAMAGO, 1995, p. 232)

$\mathrm{Na}$ oração "vagueiam pelas ruas", o verbo empregado na terceira pessoa do plural é um indicativo de que todas as pessoas da cidade estão sob a mesma condição, andando ao acaso, sem destino, sem rumo certo, errante pelo imenso espaço da cidade, desesperançados, desanimados diante da impotência devido à incapacidade de orientar-se em silêncio e sem vida. O caos somente é superado pela atitude da mulher do médico que, pela primeira vez, vai ao supermercado em busca de alimento.

No supermercado, a situação de total degradação encontrada nos outros espaços (como no manicômio e nas ruas) é a mesma, não há diferença entre estar na rua ou no supermercado ("Lá dentro o aspecto não era diferente") (SARAMAGO, 1995). A descrição espaço-temporal repete-se ("pelo meio, vagueiam os cegos, a maior parte deles de gatas") (idem).

A experiência vivida pela mulher do médico no supermercado nos aproxima dos estudos de Eliade (1989), que trata das experiências profundas vividas pelo indivíduo para uma possível "ressacralização" do mundo, pelas quais o indivíduo fica no limite da vida e da morte, passando por um tempo de provação, ou seja, vive o extremo de suas limitações no limite da própria existência: 
(...) pôs-se à procura de uma porta fechada que a pudesse levar à caverna dos tesouros, (...) lá dentro a mesma devastação, os mesmos cegos rebuscando o lixo. (...) Empurrou a porta corrediça e recebeu (...) duas poderosas impressões das coisas que são para comer (...) (SARAMAGO, 1995, p. 220).

O trecho descreve, inicialmente, os corredores do supermercado, os quais revelam a mesma devassidão das ruas da cidade, como por toda parte, com os cegos em busca de alimento.

A partir do momento em que a mulher encontra a porta de acesso ao porão do supermercado ("Empurrou a porta")(SARAMAGO, 1995) e constata a "escuridão profunda"(idem), ela relata o espaço do supermercado como um inferno. A escuridão profunda, o desconhecido espaço escuro, a total ausência de luz e de vida possibilita a personagem experienciar um tipo de cegueira escura, que faz sentido com o espaço vazio, sem condições de acolher as personagens. Além do aspecto escuro e sem vida, o estilo labiríntico do espaço identifica que a personagem está mais uma vez perdida e procura uma saída:

(...) tendo em conta o estado de debilidade em que se encontrava, deveria ver se iria ter forças para carregar com os sacos cheios e repetir o caminho todo onde viera, neste momento entrou-lhe no espírito um medo horrível o de não conseguir regressar aonde o marido estava à sua espera (...) haviam sido tantas as voltas que dera, o desespero paralisoua. (...) O corredor continuava deserto. (...) Estou a perder o juízo, pensou, e tinha razões para isso, a descer como ia por um buraco tenebroso, sem luz nem esperança (SARAMAGO, 1995, p. 221).

Ao avançar pelo porão, a personagem expõe o sentimento de medo diante do labirinto que percebera ser aquele lugar ("haviam sido tantas as voltas que dera"), que muito se parecia com a cidade. Quando decide retornar, encontra a saída e percebe que está perdida novamente. É como se, para a personagem, o mundo fosse formado de ruas, saídas e entradas que não a levavam a lugar algum.

Assim como estava perdida no supermercado, estava também perdida nas ruas: "A mulher do médico vai lendo os letreiros das ruas, lembra-se de um, de outros não, e chega a um momento em que compreende que se desorientou e se perdeu" (SARAMAGO, 1995, p. 226). 
Nesse momento em que a mulher do médico se vê perdida, comparada a um cego ("desorientou"), é como se o tempo e o espaço confundissem a serenidade e a racionalidade da personagem.

O tempo de provação vivido no supermercado coloca-a em conflito com sua própria consciência ("perdeu"). O verbo indica que não teria somente perdido o lugar, o caminho regresso, mas a própria consciência de si mesma. Outro momento de experiência no supermercado se dá, após longas caminhadas pela cidade, quando o grupo já estava em lugar seguro. Essa segunda experiência trata da degradação total dos elementos espaços-temporais e da degradação humana:

A claridade do dia iluminava até ao fundo o amplo espaço do supermercado. (...) É singular, disse a mulher do médico, (...) não percebo porque não há pessoas a viver. (...) Quando a mulher do médico abriu a porta, o cheiro, o cheiro tornou-se mais intenso, cheira mal mesmo disse o marido. (...) Avançou pelo corredor cada vez mais escuro. (...) Saturado do fedor de putrefação, o ar parecia pastoso. A meio caminho a mulher vomitou. (...) Um novo vômito retorceu-lhe o estômago. (...) O médico correu conforme pôde, tropeçou e caiu, levantou-se e caiu. (...) Quando saíram do corredor os nervos dela foram-se abaixo de golpe, o choro tornou-se convulsão. (...) Que terá sucedido, Devem ter dado com a cave, precipitaram pela escada abaixo à procura de comida, lembro-me de como era fácil escorregar e cair naqueles degraus. E se caiu um, caíram, todos (...) (SARAMAGO, 1995, p. 297-298).

Neste extenso fragmento, que relata o retorno da mulher do médico ao supermercado. Pela descrição o espaço escuro e tenebroso do porão tal como é descrito, sugere um sepulcro. Nele encontra-se um lugar como um cemitério, neste sentido está relacionado a um lugar deslocado.

Ainda neste fragmento, a presença dos constantes vômitos nos reporta às imagens grotescas (BAKHTIN, 1987), pavorosas, aqui subvertidas porque, ao invés do riso tem-se o choro ("o choro tornou-se convulsão"). A dor profunda da personagem, ao constatar o sepulcro que se tornou aquele lugar, que proporcionou as mais variadas quedas: as dos cegos que lá viviam, a do marido e a dela própria.

Os cegos caem gradativamente, num movimento único e contínuo. Neste fragmento, a queda das personagens parece insistente e implacável, causando a 
morte de alguns, testando a resistência de outros, como a do médico ("tropeçou e caiu, levantou-se e caiu"). Baseados nas quatro orações, duas formadas com a repetição do verbo cair podemos refletir a insistência do ato, que não parece uma escolha, mas imposição das condições humanas e espaciais. No trecho destacado, o médico, mesmo cego, consegue resistir à queda, levanta-se e ajuda a esposa a superar as provações, pelas quais estava passando ("segurou seu braço").

A queda da mulher do médico, ao que indica a narrativa, é decorrente de sua fragilidade diante da situação, pela qual estava passando. Nesse momento da via-crúcis, ela já sentia que perdia as forças, o corpo já não Ihe respondia como queria.

Neste sentido, o fragmento nos remete à experiência de Dante e Virgílio em A Divina Comédia, as quais as personagens saem em peregrinação e passam pelo inferno, pelo purgatório, até chegar ao paraíso. Ressalte-se a experiência vivida no Inferno, no Canto XI, onde eles passam pelo sétimo círculo e Virgílio explica a Dante o mau cheiro do sepulcro do Papa Anastácio (DANTE, 2003, p. 88). O sepulcro do Papa pode ser comparado ao sótão do supermercado, que exalava mau cheiro de matéria em decomposição, em estado de putrefação.

Mas a mulher do médico, apesar de sua fragilidade nesse percurso da peregrinação, insiste em prosseguir a caminhada e impulsiona o grupo, como vemos a seguir:

Reunidos no passeio, dispôs os companheiros em duas filas de três, na primeira colocou o marido e a rapariga dos óculos escuros, com o rapazinho estrábico ao meio, na segunda fila o velho da venda preta e o primeiro cego, um de cada lado da mulher. Queria tê-los a todos perto de si, não na frágil fila indiana do costume, que essa a todo o momento podia romper-se, bastava que se cruzassem no caminho com um grupo mais numeroso ou mais brutal, e seria como no mar um paquete a cortar em duas uma falua que se lhe tivesse metido à frente, conhecem-se as consequências de tais acidentes, naufrágio, destroços, gente afogada, inúteis gritos de socorro na vastidão (...) assim aconteceria com estes cegos, um cego aqui, outro além (...) (SARAMAGO, 1995, p. 248).

Na cena, ela organiza os cegos para uma caminhada e o modo como o faz nos remete à organização de um bloco carnavalesco ("dispôs os companheiros 
em duas filas") em plena avenida. A comparação feita com um acidente entre barcos ("seria como um paquete a cortar em duas filas uma falua") é uma indicação de uma possível catástrofe, representada pelas imagens grotescas sugeridas pelo narrador ("naufrágios, destroços, gente afogada, inúteis gritos de socorro na vastidão").

Como vimos em Ensaio sobre a cegueira, as quedas que se sucederam foram decorrência da cegueira branca, essa que desorientou as personagens, que tirou delas a capacidade de "ver" o outro e a si mesma.

A experiência de morte degradante não se dá somente no porão do supermercado. Cena semelhante encontra-se na ida à casa da rapariga dos óculos escuros, onde deparam-se com uma cena incomum:

Tinham passado já o corredor, o fedor tornara-se insuportável. $\mathrm{Na}$ cozinha mal iluminada pela escassa luz de fora, havia peles de coelho pelo chão, penas de galinha, ossos, e, sobre a mesa, num prato sujo de sangue ressequido, pedaços de carnes irreconhecíveis, como se estivesse sido mastigado várias vezes. (...) A velha movia-se com segurança (...) depois apontou a porta que dava para a escada de salvação (SARAMAGO, 1995, p. 237).

A visita à casa da rapariga traz diversos elementos da cena sugerindo um retorno ao supermercado ("corredor", "fedor", "escassa luz", "porta", e "escada"), cria uma imagem grotesca, exagerada, abundante, pavorosa. Os alimentos estão danificados, impuros, podres ("mastigados várias vezes"), causando o rejeição das personagens que lá chegaram.

O caminhar pelo corredor, à pouca luz, e a presença dos elementos grotescos apresentados no fragmento propiciam o tempo de provação (BAKHTIN, 2002) na vida das personagens. Novamente, vemos a deterioração humana e espaço-temporal na narrativa. Os elementos humanos e espaço-temporais encontram-se em situação de ruptura, sendo sustentados unicamente pela mulher do médico, que sempre encontra um meio de resistir às condições de subhumanidade com que se depara no decorrer da trama, mesmo quando se deixa cair ou desanimar. 
As experiências vividas no supermercado e a na casa da rapariga entrelaçam-se uma à outra, fazendo com que as personagens, aos poucos, tenham seus sentimentos modificados e, consequentemente, também a relação com "o outro" e com os elementos espaço-temporais. Após a ida à casa da rapariga, as duas conversam sobre os sentimentos de antes e de após a cegueira:

Dantes, quando víamos, também havia cegos, (...) os sentimentos em uso eram os de quem via, portanto os cegos sentiam com os sentimentos alheios, não como cegos que eram, agora, sim, o que está a nascer são os autênticos sentimentos dos cegos (...) (SARAMAGO, 1995, p. 242).

Durante o tempo da cegueira, as mudanças nos sentimentos das personagens transformam-nas, aos poucos, em pessoas mais conscientes de si mesmas e do mundo em que estão inseridas.

Todos os cenários aqui apresentados revelam as relações humanas e sociais estabelecidas na sociedade. Vive-se na cidade e, todavia, em condições que denotam mais a individualidade do que a coletividade, porém esse cenário é transformado gradativamente na medida que aumentam as necessidades das personagens os elos de solidariedade intensificam-se, o que sugere o surgimento de um novo modelo de sociedade.

Assim, observa-se uma ruptura quase que total das relações humanas num processo de queda contínua, às vezes lenta, mas de consequências profundas, como se constata nas experiências no supermercado e na casa da rapariga. $O$ caos tornou-se uma espécie de inferno vivido pelas personagens.

Como as experiências das personagens, nesta etapa, ocorrem em lugares parecidos com o inferno é importante ressaltar aqui, que o motivo inferno aparece em diversas obras, desde a antiguidade até os dias atuais. Ao analisar o inferno em A Divina Comédia, Aguiar (1988) apresenta a seguinte explicação:

O inferno é um mundo de loucura, de desrazão, de terror, um mundo ao contrário, do avesso. (...) No inferno se encontram as imagens do pesadelo, do bode expiatório, da dor, da confusão. O inferno é a concentração do conflito dramático. O princípio estrutural do inferno é a descida ao horror (...) seu princípio formal é o da irrupção de um tempo em outro tempo. (...) No inferno encontra-se uma paisagem desmedida 
para o humano (...) encontra-se uma visão dramática do humano (...) (apud Novaes, 1988, p. 321-322).

As definições de Aguiar acerca do inferno nos aproximam do caos humano vivido pelas personagens de Ensaio sobre a cegueira, sobretudo, pela mulher do médico, pois ela podia "ver" as imagens de horror presentes no inferno (supermercado e casa da rapariga). Desse modo, ela vive o mundo da "desrazão", do "terror", das coisas fora do lugar, do mundo em pleno desastre e "dramático", em sua generalidade. Os outros elementos (odores, contatos, sons) também tem efeito semelhante nos que não podem ver. Aliás não ver já é fator de terror, de horror que se intensifica com o que é dado pelos sentidos.

Ainda sobre a experiência da descida aos infernos, os estudos de Eliade (2001) indicam tratar-se de uma experiência de confronto e renovação, um tempo de provação dos iniciados: "(...) os iniciados descem ao fundo do abismo, a fim de afrontarem os monstros marinhos" (idem, p. 145).

Explica Eliade(2001), que a descida é uma experiência entre a vida e a morte, e entre a morte para a ressurreição, porque a descida é a experiência do morrer e do viver, ou seja, do ressurgir, uma espécie de provação para viver uma nova vida. Assim como ocorre nos rituais de iniciação, parece ocorrer também com as personagens de Ensaio sobre a cegueira que, após a passagem dessa experiência, encontram-se renovadas para uma vida transformada e revalorizada, pois confrontam-na consigo mesmas, seus medos e limitações, espécie de limiar entre a vida e a morte.

Após ter saído do supermercado pela segunda vez, a mulher do médico retoma o caminho. Sai do abismo, do espaço degradado imerso em lixo, habitado por cegos e mortos, assim como em quase toda a cidade. Ao sair encontra-se exausta, sem ter mais condições de prosseguir em sua peregrinação:

A mulher do médico mal podia arrastar os pés. O abalo tinha a deixado sem forças. Quando saíram do supermercado, ela, desfalecida, ele, cego. (...) Disse ao marido preciso recuperar forças, leva-me para além, Além, onde, Desculpa, vai-me amparando, eu digo-te, Que é, Uma igreja, se me pudesse deitar um pouco ficaria como nova (...) (SARAMAGO, 1995, p. 299). 
Na cena, a mulher do médico aparece "desfalecida", como se já não tivesse mais forças nem de se sustentar, de se amparar. Ao ver a igreja pede ao marido que a leve até lá; sua esperança era renovar-se, retomar as forças.

A igreja surge como forma de recompor as energias, um espaço que para a mulher poderia diferençar dos demais, por onde passara até agora, no percurso da via-crúcis. Mas, ao adentrar na igreja, a constatação é impressionante: ela possui as características idênticas de degradação dos outros espaços manicômio, casas, supermercado, ruas, avenidas e cruzamentos : "há imundície por toda parte") (SARAMAGO, 1995, p. 255).

Depois da descida aos infernos e a subida que levara a personagem à igreja, a impressão inicial é de que esse espaço poderia ser diferente dos demais, mas a fala do narrador remete a uma mesma situação, quando saem do manicômio. A oração, inclusive, é a mesma: "As portas estavam abertas de par em par". O narrador interrompe a descrição, justamente quando dizia anteriormente "os loucos saem". É como se o manicômio se tornasse o supermercado, as ruas e a igreja, ou seja, é como se todos os espaços participassem da mesma situação de total deterioração.

O espaço da igreja é descrito pelo narrador como "recinto sagrado" e "Templo", o que nos aproxima do Templo de Jerusalém na época de Jesus, que devido à comercialização em seu interior mais se parecia a um centro comercial. Em determinado momento, Ele chega a expulsar os comerciantes de lá : "Jesus entrou no Templo, e expulsou todos os que vendiam e compravam no Templo. Derrubou as mesas e as cadeiras dos vendedores de pombas" (BIBLIA SAGRADA, Novo Testamento, 1990. Mateus 21: 12, p. 1267). Não havia diferença entre a cidade de Jerusalém e o Templo, o qual era invadido por todas as pessoas. Podemos notar que o espaço sagrado era homogêneo em relação à cidade de Jesus. Em Ensaio sobre a cegueira, o espaço da igreja, subvertido, representa o Templo homogeneizado, semelhante aos outros lugares (ruas, supermercados, casa da rapariga). A situação encontrada na igreja é descrita da seguinte forma: 
Levantou a cabeça para as colunas esguias para as altas abóbadas, a comprovar a segurança e a estabilidade da circulação sanguínea, depois disse, Já me sinto bem, mas naquele mesmo instante pensou que tinha enlouquecido, ou desaparecida a vertigem ficara a sofrer de alucinações, não podia ser verdade o que os olhos the mostravam, aquele homem pregado na cruz com uma venda branca a tapar-lhe os olhos, e ao lado uma mulher com o coração trespassado por sete espadas e os olhos também tapados por uma venda branca, e não eram só este homem e esta mulher que assim estavam, todas as imagens da igreja tinham os olhos vendados (...) só havia uma mulher que não tinha os olhos tapados porque já os levava arrancados numa bandeja de prata (SARAMAGO, 1995, p. 301).

A cena descritiva da mulher do médico, enquanto observa as imagens, constata a homogeneização de todos os espaços. As imagens de olhos tapados representam, de certa forma, a cegueira estendida ao campo mítico, a "dessacralização" até mesmo do espaço sagrado. A esse respeito, diz Eliade (2001: "Para a experiência profana, o espaço é homogêneo e neutro" (p. 27).

Dessa forma, podemos examinar a igreja, enquanto espaço, como semelhante aos demais (manicômio, ruas, casa da rapariga e supermercado).

Ao entrar na igreja e ver as imagens de olhos tapados a mulher do médico pensa estar sofrendo "alucinações", o que indica que as "alucinações" vividas no supermercado continuavam na igreja. É como se a experiência do inferno se estendesse aos outros lugares; a igreja seria então a extensão das provações e confrontos, com a própria existência na vida da personagem.

A gradação presente na descrição indica a exaustão da personagem, que só é interrompida quando descreve a última imagem da mulher. Inicialmente utiliza as expressões "um homem" e "uma mulher". E no final utiliza o número dois para indicar a paridade das imagens, e a última descrição utiliza o número três. A utilização dos termos "homem" e "mulher" podem ser indicadores da homogeneização não só humana, mas também espaço-temporal.

A partir da ilustração dos momentos de queda na narrativa de Ensaio sobre a cegueira, podemos estabelecer um paralelo entre a queda na via-crúcis de Jesus, da qual retiramos algumas relações.

As quedas da mulher do médico ("abriu um espaço onde foi cair" e "atirouse no chão"), nos reportam às quedas de Cristo rumo ao Calvário: "Jesus foi um 
pouco adiante, prostrou-se com o rosto por terra" (BIBLIA SAGRADA, Novo Testamento, 1990. Mateus 26, p. 1275). O verbo "prostrou-se" indica a intencionalidade de Cristo ao cair, assim como a mulher do médico. Ambos vivem nesse momento um intenso esgotamento físico e mental. Esse gesto revela a exaustão das personagens e a degradação espaço-temporal e social, dentro da qual tanto Cristo como as personagens estavam vivendo, porque as personagens encontram-se exauridas, quase sem forças para vencer essa dolorosa passagem.

A exaustão e a entrega das personagens de Ensaio sobre a cegueira são muito parecidas com o texto bíblico. Cristo, sentindo suas forças se esgotarem, entrega-se à queda, também como forma de aliviar o cansaço e o desgaste ("Pai, em Tuas mãos entrego minha alma"). Quando cai pela última vez, ele se encontra em tão profunda dor e sofrimento, mesmo no momento de dor entrega-se a vontade divina: "Jesus foi pouco adiante, prostrou-se com o rosto por terra e rezou: 'Meu Pai, se é possível, afaste-se de mim este cálice. Contudo, não seja feito como eu quero, e sim como Tu queres'" (idem).

Já quase se arrastando pelo caminho, Cristo entrega-se à morte e se vê sozinho nos momentos mais fortes que antecedem seu martírio, ao contrário dos cegos que caem, coletiva e gradativamente, um após outro. Jesus cai sozinho, mas, assim como os cegos, resiste até o fim na peregrinação da via-crúcis, prosseguindo até o local onde encontraria a sentença que o esperava. Assim também as personagens continuam a peregrinação em busca de alimento e de sobrevivência, em meio ao caos instaurado por toda cidade.

As quedas ocorridas no caminho do supermercado nos remetem a uma das quedas da via-crúcis de Cristo, quando ele não suporta mais o peso da cruz e da dor e cai "(... eram as nossas doenças que ele carregava, eram as nossas dores que ele levava em suas costas") (BÍBLIA SAGRADA, Antigo Testamento, 1990. Isaías 53: 4-5, p. 1275).

A imagem da mulher do médico e a de Cristo assemelham-se no sentido de que, em ambos os casos, as personagens caem por amor e solidariedade ao próximo. Lutando contra suas próprias fraquezas, a mulher do médico solicita ajuda do marido: "leva-me para além" (SARAMAGO, 1995, p. 299). Cristo, 
sentindo-se imensamente triste, coloca-se despojado de si mesmo: "que seja feito como Tu queres" (BIBLIA SAGRADA, Novo Testamento, 1990. Mateus 28). Nos dois casos, os protagonistas revelam a fragilidade enquanto seres humanos cansados e abatidos.

A gradação das quedas em Ensaio sobre a cegueira (nas ruas, no supermercado ou na igreja) pode ser relacionada à gradação das quedas de Cristo que, não suportando mais o sofrimento, chega a prostrar-se com o rosto no chão, como um gesto de entrega ao momento doloroso pelo qual passaria em seguida (idem, 26: 38, p. 1275). Esse fato nos remete à imagem da mulher do médico quando, exausta pelo cansaço, se deixa cair no caminho doloroso que experimentara também na igreja ("Atreveu-se agora este a penetrar o sagrado recinto, a porta estava aberta... a mulher das lágrimas já entrou nem sei como poderá ela arrastar-se, vai murmurando ao marido uma só palavra, Segura-me... abriu um espaço onde se foi cair...") (SARAMAGO, 1995, p. 300).

Em ambos os textos, as personagens revelam, em suas ações, um movimento gradativo de queda que as fazem prostrar-se ao chão, como que solicitando ajuda, um pedido de socorro. Em relação à mulher do médico o pedido de ajuda é para o marido; no texto bíblico Jesus recorre a Deus.

Cristo sofria e pagava pelos pecados da humanidade. Suas quedas foram em decorrência de outrem, de sua entrega e amor ao próximo. Isso nos aproxima das personagens que se tornaram o centro da narrativa (o primeiro cego e sua esposa, o velho da venda preta, o garoto estrábico, o médico, a rapariga dos óculos escuros e a mulher do médico).

Todas tiveram as mais diferentes experiências de vida e morte no decorrer da narrativa, mas, sobretudo, a mulher do médico que, em boa parte da trama, sofre com a falta de visão que comprometeu toda a cidade. E ela, sendo a única que enxergava, carrega o peso da cegueira generalizada em suas costas (ajudava a curar as feridas, a enterrar os mortos, a lavar, purificar). Enfim, em tudo se aproxima da figura solidária e despojada que foi Jesus, inclusive quanto à impotência de ambos durante as quedas. Já não suportando estar no inferno do porão do supermercado, a mulher do médico solicita ao marido que a leve de lá; 
paralelamente, já não suportando a dor e o sofrimento, Cristo pede a Deus que afaste dele o cálice, mas aceita Sua missão pela vontade divina.

Outro ponto de contato entre os dois textos relaciona-se ao aspecto da cidade apresentada em cada texto. A cidade de Ensaio sobre a cegueira encontrase totalmente degradada nesse percurso da peregrinação ("Há lixo por toda a parte, algumas lojas têm as portas abertas, mas a maioria delas estão fechadas, não parece que haja gente dentro, nem luz (...)") (SARAMAGO, 1995, p. 211). A desestabilidade gerada pelo caos é revelada através da constatação da mulher do médico de que toda a cidade fora devastada.

Muito parecido com este cenário era a cidade de Jesus, Jerusalém: uma cidade feia, suja e malcheirosa, com uma paisagem monótona e triste. Seus córregos estavam sempre cheios de detritos e os pastos secos, devido ao calor e a pouca água. Nos dias quentes, o mau odor do capim apodrecido juntava-se ao cheiro de suor dos mercadores, dos animais e do lixo jogado nos vales, produzidos por desmoronamentos. Esses vales serviam de moradia aos infelizes, vagabundos e leprosos. Havia muito rebuliço e confusão. Os gritos dos mercadores ambulantes com suas mercadorias se misturavam à sujeira das ruas, aos excrementos dos animais e à exalação do péssimo esgoto mal distribuído. Os mercadores estavam sempre em rixas com os vendedores, disputando os fregueses para suas inúmeras mercadorias. A essa confusão, misturavam-se as súplicas dos mendigos e doentes. Assim, a cidade oferecia um aspecto desagradável e frio. (BÍBLIA SAGRADA - A palestina no tempo de Jesus, 1990).

Todo o contexto de deterioração humana e espaço social encontrado em ambos os textos é desvelado através do caos encontrado nos espaços de cada narrativa. No texto bíblico, o fato pode ser confirmado através do trecho: "O oficial e os soldados que estavam com ele, aguardando Jesus, ao notarem o terremoto ficaram com muito medo" (BIBLIA SAGRADA, Novo Testamento, 1990. Mateus 27: 54 , p. 1278).

O terremoto bíblico pode ser comparado ao caos estabelecido com a gradativa deterioração espaço-temporal em Ensaio sobre a cegueira ("O aspecto das ruas piorava a cada hora que ia passando. O lixo parecia multiplicar-se...) 
(SARAMAGO, 1995, p. 294). Aqui a cidade aparece totalmente destruída, como tendo sofrido um terremoto; tudo está fora de ordem, há deterioração por toda parte, pleno desastre. A degradação da cidade pode ser apreendida da mesma forma em ambos os textos, cenário de desolação e morte.

Com essa comparação pode-se notar que alguns dos dejetos criados na sociedade contemporânea são semelhantes aos criados em outras épocas. No entanto, em qualquer tempo a desorganização e a falta de conhecimento podem contribuir ainda mais para o caos, o qual, no caso das narrativas analisadas, promove a morte, produto da falta de esperança e exaustão das personagens no percurso da via-crúcis.

Nesse sentido, podemos conjecturar sobre a possibilidade de o espaço da cidade em Ensaio sobre a cegueira, assim como o do texto bíblico, serem espaços de passagem para as personagens, já que não emitem elos relacionais (Augé, 1994). Ao contrário, projetam a deterioração das relações humanas e espaçostemporais.

Podemos ainda refletir que, assim como o supermercado, a casa da rapariga e a igreja representam lugares de passagem que permitem aos personagens vivenciarem dois momentos importantes: o tempo do sofrimento infernal (morte, decomposição, putrefação, medo, isolamento, tristeza) e o tempo da renovação, através dos rituais de iniciação).

O Monte Calvário, no texto bíblico, pode, da mesma forma, representar um lugar de passagem que proporciona a queda de Cristo, momento ápice de sua paixão. Nele, Cristo vive experiências muito próximas das que viveram os sete peregrinos de Ensaio sobre a cegueira: morte, solidão, tristeza e medo, diante da passagem dolorosa eminente: "Meu Deus, meu Deus por que me abandonastes" (BIBLIA SAGRADA, Novo Testamento, 1990. Mateus 27: 45, p. 1278). Mas, pode ser considerado ainda como o lugar que sugere uma possível transformação na vida de Jesus, da morte para a ressurreição.

Esse trecho nos reporta à cena da mulher do médico ao se deparar com o medo e a solidão na saída do supermercado e na entrada da igreja. Medo e solidão aliviados com a presença do marido, que a ajuda ("O marido tomou-Ihe o 
pulso (...) depois fez um esforço para levantá-la”) (SARAMAGO, 1995, p. 300) e a faz recuperar-se da inconsciência que, por alguns momentos, havia tomado conta dela. Assim como a mulher do médico sente-se em situação de medo, Cristo também vive experiência semelhante, como deixa transparecer o texto bíblico, no momento em que ele se sente sozinho e impotente diante do sacrifício da morte.

Até aqui, percorremos a via-crúcis das personagens desde o primeiro caso de cegueira, onde o espaço parecia organizado (no cruzamento), depois no consultório, no hotel, no manicômio, nas ruas, na casa da rapariga, no supermercado e, por fim, na igreja.

Em todos esses espaços percorridos pelas personagens, a experiência vivida baseou-se, de certa forma, em um mundo degradado pela falta da visão e, consequentemente, pela ruptura das relações humanas e espaço-temporais, mas paralelamente através das experiências iniciáticas, em um mundo com possibilidades de renovação e transformação.

As mais dolorosas vivências no caos do manicômio, o imenso desfile carnavalesco pelas ruas da cidade, a experiência do inferno no supermercado e na casa da rapariga, e a constatação da homogeneidade absoluta dos espaços, inclusive os sagrados, como o da igreja, proporcionaram às personagens vivenciarem novas experiências de encontros, sofrimento, queda e possibilidades de renovação. Após esse longo percurso encontram, enfim, um lugar diferente que possibilita uma nova experiência para o grupo: a casa do médico. 


\section{A restauração da visão como sinal de reconstrução espaço-temporal - o fim da via-crúcis}

A experiência vivida na casa do médico, como o último percurso da viacrúcis das personagens de Ensaio sobre a cegueira, relacionando-o com a última etapa da via-crúcis de Cristo, narrada no texto bíblico.

No primeiro capítulo do nosso trabalho, percorremos os primeiros passos da via-crúcis, tendo em vista o tema encontro, que marca os dois textos.

No segundo capítulo, detivemo-nos no sofrimento ao longo da caminhada, ocorrido no espaço do manicômio, bem como na visão apocalíptica do mundo que revelou a deterioração humana e espaço-social de Ensaio sobre a cegueira, em paralelo com o sofrimento e a carnavalização da pessoa de Jesus na narrativa bíblica.

No terceiro capítulo, tratamos do espaço da cidade em processo de deterioração, tendo como base o tema queda e o conceito de carnavalização literária abordado por Bakhtin (1987) que representa o mundo às avessas, fora da ordem, em quase total ruptura das relações humanas e espaços-temporais.

Diferentemente dos capítulos anteriores, que apontam para a degradação e deterioração humanas e espaços-temporais, aliadas a um percurso de sofrimento, dor, queda e morte, neste capítulo, examinaremos uma possível reconstituição das relações humanas e, consequentemente, dos elementos espaços-temporais, que ocorrem a partir do momento em que a peregrinação do grupo toma o rumo da casa do médico:

(...) chegaram enfim à rua onde moram o médico e a mulher. (...) Ao vencer o último lanço da escada, antes mesmo de pousar o pé no patamar, já a mulher do médico anunciava, Está fechada. Havia indícios de tentativas de arrombamento, mas a porta resistira. O médico meteu a mão num bolso interior do seu casaco novo e tirou as chaves. Ficou com elas no ar, à espera, mas a mulher guiou-lhe suavemente a mão em direção à fechadura (SARAMAGO, 1995, p. 255-256). 
A experiência vivida pelas personagens nesse novo espaço sinaliza uma metamorfose no interior de cada uma delas. A chegada à casa do médico pode ser compreendida como uma espécie de elevação, de segurança ("a porta resistira"). A porta fechada era um possível sinal de que aquele seria um espaço diferente dos percorridos até então. A ação da mulher do médico em indicar "suavemente" a fechadura ao marido revela a tranquilidade que, de certo modo, todo o grupo sentia. Ao que parece, havia na casa do médico algo diferente, que seria revelado adiante pelo narrador.

Paralelamente a esse novo momento da via-crúcis das personagens de Ensaio sobre a cegueira, observamos que a narrativa bíblica apresenta algo semelhante, ocorrendo no trajeto da via-crúcis de Cristo. Para ilustrar esse momento de transformação, escolhemos o fragmento abaixo do texto bíblico, que narra o momento em que Ele sai com vida do sepulcro, três dias após ter sido sepultado:

\begin{abstract}
Depois do sábado, ao amanhecer do primeiro dia da semana, Maria Madalena e a outra Maria foram ver a sepultura. De repente houve um grande tremor de terra: o anjo do Senhor desceu do céu, e aproximandose, retirou a pedra, sentou-se nela. Sua aparência era como a de um relâmpago, e suas vestes eram brancas como a neve. Os guardas tremeram de medo diante do anjo, e ficaram como mortos. Então o anjo disse às mulheres: 'Não tenham medo. Eu sei que vocês estão procurando Jesus que foi crucificado. Ele não está aqui. Ressuscitou, como havia dito! (...) As mulheres saíram depressa do túmulo; estavam com medo, mas correram com muita alegria para dar a notícia aos discípulos. De repente, Jesus foi ao encontro delas, e disse: 'Alegremse!' As mulheres se aproximaram, e se ajoelharam diante de Jesus, abraçando seus pés. Então Jesus disse a elas: 'Não tenham medo. Vão anunciar aos meus irmãos que se dirijam para a Galileia. Lá eles me verão (BÍBLIA SAGRADA, Novo Testamento, 1990. Mateus 28:1-10, p.1279).
\end{abstract}

Como relata o evangelho de Mateus, no terceiro dia após Sua morte, Cristo ressuscitou. Quando as mulheres foram visitar a sepultura constataram que seu corpo não estava mais lá e, no caminho, viram-No diante delas. 
Esse episódio é tido como a ressurreição ${ }^{19}$ de Cristo. Após ter passado pela acusação, condenação, crucificação e morte, Ele ressurge transformado para uma vida nova. Estava tão diferente que as mulheres não O reconheceram, e Ele "foi ao encontro delas". Só então, elas O reconheceram e se alegraram, e em seguida saíram para contar aos discípulos o que havia acontecido.

Conforme narra o texto bíblico, o sepulcro era um lugar fechado, frio. Assim era o local que acolheu o corpo sem vida de Cristo, mas que, a partir da ressurreição, tornou-se um lugar transcendental e revelador de profundas transformações.

Cristo saiu sem ser notado pelos soldados que guardavam seu túmulo; nem mesmo as mulheres perceberam o que havia ocorrido. Para Ele, as mulheres eram suas mais fiéis seguidoras. Sem esperar que Jesus ressurgisse, elas permaneceram fiéis até no túmulo, certas de que o fim da história de Jesus teria chegado. Contudo, o texto bíblico traz um novo momento ao narrar a ressurreição de Cristo, quando ele então deixa o sepulcro diferente, transformado. A experiência de Cristo no sepulcro foi de renovação para a nova vida, revelada quando Ele sai sem ninguém perceber e caminha pela cidade.

Quando Jesus morre e seu corpo é encerrado no túmulo, tem-se a impressão de que o fim chegou, assim como, aliás, acreditavam os discípulos e as mulheres. Em Ensaio sobre a cegueira, após a experiência vivida em cada trajeto e a constatação de que todo o espaço fora degradado, o fim igualmente parecia ter chegado para as personagens, porém, do mesmo modo, algo diferente ocorre na vida delas quando chegam na casa do médico:

Foi, portanto a uma espécie de paraíso que chegaram os sete peregrinos e tão forte foi esta impressão, a que, sem demasiada ofensa do rigor do termo poderíamos chamar transcendental, que se detiveram à entrada, como tolhidos pelo inesperado cheiro duma casa fechada, noutro tempo teríamos corrido a abrir as janelas, Para arejar, diríamos, hoje o bom

\footnotetext{
19 “(...) Os evangelistas narram que Jesus trouxe de volta à vida a filha de Jairo, o filho da viúva de Naim e também seu amigo Lázaro: (...); no entanto, a ressurreição de Cristo na Páscoa é de outra ordem: não é um retorno à existência terrena, mas uma passagem a uma vida definitivamente arrancada da morte. A fé na ressurreição de Jesus é o pilar do cristianismo: (...)" (Fouilloux, 1998: 226).
} 
seria tê-las calafetadas para que a podridão de fora não pudesse entrar. A mulher do primeiro cego disse, Vamos sujar-te tudo, e tinha razão, se entrassem com aqueles sapatos coberto de lama e de merda, em um instante se tornaria o paraíso inferno. (...) Entraram pois descalços (...) (SARAMAGO, 1995, p. 257-258).

O fragmento revela que a casa do médico é, definitivamente, um lugar diferente dos demais (ruas, casa da rapariga, supermercado e igreja) percorridos pelas personagens, até esse momento da narrativa. Ele indica um "paraíso", ou seja, as personagens saíram do caos, da destruição, para adentrar num lugar harmonioso e feliz, tal como indicado no substantivo "paraíso". A expressão "sete peregrinos" nos ajuda a estabelecer a relação com o trajeto da via-crúcis, que propomos desde o primeiro capítulo deste trabalho. Reportamo-nos ao significado da palavra "peregrino" no dicionário de simbologia:

Símbolo religioso que corresponde à situação do homem sobre a Terra, o qual cumpre seu tempo de provações, para alcançar, por ocasião da morte, a Terra Prometida ou o Paraíso perdido (...) designa o homem que se sente estrangeiro dentro do meio em que vive, onde não faz outra coisa senão buscar a cidade ideal. O símbolo exprime não apenas o caráter transitório de qualquer situação mas o desprendimento interior, em relação ao presente e a ligação a fins longínquos e de natureza superior. (...) Pode-se notar, com relação ao símbolo do peregrino, as idéias de expiação, de purificação (...) o peregrino faz suas viagens na pobreza; coisa que corresponde à ideia de purificação. $O$ bastão ou bordão simboliza ao mesmo tempo a prova da resistência e o despojamento. Todas essas condições preparam para a iluminação e para a revelação divinas, que serão a recompensa no término da viagem. A peregrinação se assemelha aos ritos de iniciação: ela identifica com o mestre escolhido (CHEVALIER; GHEERBRANDT, 1999, p. 709).

Como aponta a definição, a palavra "peregrino" está ligada à busca da passagem de um estado (sujeira, caos, desorganização, desorientação) a outro (limpeza, paz, purificação). No nosso caso, é como se a casa do médico fosse um lugar sagrado, separando os estados de impureza, do estado de purificação: "Entraram descalços".

A palavra "peregrino" indica um "caráter transitório", ou seja, um momento de passagem e de sofrimento, que leva à transformação e que remete, ainda, ao "tempo de provação", para que, após o percurso de sofrimento e dor, os peregrinos cheguem ao "paraíso" e encontrem na casa "o centro do mundo", 
(CHEVALIER; GHEERBRANDT, 1999, p. 196) a imagem do paraíso, do "prêmio", propriamente, a que fariam jus após todo o sofrimento. Por conseguinte, a casa do médico, o "espaço sagrado", torna-se a recompensa da peregrinação das personagens.

Na palavra "transcendental" está expressa a conotação da experiência diferenciada vivida pelas personagens na casa ("poderíamos chamar transcendental"). A narrativa indica que o movimento suave, sereno, dos cegos fêlos sentir a diferença desse espaço, que se destacava de todos os outros ("detiveram-se à entrada"); eles ficaram junto à porta a sentir o cheiro da casa, como se ela os convidasse a viver uma nova experiência.

$\mathrm{Na}$ parada e na retirada dos sapatos na soleira da porta, as personagens parecem viver um ritual de entrada, como se um novo mundo thes fosse revelado. A respeito do exame da soleira da porta, recorremos aos estudos de Bakhtin (2002):

Qualificaremos ainda um cronotopo impregnado de intensidade, com forte valor emocional, como o cronotopo da soleira; (...) é o cronotopo da crise e da mudança de vida. A própria palavra soleira já adquiriu, na vida da linguagem (juntamente com seu sentido real), um significado metafórico; uniu-se ao momento da mudança da vida, da crise, da decisão que muda a existência. (...) Nesse cronotopo o tempo é, em suma, um instante que parece não ter duração (p. 354).

Como define Bakhtin, a soleira é o cronotopo da "crise", da "mudança" e da "transformação", ou seja, de uma vida no caos, na desordem, tal como revelada no manicômio e nos lugares percorridos pelo grupo na cidade (ruas, casa da rapariga, supermercado e igreja) e que, nesse momento, ganha então um novo sentido (de paz e harmonia), que não encontraram nos outros espaços.

$\mathrm{Na}$ soleira, o tempo não pode ser medido ou identificado, é um tempo que pode ser curto e imprevisível, não há como defini-lo ("detiveram-se à porta"). 0 verbo na terceira pessoa do plural não exprime nenhum tempo, pode indicar alguns minutos ou significar meses e anos.

A ação das personagens no último período do fragmento: "Entraram descalços", nos leva a refletir sobre a sacralidade do espaço em que estavam 
prestes a adentrar. Leva-nos também a recorrer aos antigos ritos de iniciação (Eliade, 1989) onde, para entrar num lugar sagrado, a pessoa devia deixar do lado de fora os sapatos, a fim de não levar impurezas para o novo espaço.

Na Bíblia, encontramos um relato do chamado de Moisés que diz: "Moisés, Moisés' e ele respondeu: 'Aqui estou!'” e Deus disse: "Não se aproxime. Tire as sandálias dos pés, porque o lugar onde você está pisando é um lugar sagrado." (BÍBLIA SAGRADA, Antigo Testamento, 1990. Exôdo 3: 4-5, p. 72).

Assim, podemos considerar a casa do médico um lugar central, um eixo estrutural na vida das personagens, onde possivelmente elas vivenciariam uma nova experiência de vida e, a partir daí, encontrariam o eixo da própria existência (Eliade, 1989, p. 37).

Os primeiros sinais de sacralidade do espaço surgem já com as personagens entrando descalças na casa. Em seguida, ao entrarem, tem início um outro sinal importante: o da limpeza dos móveis ("o médico percorria vagarosamente os móveis com as mãos, deixava-Ihe sinais na superfície, era a primeira limpeza que começava (...) (SARAMAGO, 1995, p. 258). Sem se dar conta, o médico inicia um processo de purificação, ao percorrer os móveis com as mãos, como que tirando a poeira, a sujeira, revelando a essência do móvel, da mesma forma que com todos os outros, ao tirarem os sapatos e as roupas:

A mulher do médico disse, Dispam-se todos, não podemos ficar como estamos, as nossas roupas estão quase tão sujas como os sapatos. (...) A mulher do médico recolheu as roupas deixadas no chão, calças, camisas um casaco, camisolas, blusões, alguma roupa interior, pegajosa de imundície. (...) A mulher do médico sentiu frio, lembrou-se dos outros, ali no meio da sala, nus (SARAMAGO, 1995, p. 258-260).

Nos fragmentos destacados, as personagens são apresentadas sem calçados e sem roupas, ou seja, despojados de toda sujeira alheia, como se a imundície do corpo fosse retirada junto com a roupa e os calçados, que foram trocados. Na manhã seguinte, veio a chuva, e então a mulher do médico aproveitou para lavar os sapatos, as roupas, as panelas e tudo o mais de que precisava ser retirada a sujeira ("agora teria água para lavar as roupas imundas, os sapatos nojentos") (idem, p. 265). Inclui-se aí o banho dela mesma ("despiu de 
golpe a bata molhada, e, nua (...) pôs-se a lavar as roupas, ao mesmo tempo que a si própria "(ibidem). Logo em seguida, as duas mulheres, a rapariga dos óculos escuros e a mulher do primeiro cego se juntam a ela ("Tirem a roupa que tem vestida (...) estão além três mulheres nuas, nuas como vieram ao mundo (...) três graças nuas sob a chuva que cai. (...) As mulheres já estão lavadas, agora é a vez dos homens) (SARAMAGO, 1995, p. 266-268).

A imagem da cena do banho das três mulheres sugere a das três graças da mitologia, pintada por vários artistas, dentre eles Carle Van Loon (1763).

Segundo Commelin (1997), as três graças na mitologia representavam em seu conjunto a luz, a alegria e o renascimento. Portanto, é possível que o banho das três mulheres seja um momento de purificação e harmonia das personagens com o cosmos. Elas podem estar representando a alegria, a harmonia e a fertilidade, um mundo purificado e harmonioso.

$\mathrm{Na}$ mitologia grega, as graças são conhecidas como "Deusas da Felicidade". São elas: Aglaia/Abigail, Euphrosyna e Thalia, personificando respectivamente o esplendor, a alegria e o desabrochar. Hesíodo, o poeta grego, sustenta em sua Teogonia, que as graças eram filhas de Zeus, o deus dos deuses, e de Eurynome, uma ninfa do Oceano. Hesíodo descreveu as carites (graças) - do grego "chari" - como jovens de belas faces, senhoras da fertilidade, do encantamento, da beleza e da amizade. Já Sêneca (IV a.C.) descreve-as como donzelas sorridentes, desnudas ou cobertas por tecidos transparentes, envolvidas pela generosidade. Os filósofos iluministas do século XV (Florença), por sua vez, como as três fases do amor: a beleza, o despertar do desejo e o alcance da satisfação, ou como símbolo da castidade. Às graças associava-se o que promove encantamento, prazer, satisfação, júbilo, deleite e fruição com a vida; por isso, acreditava-se que elas presidiam banquetes, danças, encontros sociais, enfim, ocasiões de emoções positivas (Commelin, 1997).

Toda a positividade que representam as mulheres no ritual do banho pode estar indicando uma nova visão de mundo, alicerçada sob o prisma da renovação e purificação, sinalizadas pela voz do narrador ao indicar as três graças da mitologia. 
Nesse sentido, podemos pensar numa possível reconstrução das relações humanas e espaços-temporais, ou seja, o homem na reconquista do seu meio, como relatam os estudos de Eliade (2001), a respeito do banho cosmogônico e a simbologia da água. Em suas palavras:

As águas simbolizam a soma universal das virtualidades, elas são fons et origo, o reservatório de todas as possibilidades de existência. (...) A emersão repete o gesto cosmogônico da manifestação formal; a imersão equivale a uma dissolução das formas. É por isso que o simbolismo da água implica tanto a morte como a renascença. O contacto com a água comporta sempre uma regeneração (...) <novo nascimento> (...) a imersão fertiliza e multiplica o potencial da vida (...) <segunda morte> do homem ou a morte iniciática do baptismo (...) a imersão nas águas equivale (...) a uma reintegração passageira no indistinto, seguida de uma nova criação, de uma vida ou de um <homem novo> (...) banhos rituais primaveris que trazem saúde e fertilidade (...) precede a criação (p. 139-140).

Essas reflexões de Eliade nos indicam que o banho está ligado à renovação, à possibilidade da criação ou da re-criação, portanto, a um novo nascimento.

É o que nos parece revelar os banhos que ocorrem em Ensaio sobre a cegueira nesse momento da narrativa. $O$ banho revela um espaço também transformado, como se fora a conquista do Paraíso que, para Eliade, está ligada à nudez ritual. Em suas palavras: "A nudez ritual equivale à integridade e à plenitude; o Paraíso (...) (imagem arquetípica do tempo). Toda a nudez ritual implica um modelo intemporal, uma imagem paradisíaca" (idem, p. 145).

Em outras palavras, a busca da renovação, da imortalidade, o nascimento do homem novo; é, inclusive, o que também ocorre com o banho dos homens representado pelo velho da venda preta: "O velho da venda preta despiu o pijama (...) depois (...) entrou na banheira. (...) Ajoelhou-se no fundo da banheira (...)" (SARAMAGO, 1995, p. 269). Seu banho foi o único relatado entre os homens, como se ele, por meio de sua sabedoria e velhice, representasse todos os outros.

Observamos que esse banho é feito por imersão, como se a personagem buscasse com esse ato as possibilidades de renovação, regeneração e obtenção de uma nova vida. 
Estabelecendo um paralelo entre o banho lustral das mulheres e o do velho, podemos pensar que, além da limpeza do corpo, o ato de ajoelhar-se seria um ritual de pedido de perdão ("ajoelhou-se no fundo da banheira"). Quase que the faltava água, enquanto as mulheres tinham seus corpos totalmente encharcados pela água da chuva.

O gesto do velho da venda preta sugere um pedido de perdão, talvez pela forma como o homem sempre agiu socialmente, sendo a personagem que carrega em si as decisões e reações diante do mundo. A imagem representada pelo velho pode ser a de um homem humilde, que se encontra tão frágil como todas as demais pessoas do universo. Ao sair do banho e retornar à sala, o velho está limpo e renovado: "Já temos um homem limpo e barbeado" (SARAMAGO, 1995, p. 269), como se todos os homens estivessem também limpos e purificados, renovados, enfim.

Ao tratar dos rituais de iniciação, Eliade (1989) explica que "o banho possui um caráter de renovação e renascimento" ( p. 124), uma espécie de ressurreição, preparando o homem para uma vida nova, regenerada, totalmente purificada.

Simbolicamente, o banho pode ainda significar que o sujeito está entrando em um processo iniciático, ou seja, que passa a fazer parte de um novo grupo. Nesse caso, o novo grupo é a nova sociedade, renovada a partir do sofrimento, durante a peregrinação dos espaços propostos na narrativa.

Dessa forma, tanto o banho das mulheres como o do velho pode ser interpretado como um ritual de purificação e de alcance de uma vida nova.

No cristianismo, o banho é símbolo de purificação e de renovação do corpo e da alma: "Quem já tomou banho, está todo limpo" (BÍBLIA SAGRADA, Novo Testamento, 1990. João 13: 10, p. 1375).

Quando João Batista inicia sua atividade profética, sua missão era a de batizar. Por meio do batismo, mediante o rito da imersão e emersão, as pessoas tornavam-se purificadas e renovadas de seus pecados (idem, Mateus 3: 5-6), o que caracterizava uma espécie de iniciação para uma nova vida. Significava a purificação dos pecados "nas águas da morte, a purificação através da água lustral, o retorno do ser às origens da vida. A emersão revela a aparição do ser em 
estado de graça, purificado, reconciliado com uma fonte divina de vida nova" (CHEVALIER, GHEERBRANDT, 1999, p. 119).

Assim, as personagens já se apresentam novas e preparadas para uma nova experiência de vida. $O$ banho que purifica é o mesmo que eleva o indivíduo ao patamar da experiência "transcendental", tal como propõe a entrada e os rituais realizados pelas personagens na casa do médico.

Após os rituais de limpeza e do banho, as personagens parecem então preparadas para uma nova experiência, conforme transcrito no fragmento a seguir:

Julgou o primeiro cego ter finalmente esclarecido esta dúvida quando de repente o interior das pálpebras se Ihe tornou escuro, Adormeci, pensou, mas não, não tinha adormecido, continuava a ouvir a voz da mulher do médico, o rapazinho estrábico tossiu, então entrou-lhe na alma um grande medo, acreditou que tinha passado de uma cegueira a outra, que tendo vivido na cegueira da luz iria viver agora na cegueira da treva, o pavor fê-lo gemer, Que tens, perguntou-lhe a mulher, e ele respondeu estupidamente, sem abrir os olhos, Estou cego, como se essa fosse a última novidade do mundo, ela abraçou-o com carinho, Deixa lá, cegos estamos nós todos, que lhe havemos de fazer, Vi tudo escuro, julguei que tinha adormecido, e afinal não, estou acordado, É o que deverias fazer, dormir, não pensar nisso, O conselho aborreceu-o, ali estava um homem angustiado como só ele sabia, e a sua mulher não tinha mais nada para Ihe dizer senão que fosse dormir. Irritado, já com a resposta azeda a sairIhe da boca, abriu os olhos e viu, Viu e gritou, Vejo. O primeiro grito ainda foi o da incredulidade, mas com o segundo, e o terceiro, enquanto mais, foi crescendo a evidencia, Vejo, vejo, abraçou-se à mulher como louco (...) (SARAMAGO, 1995, p. 306).

A cena mostra uma gradação e um processo de transição que ocorre nas vistas da personagem ("a brancura ofuscante dos seus olhos, depois, de repente, o interior das pálpebras se Ihe tornou escuro").

Nestes dois períodos, vê-se o oxímoro brancura e escuro, como um momento de transição da cegueira, a ponto de pensar que estava com outro tipo de cegueira ("acreditou ter passado de uma cegueira a outra"), ou seja, ao invés da cegueira branca, a escura ("treva", "vi tudo escuro", "julguei ter adormecido e afinal, estou acordado"). A personagem estava confusa, não sabia se estava dormindo ou não. Constata, por fim, estar acordada e, ao abrir os olhos, percebe que voltara a ver. 
Assim como o primeiro cego, todas as outras personagens recuperam a visão: a rapariga dos óculos escuros, o médico, enfim, toda a cidade e ao recuperarem a visão, deram a se conhecer uns aos outros.

O primeiro cego foi abraçar a mulher do médico e os outros do grupo. A rapariga dos óculos escuros e o velho da venda preta se viram pela primeira vez: "Olha-me bem, sou eu a pessoa com quem disseste que irias viver", ao que ela respondeu: "Conheço-te, és a pessoa com quem estou a viver" (SARAMAGO, 1995, p. 308-309). A partir do re-conhecimento de cada um, através da recuperação da visão, toda a cidade vive então um momento de transcendência: “(...) as ruas deviam estar cheias de gente, a multidão a gritar uma só palavra, Vejo (...)" (idem, p. 309, 310).

A recuperação da vista é a vida nova que as personagens estavam vivendo, a "ressurreição". A reestruturação das relações humanas e espaços-temporais ocorrem a partir desse momento, quando a cidade, a princípio tomada pela desordem e pelo caos, em contínuo processo de degradação e deterioração, começa a vislumbrar a possibilidade de reconstrução.

Com essa análise, acerca do último percurso da via-crúcis das personagens, podemos estabelecer o paralelo entre a via-crúcis de Cristo em seu último percurso.

Após três dias no sepulcro, Jesus sai às ruas revelando a sua ressurreição. Tão diferente estava, que nem as mulheres o reconheceram ("Jesus foi ao encontro delas") (BÍBLIA SAGRADA, Novo Testamento, 1990. Mateus 28: 9 p. 1279). Foi ao encontro delas e manifestou-se ressuscitado.

Essa experiência de transcendentalidade de Cristo pode ser comparada à recuperação da visão das personagens que, após entrarem no espaço sagrado (casa do médico) e iniciar os rituais de purificação (lavar roupas, sapatos e banharem-se), não só recuperaram a visão, mas também a própria essência interior, dando-se a conhecer uns aos outros.

No diálogo do velho da venda preta com a rapariga dos óculos escuros fica explícito que um dos fatores importantes no processo de reconstrução espaçotemporal e social é o conhecimento que cada indivíduo adquire de si mesmo e do 
mundo. É como se a visão desse às personagens a restituição da própria essência, revelando-se e dando-se a conhecer uns aos outros.

Esse último percurso da via-crúcis é o estágio da transformação profunda, o da transição de um estado (sofrimento, dor, angústia e morte) a outro (conhecimento, sabedoria, harmonia e vida). No caso de Cristo, de um morto a um ressuscitado ("Ele ressuscitou"); no caso das personagens, da recuperação da visão ("Vejo"), como se o mundo se abrisse às personagens, promovendo uma possível reconstituição do tempo e do espaço, reatando as relações humanas rompidas.

Em ambos os textos, o novo momento (transformação) pode ser lido como um momento de nova vida, de recompensa pelo sofrimento e pelas dores passadas. As personagens de Ensaio sobre a cegueira vivenciam experiências semelhantes às de Cristo após a ressurreição. Jesus sai do sepulcro em direção à cidade; as personagens de Ensaio sobre a cegueira vão às ruas, gritando "Vejo!". O caminho que seguem a partir de então são inversos. Cristo chama seus discípulos para um novo encontro: "Vão anunciar aos meus irmãos que se dirijam para a Galileia. Lá eles me verão. (...) Os onze discípulos foram para a Galileia, ao monte que Jesus tinha indicado" (BÍBLIA SAGRADA, Novo Testamento, 1990. Mateus 28: 10-16, p. 1279). Enquanto Cristo reúne seus amigos novamente, as personagens de Ensaio sobre a cegueira se dispersam, e cada uma sai à procura de sua casa:

\begin{abstract}
(...) a rapariga dos óculos escuros teve uma ideia, E se eu fosse pôr na porta da minha casa um papel a dizer que estou aqui, se os meus pais aparecerem poderão vir procurar-me, Leva-me contigo, quero saber o que está a acontecer lá fora, disse o velho da venda preta, $E$ nós também saímos, disse para a mulher o que tinha sido primeiro cego, pode ser que o escritor já veja, que esteja a pensar em voltar para a casa dele, de caminho tratarei de descobrir algo que se coma, Eu farei o mesmo, disse a rapariga dos óculos escuros. Minutos depois já sozinhos, o médico foi sentar ao lado da mulher (...) (SARAMAGO, 1995, p. 309).
\end{abstract}

Com a restituição da visão, cada personagem consegue ir ao encontro das casas, como que se lhe fosse restituída a própria essência da vida. Durante todo o processo, observa-se o movimento circular que permeia a narrativa. As 
personagens são retiradas de suas casas e, nesse momento, retornam a elas e também aos lugares por onde passaram (consultório, casa do primeiro cego, supermercado).

No sepulcro, Cristo entra morto e sai ressuscitado. Na casa do médico, as personagens de Ensaio sobre a cegueira entram cegas e sujas e saem enxergando e limpas. Entre o sepulcro onde Jesus foi enterrado e a casa do médico há algo "transcendental", algo que metamorfoseia as personagens por completo. Ao entrarem, não apresentavam sinais de luz, mas ao saírem se mostram transformadas, transfiguradas. São outros seres.

Outro ponto de contato que podemos estabelecer entre o texto bíblico e Ensaio sobre a cegueira é o ritual do banho, que parece-nos exercer uma função fundamental nas peregrinações.

O banho das personagens de Ensaio sobre a cegueira as prepara para um novo momento: o da lucidez, e ocorre de duas maneiras distintas. Ao que nos parece, o banho das mulheres projeta um mundo de alegria, harmonia e fertilidade, anunciado pelo narrador ("três graças nuas sob a chuva que cai") (SARAMAGO, 1995, p. 267).

A projeção de um novo mundo através do banho das mulheres contrasta com o banho do velho da venda preta ("entrou na banheira. A água era fria e era pouca", "ajoelhado na banheira como se estivesse a implorar misericórdia") (idem p. 269-270). A alegria e a descontração das três mulheres se opõem à ação do velho da venda preta que, conforme indica a voz do narrador, está num ritual de pedido de perdão, como que remindo-se de algum pecado.

Os dois rituais, juntos, nos propõem de alguma maneira a reflexão sobre 0 propósito do banho em renovar e humilhar-se, em reconhecer-se "pecador". A humildade e purificação contidas no ato do banho nos aproximam do ato do lavapés, que Jesus praticou com seus discípulos.

No evangelho de João é relatado que Jesus praticou um ritual de purificação com seus discípulos, antes de sua morte:

Então Jesus se levantou da mesa, tirou o manto, pegou uma toalha e amarrou-a na cintura. Colocou água na bacia e começou a lavar os pés 
dos discípulos. (...) Chegou a vez de Simão Pedro. Este disse: 'senhor, Tu não vais lavar os meus pés?" (...) "Se eu não o lavar, você não terá parte comigo. Simão Pedro disse: "Senhor, então podes lavar não só os meus pés, mas até as mãos e a cabeça". Jesus falou: "Quem já tomou banho, só precisa lavar os pés, porque está todo limpo" (BÍBLIA SAGRADA, Novo Testamento, 1990. João 13: 4-10, p. 1374).

Este fragmento extraído do evangelho de João indica que o ritual do banho praticado por Jesus revelou dois de seus ensinamentos: a humildade em lavar 0 "outro", deixando-o renovado, e a purificação dos pecados, um contínuo estar a serviço do próximo.

Os banhos realizados pelas personagens de Ensaio sobre a cegueira também sinalizam tais virtudes, as quais propiciam as transformações nos indivíduos.

Esses rituais ocorrem em outros momentos nos dois textos. Na Bíblia, quando Cristo é lavado com perfume por uma mulher, e em Ensaio sobre a cegueira, quando a mulher do médico lava a cega das insônias. Ambos trazem a mesma concepção, segundo entendemos, de humildade e de purificação. $\mathrm{Na}$ acepção cristã, o banho significa uma vida nova e fecunda, princípio da vida sem pecado (CHEVALIER, GHEERBRANDT, 1999, p. 119).

Dessa forma, podemos supor que, ao morrer, Cristo remiu os pecados da humanidade, que a partir de então estaria livre do pecado original. As personagens de Ensaio sobre a cegueira estariam da mesma forma preparadas para uma nova vida, fecunda, renovada e feliz.

O ritual do banho vivido pelas personagens pode ainda estar ligado ao "mito cosmogônico", uma viagem iniciática para se chegar às origens e conhecer a Criação. Ao apresentar um estudo a respeito do mito cosmogônico, Eliade (1989) nos dá recursos para compreender a relação do homem e sua origem:

A importância do mito cosmogônico centra-se no fato de que a sua repetição, pelo homem, recupera a sua primordialidade, e a sua totalidade. Porque na origem está a divindade, a perfeição. Ela é o único estágio de perfeição e, por isso, tem de ser periodicamente reiterada. Para reintegrar-se na perfeição sagrada. É a historia sagrada, sempre transitória, mas sempre recuperada pelos ritos (p. 97). 
Ao fim da peregrinação através dos rituais sagrados, como o do banho, por exemplo, nos ocorre pensar que, ao recuperarem a visão, as personagens de Ensaio sobre a cegueira, possivelmente, superaram a debilidade do desconhecido e passaram ao estágio do conhecimento e da reintegração do próprio caminho.

Através dos rituais sagrados, elas resgataram a revitalização da existência e as relações sociais e espaços-temporais, recuperadas simultaneamente no decorrer da via-crúcis.

O leitor, de certo modo, sente que o nível de degradação regredirá, à medida que se exercitarem valores como solidariedade, justiça e respeito, os quais foram corrompidos na sociedade, em decorrência de comportamentos sociais alegorizados.

No romance, isso se deu pela "cegueira branca". A reversão se dará também graças às experiências de ressacralização do mundo, ou seja, da experiência religiosa do homem em relação ao cosmos, pois só assim será superado o caos e reencontrado o equilíbrio e o centro da existência humana. Toda essa experiência pode estar ligada aos "rituais de purificação" e "de passagem" (ELIADE, 2001).

Nos dois textos, observa-se que, a partir da "restauração", as personagens, cada uma com suas particularidades, imprimem seus exemplos de renovação e transformação.

O fim da via-crúcis revela que o caos instaurado no espaço da cidade pode ser reconstituído a partir do momento em que são feitas experiências de purificação e regeneração. No instante em que recuperam a visão, as personagens saem do estado de cegueira e tomam o curso da própria vida. Com isso, finda a peregrinação e, consequentemente, a via-crúcis, o caminho do sofrimento, da dor, da queda e da morte, devemos ressaltar que nesse momento deu-se a conclusão de todo processo que apontamos durante o percurso: a simultaneidade sofrimento e regeneração por toda a via-crúcis.

Esse caminho dá lugar ao mundo onde as personagens de Ensaio sobre a cegueira se encontram mais conscientes de si mesmas e com plenas 
possibilidades de reconstruir as relações humanas e espaço-temporais. Estão, assim, renascidas para uma nova vida. 


\section{Considerações Finais}

Desde o início deste trabalho, propusemos a análise da desconstrução e reconstrução dos elementos espaço-temporais de Ensaio sobre a cegueira, com a caminhada errante das personagens pelos diversos espaços da narrativa, tendo em vista um possível paralelo da via-crúcis de Cristo, narrada no texto bíblico.

Além do texto bíblico, utilizamos como base teórica as pesquisas de Bakhtin sobre a teoria do romance, a análise dos cronotopos, a cultura da Idade Média, o estilo carnavalesco e imagens do grotesco. Utilizamos também os estudos de Augé, a respeito da diferenciação de "lugar-antropológico" e "não-lugar".

Para terceira base teórica, foram utilizadas as pesquisas de Eliade, que nos ajudaram a compreender os rituais de passagem (iniciação) e a experiência do espaço sagrado e profano. Estudos de Ribeiro e Alvarez foram substanciais para focalizarmos as complexidades subjacentes, em questões como a "cegueira branca" e o consequente caos instaurado no desenrolar da narrativa. Em Padovani e Castagnola (1956), encontramos subsídios para melhor compreender a vida e a missão de Cristo, através de uma visão filosófica do texto bíblico.

Dessa forma, procuramos um ponto de partida no percurso de Cristo em sua via-crúcis.

Partimos do último encontro com os discípulos e o primeiro encontro das seis personagens, no consultório médico (o primeiro cego, sua esposa, o médico, a rapariga dos óculos escuros, o garoto estrábico e o velho da venda preta), que mais tarde se juntariam à mulher do médico, formando o grupo dos "sete peregrinos", que percorreriam os mais variados espaços da narrativa (manicômio, ruas, supermercado, casa da rapariga, igreja).

Nesses lugares, viveram, de um lado, as mais cruéis experiências da existência humana (fome, dor, guerra e morte) e do outro a possibilidade de renovação, são lugares da experiência do sagrado e dos rituais de purificação (banho), de um novo sentido para a vida que já se anunciava, gradativamente, no sofrimento. 
Assim como a ressurreição de Cristo ocorre ao sair do sepulcro, a reconstituição das relações humanas e espaço-temporais ocorrem quando as personagens recuperam a visão.

No primeiro capítulo, tratamos, então, do tema encontro, como o propulsor da narrativa, como ponto de partida da trama, o primeiro passo da via-crúcis das personagens, bem como do texto bíblico e, é a partir dele, que se dá início ao grande impulso da vida das personagens: a constatação de uma cegueira branca, sem explicações científicas e os primeiros casos de cegueira - o primeiro caso de cegueira no cruzamento de uma rua, o caso do ladrão ao dirigir o carro roubado, da rapariga dos óculos escuros no hotel e do médico em sua casa.

Algo semelhante ocorre também no texto bíblico, pois Cristo, no último encontro com seus discípulos, prevê que Ele será entregue aos seus opositores (escribas, doutores da lei, fariseus e anciãos do templo), através da traição de um dos discípulos. Essa atitude é comparada à do ladrão de carros e os dois traidores têm um fim trágico, a morte. Em ambos os textos, o encontro desencadeia a via-crúcis, a de Cristo, pelo julgamento e condenação, e a das personagens, pela cegueira branca insólita.

Para examinar os primeiros espaços que aparecem em Ensaio sobre a cegueira, utilizamos os estudos de Bakhtin (2002), que apresentam a ideia do cronotopo do encontro, da estrada e da análise do romance de aventura e provações, pois traços desses conceitos aparecem na narrativa na primeira parte do percurso da via-crúcis.

A designação de "lugar-antropológico" e de "não-lugar", de Augé (1994), também foram utilizadas ao longo do primeiro capítulo e dos demais e nesse sentido, pudemos perceber que Saramago subverte algumas denominações teóricas e as contextualiza de forma diferenciada na trama, como por exemplo, apresentando o manicômio, que seria um lugar de passagem, portanto sem relações identitárias, como um lugar onde ocorrem ações importantes e basilares, na composição da narrativa (sofrimento, ritual do banho iniciático, com o banho das sete mulheres, o martírio das mulheres e a libertação dos cegos). 
O encontro, por exemplo, segundo os estudos de Bakhtin (2002), ocorre no cronotopo da estrada; no romance, ocorre em um consultório médico, lugar fechado de pouca transitividade.

Em relação aos "não-lugares", que seriam espaços não relacionais, não históricos e não identitários, preenchidos por um hiato, Saramago preenche com ações, inclusive basilares, na composição da narrativa, como no consultório médico, por exemplo.

Analisamos o encontro, tendo em vista o consultório médico, o cruzamento da rua, o hotel e a casa do médico, enquanto espaços com traços de organização, no contexto de uma cidade que indicava possível estrutura de relações humanas e espaço-temporais e que aos poucos foram revelados enquanto espaços do início de uma desestabilização, ao ser constatada a cegueira branca, insólita e desconhecida, inclusive das autoridades.

O encontro no consultório foi motivo de paralelo com o último encontro de Cristo, que também ocorreu na cidade, em um espaço fechado e que, a partir de então, deu início ao processo de desestruturação espaço-temporal representada pela peregrinação das personagens no caminho do sofrimento.

Procuramos desenvolver este tema no segundo capítulo deste trabalho, prosseguindo na via-crúcis das personagens, tanto do romance quanto no texto bíblico. Nesse percurso, foi observada a carnavalização das personagens e de suas ações, em ambos os textos, dentro de uma visão apocalíptica da existência humana (caos, morte, destronamentos).

O espaço apresentado nesse percurso, em Ensaio sobre a cegueira, é o manicômio, espécie de microcosmo do inferno ("És capaz de imaginar aonde nos trouxeram, Não, ela ia a acrescentar A um manicômio") (SARAMAGO, 1995, p. 48). É nesse espaço que a mulher do médico diz que o inferno prometido, então se iniciaria, pois, a partir das ações nele ocorridas, são reveladas características de carnavalização da condição humana, um processo semelhante que ocorre no percurso de Cristo, que nessa etapa de sua peregrinação, ao ser carnavalizado, humilhado, agredido física e moralmente, vive nesse momento um profundo sofrimento que o leva a perder suas forças ("Tiraram a roupa dele", "zombaram 
dele", "cuspiram (...) e bateram nele" (BÍBLIA SAGRADA, Novo testamento, 1990. Mateus 27: 28-31, p. 1277).

No texto bíblico, o sofrimento ocorre após a condenação à morte na cruz e a carnavalização da pessoa de Cristo. Em Ensaio sobre a cegueira, a condenação é representada, sobretudo, pelo grupo das sete mulheres que foram humilhadas, barbarizadas, uma delas chegando a morrer (cega das insônias), ou seja, chegando ao ápice do sofrimento, em prol da vida alheia, pela busca da sobrevivência, processo semelhante ao que ocorre com Cristo, que se entrega à morte, após o extremo sofrimento físico e moral.

Como base teórica, utilizamos os estudos de Bakhtin (2002) para o exame do romance de aventura e de provações, que aparece subvertido em Ensaio sobre a cegueira. Em sua análise, o teórico russo fala dos heróis e heroínas que aparecem no romance grego, que são "desafiadas e provadas sua dignidade, sua coragem, seu destemor" (idem, p. 230), e o mesmo processo nos parece ocorrer com as personagens de Ensaio sobre a cegueira, sobretudo, em relação à mulher do médico, que passa pelas mais doloridas experiências de vida e morte, em boa parte da narrativa.

Para a análise do tempo de provações, utilizamos ainda os estudos de Eliade (1989), com a experiência da descida aos infernos, que faz parte dos rituais de iniciação o que estava ocorrendo no manicômio com as personagens.

Assim como os iniciados experimentam o sofrimento até a morte, o mesmo ocorreu com as personagens, que só se libertam com a atitude de uma mulher que coloca fogo nas camas dos cegos ladrões. Dessa forma, deu-se início ao ritual de libertação através do fogo. O fogo aparece como um elemento importante para essa parte da narrativa, por ser um elemento de vida nova para as personagens.

No terceiro capítulo, nos detivemos na análise das ruas da cidade, em total deterioração ("não há água, não há eletricidade, não há abastecimentos de nenhuma espécie, encontramo-nos no caos, o caos autêntico deve ser isto" (SARAMAGO, 1995, p. 244), bem como do supermercado, da casa da rapariga dos óculos escuros, espaços que se assemelham ao inferno (morte, putrefação, 
aspecto grotesco), e da igreja, espaço sagrado, homogeneizado em sua essência, como os demais ("a igreja está cheia, quase que não se encontra um palmo de chão livre")(idem, p. 300).

Nesses espaços, são analisadas as quedas ocorridas durante as caminhadas, que revelam a total degradação humana e espaço-temporal em Ensaio sobre a cegueira e, paralelamente, o texto bíblico que relata as quedas de Cristo em seu percurso até o último suspiro já na cruz ("Jesus deu um forte grito e entregou seu espírito") (BÍBLIA SAGRADA, Novo Testamento, 1990. Mateus 28, p. 1278).

O motivo queda é um dos temas basilares na estrutura narrativa, tanto em Ensaio sobre a cegueira como no texto bíblico, aparece nos dois textos como imagem figurada e representativa da morte.

No romance, a queda é representada pelo homônimo do evangelho (idem, Mateus 15: 14) "Se um cego guia outro cego, todos caem" e, em certo sentido, as personagens de Ensaio sobre a cegueira vivem todos de uma cegueira (exceto a mulher do médico), que a cada um atinge de forma diferente.

No texto bíblico, as passagens que expressam a queda estão ligadas à solidão de Cristo pelo caminho. Ele vê que seus discípulos estavam cansados e abatidos, ele mesmo se sentia sem forças, por isso a queda durante e antes do percurso foi física e metafórica, simbolizando a perda total das relações entre Ele, seus amigos e a constatação de sua morte iminente.

Em Ensaio sobre a cegueira, o terceiro percurso da via-crúcis, que trata da queda, é percorrido pelas ruas da cidade já totalmente deteriorada, como constatam durante a caminhada. Para o exame desse trajeto, utilizamos as pesquisas de Bakhtin (1987), acerca da carnavalização literária e do estilo grotesco.

A caminhada dos cegos pela cidade se assemelha a um grande desfile às avessas, que nada tem de riso ou de liberdade, como o carnaval na Idade Média, mas de dor e sofrimento, ao perceberem que toda a cidade foi contaminada e se encontra em caos total, não havendo o que funcionasse na cidade. Os grupos de cegos mais pareciam seres errantes, sem destino. 
Nesse percurso, as ruas sujas e a cidade são vistas como um labirinto e marcam as grandes quedas, seguidas de imagens grotescas causadoras de pavor e medo, como a ida ao supermercado, à casa da rapariga e à igreja. Todos esses espaços se apresentam da mesma forma, homogeneizados. Em todos, existe a presença dos cegos, que se assemelham uns aos outros, assim como os espaços.

A banalização espacial nos remete à experiência do espaço sagrado e profano (Eliade, 2001), não havendo nenhuma distinção entre eles. Nesse sentido, todos os espaços da via-crúcis, apresentados até este momento, são espaços "profanados", que estão ligados a experiências dúplices de sofrimento, rebaixamento, de provação e de iniciação.

Para análise dos elementos espaço-temporais, utilizamos os estudos bakhtinianos e observamos semelhanças com a experiência de descida aos infernos de Dante e Virgílio em A divina comédia de Dante (1955), pois, ao que tudo indica, o espaço do supermercado é uma espécie de inferno, tal qual experimentam as personagens de Dante e Virgílio.

Nos três primeiros capítulos deste trabalho, analisamos os espaços (o cruzamento da rua, o hotel, o consultório médico, o manicômio, as ruas, o supermercado e a igreja) que foram degradando e formando um cenário caótico e desestruturado. Desestrutura também encontrada nas relações humanas e sociais.

Assim como Cristo cai diversas vezes em seu percurso, até entregar-se à morte, momento de profunda dor e humilhação, as personagens de Ensaio sobre a cegueira vivem momentos de quedas e dor, durante o percurso pela cidade $\mathrm{e}$ seus espaços e sentindo-se sem forças, sobretudo, a mulher do médico, que já não suportando a experiência do inferno vivida no supermercado e na casa da rapariga, se vê tão desfalecida que se entrega à dor, sendo guiada pelo marido ("A mulher do médico mal podia arrastar os pés. $O$ abalo tinha-a deixado sem forças. Quando saíram do supermercado, ela, desfalecida, ele cego (...) disse ao marido, "Preciso recuperar as forças, leve-me para além (...)") (SARAMAGO, 1995, p. 299). 
Em ambos os textos, as personagens são apresentadas desfalecidas, com suas forças quase extintas, a ponto de entregarem-se à queda. No caso de Cristo, ocorre a morte após a entrega; para as personagens de Ensaio sobre a cegueira a resistência na caminhada foi marcante, embora as quedas insistentes, até que encontram um espaço diferente de todos os outros, a casa do médico, que proporciona um novo rumo na peregrinação. No texto bíblico, esse novo rumo se dá com a morte de Cristo na cruz.

No quarto e último capítulo deste trabalho, apresentamos o fim da via-crúcis das personagens. Para isso, examinamos a casa do médico como um espaço sagrado, ou ao menos, com experiência do sagrado. Um lugar "transcendental", o paraíso para os sete "peregrinos", onde encontraram luz, limpeza, alimento, banho, purificação e uma vida nova, livre da sujeira e da imundície dos espaços anteriores, lugar onde ocorre as mudanças mais profundas nas personagens que recuperam a visão preparados pelo sofrimento.

Assim como Cristo ressuscitou e saiu do sepulcro, as personagens parecem ter vivido semelhante experiência.

A partir dos rituais de purificação, como o banho, por exemplo, as personagens deram-se a conhecer umas às outras e, enquanto no texto bíblico, Cristo prepara um novo encontro com seus discípulos, as personagens que recuperaram a visão saem e cada uma parte em busca de suas casas, num movimento circular da narrativa, ou seja, retornam, a partir de então, para as casas de onde saíram ao entrar no manicômio.

Para o exame do espaço da casa do médico, utilizamos as pesquisas de Bakhtin (2002), acerca do cronotopo da soleira que, para ele, representa o ponto de transição, de mudança e transformação na vida das personagens.

Para a explicação dos rituais de purificação (banhísticos, por exemplo), utilizamos as pesquisas de Eliade (1989), que relata que esse ritual é o da regeneração e da vida nova e quem os utiliza se prepara para uma vida transformada e renovada.

Chegando ao fim da via-crúcis das personagens e desse trajeto, pudemos apreender que o processo de desconstrução espaço-temporal se deu pela ruptura 
das relações humanas, em decorrência da cegueira e da reconstrução do espaçotemporal, que ocorreu após a nova vida que, a partir de então, as personagens conquistaram. Ao menos é o que sugere o fim do romance.

O termo via-crúcis, por nós utilizado, remete a um caminho da cruz, do sofrimento, mas também de possibilidade de renovação e regeneração de uma vida, modificada com alicerces bem definidos, como os valores de solidariedade, amor, justiça e dignidade.

Dessa forma, podemos tratar o romance Ensaio sobre a cegueira ou o trajeto da via-crúcis, que é o que nos propõe o doloroso percurso das personagens, como o trajeto de Cristo em sua via-crúcis, da maneira apontada no texto bíblico. Algumas diferenças são encontradas nas relações entre os textos, como por exemplo: o aspecto social.

$\mathrm{Na}$ época de Jesus, predominava a cultura religiosa ligada à política, por isso os grupos eram denominados "político-religiosos". Esses grupos eram formados por proprietários de terras, membros da elite, pequenos camponeses, funcionários da corte, leigos, sacerdotes, pobres e estrangeiros, das mais variadas procedências, conhecidos por saduceus, doutores da Lei (escribas), fariseus, zelotas, herodianos, essênios e samaritanos. Cada grupo tinha uma postura religiosa e política, por isso, muitos eram rivais e Cristo não fazia parte de nenhum deles. Quando necessário, advertia-os quanto a seus procedimentos ("Ai de vocês doutores da Lei e fariseus hipócritas! Ai de vocês, guias de cegos! (...) Irresponsáveis e cegos!") (BÍBLIA SAGRADA, Novo testamento, 1990. Mateus 27, p. 1270), e por isso foi detestado por esses grupos e, consequentemente, sofreu por ser um cidadão que denunciava as falhas de sua época.

O contexto que envolve o romance Ensaio sobre a cegueira é o de uma sociedade contemporânea, organizada com traços da modernidade. Composta por diversas organizações partidárias e políticas, com objetivos distintos, voltada mais para o consumismo, que para a religiosidade, essa sociedade é representada pela correria das pessoas que não podem perder tempo ("Os automobilistas, impacientes, com o pé no pedal da embreagem, mantinham em tensão os carros, avançando, recuando, como cavalos nervosos") (SARAMAGO, 1995, p. 11), pela 
pressa como coordenadora da vida das pessoas e que não deixa que elas percebam o mundo ao seu redor e podem, por isso, estarem dentro de um processo de cegueira, sem mesmo notar.

No decorrer deste trabalho, procuramos estabelecer um paralelo da viacrúcis das personagens de Ensaio sobre a cegueira, com a via-crúcis do texto bíblico.

A via-crúcis, segundo nossa reflexão e conforme nos apresenta o texto bíblico, pode ser a representação do sofrimento, da dor, queda e morte pela qual viveu Jesus em sua época, da mesma forma como as personagens do romance também passam pelo mesmo processo de sofrimento, dor, queda e morte.

Assim, constatamos que o percurso da via-crúcis pode ser vivido por pessoas diferentes e em tempos diferentes, como sequência da Paixão de Cristo (Padovani; Castagnola, 1956), e no entanto, em todos os casos, ela proporciona ao peregrino, ao final do percurso, uma vida nova, mais consciente do que a vivida antes da peregrinação.

Embora em tempo e contextos diversos, a via-crúcis pode ser repetida cada vez que alguém ou um grupo se mostre com sinais diferenciados dos demais cidadãos da sociedade, sobretudo, quando esses sinais são de solidariedade e justiça em relação ao "outro", ao seu próximo, como o grupo dos "sete peregrinos" e, em especial, a mulher do médico.

Dessa forma, podemos concluir nosso trabalho refletindo que, a cegueira apresentada no romance de Saramago pode ser entendida, metaforicamente, como a via-crúcis das personagens, a caminho de uma vida nova transformada pela lucidez e podemos considerar que a via-crúcis pode ser compreendida em dois momentos importantes.

O primeiro é a via-crúcis individual, que cada personagem vive a seu tempo a própria (o médico, que já não pode curar nem a si nem aos outros, o ladrão que rouba e morre, a mulher do médico que mata, para garantir a sobrevivência), da mesma forma como ocorre com Cristo, segundo apresenta o texto bíblico.

A outra é a coletiva, representada em Ensaio sobre a cegueira pelo grupo dos seis cegos e pela mulher do médico que, unidos, representam a via-crúcis da 
sociedade cega, perdida no espaço social, que não reconhece o real ou irreal, não distingue conhecimento da verdade ou da razão e que, na peregrinação, procuram o caminho da lucidez e do conhecimento.

A destruição das relações interpessoais e espaço-temporais, que ocorrem na trama de Ensaio sobre a cegueira, pode estar alicerçada sob o prisma da busca do Paraíso, tal qual nos apresentam os estudos de Eliade (1989). Este nos mostra como os povos, no decorrer da história, destruíam seus valores com o desejo de retornar às origens, como única forma de se chegar ao Paraíso, através dos rituais de iniciação, momento em que se vive a instabilidade do caos que é superada com a recriação do cosmo.

Ao final da peregrinação, após terem passado pelas mais variadas experiências (morte, destruição, sofrimento, queda), as personagens de Ensaio sobre a cegueira vivem a possibilidade do retorno da visão e encontram um mundo transformado e renovado em sua essência.

Todo o processo dolorido da via-crúcis das personagens de Ensaio sobre a cegueira e também vivido por Cristo, como relata o texto bíblico, nos aproxima do mito da recriação, que foi estudado, dentre outros estudiosos, por Alvarez (2008:135), que aponta a trama de Ensaio sobre a cegueira, como uma forma de retomar o mito através das três grandes simbologias: da cegueira, do caos e do batismo, da forma que mencionamos no decorrer deste trabalho.

O que nos ocorre na conclusão é que a destruição e reconstrução do espaço-temporal em Ensaio sobre a cegueira pode estar ligada ao mito da recriação, onde tudo é destruído, como no livro de Gênesis (cap. 8), quando algumas pessoas são poupadas (no caso, Noé e sua família), para que depois o mundo fosse reconstruído.

De uma forma mais radical, o que nos indica o texto bíblico é que a vida de Jesus encerra semelhante mito. Ele veio como filho do Homem e de Deus, formando a aliança de Deus com os homens, desempenhou seu papel de redentor dos pecadores, sofreu e entregou-Se como sacrifício, "o cordeiro de Deus", Sua queda foi como a destruição, mas Sua ressurreição denota a força de seu Pai (Deus), que venceu até mesmo a morte. 
De uma forma próxima da narrativa bíblica, em Ensaio sobre a cegueira, as personagens que percorrem unidas os percursos da via-crúcis nos aproximam de Jesus, em sua peregrinação terrestre, percorrendo o caminho da dor, do sofrimento e da queda.

Entretanto, ao final, após a destruição, dá-se início a um novo momento do percurso, que é a recuperação das vistas, como forma de recriação do mundo devastado pela falta de visão, que pode estar ligado à falta de conhecimento e entendimento, pelo qual passaram as personagens da cidade de Ensaio sobre a cegueira. Como pode ocorrer com indivíduos de qualquer sociedade.

A expressão Alegoria da caverna, definida no Dicionário de Filosofia (2006), contribui para uma possível conclusão desse trabalho:

No livro VII da República, Platão narra uma história que se tornou célebre com o nome de mito ou alegoria da caverna. Seu objetivo é fazer compreender a diferença entre o conhecimento grosseiro, que vem de nossos sentidos e de nossas opiniões (doxa), e o conhecimento verdadeiro, ou seja, aquele que sabe aprender, sob a aparência das coisas, a ideia das coisas. Numa caverna, cuja entrada é aberta à luz, encontram-se alguns homens voltados para o fundo, não podendo locomover-se nem virar as cabeças. Um fogo brilha no exterior, iluminando toda caverna. Entre o fogo e a caverna passa uma estrada, ladeada por um muro da altura de um homem. Na estrada, por detrás do muro, vários homens passam conversando e levando nas cabeças figuras de homens e de animais, projetados no fundo da caverna. Assim, tudo o que os acorrentados conhecem do mundo são sombras de objetos fabricados. Mas como não sabem o que se passa atrás deles, tomam essas sombras por seres vivos que se movem e falam, mostrando serem homens que não atingiram 0 conhecimento verdadeiro. Platão descreve o processo dialético através do qual o prisioneiro se liberta e, lutando contra o hábito que tornava mais cômoda sua situação de prisioneiro, sai em busca do conhecimento da verdade, passando por diversos sucessivos graus de conversão de sua alma, até chegar à visão da ideia de bem. Uma vez alcançado esse conhecimento, o prisioneiro, agora transformado em sábio, deve retornar à caverna para ensinar o caminho aos outros prisioneiros (p. 42)

O mito da caverna pode nos ajudar a concluir nossa pesquisa, primeiramente, pelas imagens ilusórias não captadas coerentemente pelos olhos, não pela falta da luz, mas porque os olhos dos prisioneiros estavam voltadas para dentro, como dos cegos. Por essa razão, não tinham o conhecimento da imagem verdadeira, só alcançada quando o prisioneiro passa por provações e 
contestações sobre o que estavam vendo e saem da caverna e fazem suas descobertas, do verdadeiro conhecimento, para então, retornarem à caverna.

O mesmo ocorre aos cegos que, ao recuperarem a visão, vão às suas casas, renovados, revigorados, felizes, como se estivessem saindo da prisão da cegueira branca e, possivelmente, encontram o conhecimento da verdade de si próprios e dos elementos espaço-temporais, através das mais diversas experiências vividas durante toda a via-crúcis pela qual passaram. 


\section{Bibliografia}

\section{Obras de Saramago consultadas}

SARAMAGO, José. Levantado do chão. São Paulo: Cia. das Letras, 1980.

. Memorial do convento. São Paulo: Cia. das Letras, 1992.

. O ano da morte de Ricardo Reis. São Paulo: Cia. das Letras, 1984.

. O Evangelho segundo Jesus Cristo. São Paulo: Cia. das

Letras, 1992.

. Ensaio sobre a cegueira. São Paulo: Cia. das Letras, 1995.

. A jangada de pedra. Lisboa: Editorial Caminho, SARL, 1986.

. Cadernos de Lanzarote - Diário III, 1996.

. Todos os nomes. São Paulo: Cia. das Letras, 1997.

. A caverna. São Paulo: Cia. das Letras, 2001.

\section{Sobre o autor}

ALVAREZ, Aurora Gedra Ruiz; LOPONDO, Lílian. O diálogo socrático como instrumento de construção da autoconsciência. In: Polifonia № 11: Periódico do 
Programa de Pós-graduação em Estudos de Linguagem do Instituto de Linguagem da UFMTS, p.33-41, Mato Grosso, Cuiabá, 2007.

BRIDI, Marlise Vaz. José Saramago: Nova visão de história. In. Anos de Renovação: Cadernos entre Livros - Literatura Portuguesa, p.84, São Paulo: Duetto, 2008

CARREIRA, Shirley. Entre o ver e o olhar: a recorrência de temas e imagens na obra de José Saramago. Atas do 60 Congresso da Associação Internacional de Lusitanistas, 1999.

FERREIRA, Sandra Aparecida. Da estátua à pedra. (a fase universal de José Saramago), 2004. Tese (Doutorado em Teoria Literária e Literatura Comparada). Faculdade de Filosofia, Letras e Ciências Humanas. Universidade de São Paulo, São Paulo.

IGNATTI, Ângela Silva. Tempo, espaço e autoconsciência, a construção da identidade em Ensaio sobre a cegueira, 2008. Tese (Doutorado em Literatura Portuguesa) Faculdade de Filosofia, Letras e Ciências Humanas. Universidade de São Paulo.

KOLEFF, Miguel, FERRARA, María Victoria(Ed.). IV Apuntes SaramaguianosJosé Saramago: el debate impostergable. Córdoba: EDUCC - Editorial de la Universidad Católica de Córdoba, 2008.

RIBEIRO, Raquel de Sousa. Ensaio sobre a cegueira ou de Brueghel a Seurat. In. LOPONDO, Lílian. (Org.) Saramago segundo terceiros. São Paulo: Humanitas FFLCH - USP, 1998.

SILVA, Teresa Cristina Cerdeira. José Saramago entre a história e a ficção: uma saga de portugueses. Lisboa: Dom Quixote, 1989 


\section{Geral}

AUGÉ, Marc. Não-lugares - Introdução a uma antropologia da supermodernidade. Trad. Maria Lúcia Pereira. Campinas, São Paulo: Papirus, 1994.

ALIGHIERI, Dante. A Divina Comédia. Trad. José Pedro Xavier Pinheiro. São Paulo: D.Giosa - e.Books-Brasil - Ind. Gráficas S/A-Atena Editora, 2003.

ARGAN, Giulio Carlo. História da arte como história da cidade. São Paulo: Martins Fontes, 1992.

BACHELARD, Gaston. A psicanálise do fogo. São Paulo: Martins Fontes, 1997.

A água e os sonhos: ensaio sobre a imaginação da matéria.

Trad.: Antônio de Pádua Danesi. São Paulo: Martins Fontes, 1997.

. A poética do espaço. Trad. Antônio de Pádua Danesi. São

Paulo: Martins Fontes, 2005.

BAKHTIN, Mikhail. Estética da criação verbal. Trad. Paulo Bezerra. São Paulo: Martins Fontes, 2003.

- Questões de literatura e de estética - a teoria do romance.

Trad.Aurora Fornoni Bernardini, São Paulo: Hucitec, 2002.

- A cultura popular na ldade Média e no Renascimento - o contexto de François Rabelais. Trad. Yara Frateshi Vieira São Paulo: Hucitec/Ed.da Universidade de Brasília, 1987.

- Problemas da poética de Dostoiévski. Rio de Janeiro: Forense Universitária, 1981. 
Esthétique et théorie du roman. Paris: Gallimard, 1978. (Bibliotèque dês idées).

BARROS, Diana Luz Pessoa de. "Dialogismo, polifonia e enunciação". In: BARROS, Diana Luz Pessoa de; FIORIN, José Luiz (Orgs). Dialogismo, polifonia e intertextualidade. São Paulo: Edusp, 1994.

BERMAN, Marshall. Tudo o que é sólido desmancha no ar: A aventura da modernidade. Trad. Carlos Felipe Moisés e Ana Maria L. Ioriatti. São Paulo, Companhia das Letras, 2007.

BRAIT, Beth (Org). Bakhtin, Dialogismo e Construção do sentido. Campinas, São Paulo: UNICAMP, 1997. . Bakhtin conceitos chave. 3eed. São Paulo: Contexto, 2006.

Bíblia Sagrada, Novo testamento. Trad. Ivo Storniolo. São Paulo: Edições Paulinas, 1990.

CALVINO, Ítalo. As cidades invisíveis. Trad. Diogo Mainardi. São Paulo: Cia das Letras, 1990.

CANDIDO, Antonio. Literatura e sociedade: estudos de teoria e história literária. São Paulo: Nacional, 1980. . O discurso e a cidade. São Paulo: Duas Cidades, 2004.

CANEVACCI, Máximo. A cidade polifônica. São Paulo: Nobel, 1997. 
CEIA, Carlos. E - Dicionário de termos literários. 2005. Disponível em: http://www2.fcsh.unl.pt/edt//verbetes/A/Conotopo. htm. Acessado em 15 de abril de 2009.

CHEVALIER, Jean; GHEERBRANT, Alain. Dicionário de Símbolos: mitos, sonhos, costumes, gestos, formas,figuras,cores, números. Trad. Vera da Costa e Silva. Rio de Janeiro: José Olimpio, 1999.

CLARK, Katerina e HOLQUIST, Michael. Mikhail Bakhtin. Trad.J.Guinsburg. São Paulo: Perspectiva, 1998.

COMMELIN, P. Mitologia Grega e Romana. São Paulo: Martins Fontes, 1997.

DICIONÁRIO Houaiss da Língua Portuguesa. Rio de Janeiro: Objetiva, 2001.

DURAND, Gilbert. As estruturas antropológicas do imaginário. São Paulo: Martins Fontes, 1997.

ELIADE, Mircea. Origens. História e sentido na religião. São Paulo: Perspectiva, 1989.

. O sagrado e o profano: a essência das religiões. São Paulo:

Edição Livros de Lisboa, 2001.

GIDDENS, Anthony. Modernidade e identidade. Trad.: Plínio Dentzien e Jorge Zahar. Rio de Janeiro: ISBN, 2002

FOUCAULT, Michel. História da loucura na ldade Clássica. São Paulo: Perspecitva, 1972. 
Microfísica do poder. Org. Roberto Machado. Rio de Janeiro:

Edições Graal, 1979.

FOUILLOUX, Danielle (et alii) Dicionário Cultural da Bíblia. Tradução de Marcos Bagno. São Paulo, Edições Loyolo: 1998

HALL, Stuart. A identidade cultural na pós-modernidade. 11. ed. São Paulo: DP\&A, 2006.

HUTCHEON, Linda. Uma teoria da paródia. Lisboa: Edições 70, 1985.

. Poética do pós-modernismo: história, ficção, teoria. Trad. Ricardo Cruz. Rio de Janeiro: Imago, 1991.

JAMESON, Frederic. Pós-Modernismo: a lógica cultural do capitalismo tardio. São Paulo: Ática, 2004.

JAPIASSU, Hilton; Marcondes, Danilo. Dicionário básico de Filosofia. Rio de Janeiro: Zahar, 2006

KAFKA, Franz. A metamorfose. Trad. Modesto Carone. São Paulo: Cia das Letras, 1997.

LINS, Osman. Lima Barreto e o espaço romanesco. São Paulo: Ática, 2000.

LYNCH, Kevin. A imagem da cidade. Trad.Jefferson Luis.São Paulo: Martins Fontes, 1997.

LYOTARD, Jean-François. A condição pós-moderna. Rio de Janeiro: José Olympio, 2002 
MATTA, Roberto da. A casa e a Rua. 4르. Ed. Rio de Janeiro: Afiliada, 1991.

MERLEAU-PONTY, Maurice. Fenomenologia da percepção. São Paulo: Martins Fontes, 1994.

MIRANDA, Wander Melo (Org.) Narrativas da modernidade. Belo Horizonte: Autêntica, 1999.

MOISÉS, Massaud. Dicionário de termos literários. São Paulo: Cultrix, 1978.

MOLES, Abraham. O kitsch. São Paulo: Perspectiva, 1975.

NOVAIS, Adauto (Org). O olhar. São Paulo: Cia das Letras, 1995

PADOVANI, H; CASTAGNOLA, L. História da Filosofia. São Paulo: Melhoramentos, 1956.

POULET, Georges. O espaço proustiano. São Paulo: Imago, 1992.

RAGACHE, Claude Catherine; PHILIPPS, Francis. A cavalaria: Mitos e Lendas. Trad.: Ana Maria Machado. São Paulo: Ática, 1993.

ROSENFELD, Anatol. Texto/ Contexto. São Paulo: Perspectiva, 1969.

SANTOS, Milton. A natureza do espaço. São Paulo: Edusp, 2006.

SARTRE, Jean Paul. O Existencialismo é um Humanismo. Trad. Vergílio Ferreira, 4를. Edisboa: Ed.Presença, 1978.

SILVA, Cibelle Celestino, MOURA, Breno A. A natureza da ciência por meio do estudo de episódios históricos: o caso da popularização da óptica newtoniana. In. 
Revista Brasileira de Ensino de Física: volume 30 ํำ-Depto de Física e Informática, Instituto de física de São Carlos, Universidade de São Paulo, São Carlos: Print Vesion ISSN, 2007, p.1-10.

WILLIAMS, Raymond. O campo e a cidade na História e na Literatura. São Paulo: Cia. das Letras, 1989. 
